Linköping Studies in Science and Technology

Licentiate thesis No. 1857

\title{
Exploring Process Management as a Means for Greening Road Freight Transport
}

Priscilla Navarro

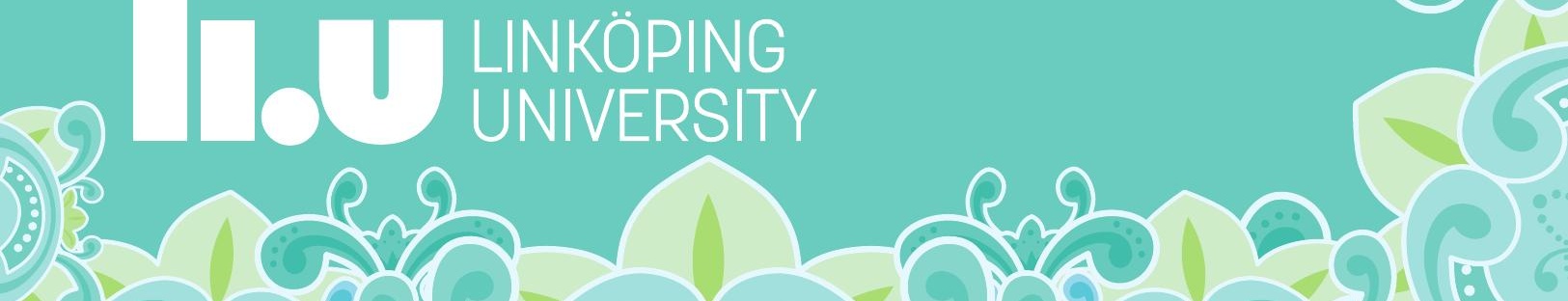


Linköping Studies in Science and Technology

Licentiate Thesis No. 1857

\title{
EXPLORING PROCESS MANAGEMENT AS A MEANS FOR GREENING ROAD FREIGHT TRANSPORT
}

\author{
Priscilla Navarro
}

2019

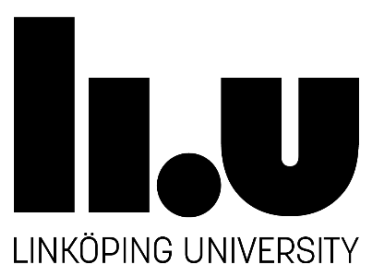

\footnotetext{
Logistics and Quality Management

Department of Management and Engineering Linköping University, SE-581 83 Linköping, Sweden
} 
Priscilla Navarro, 2019

"Exploring process management as a means for greening road freight transport"

Linköping Studies in Science and Technology, dissertations, No. 1857

ISBN: 978-91-7929-961-3

ISSN: 0280-7971

Printed by LiU-Tryck, Linköping 2019.

Distributed by:

Linköping University

Department of Management and Engineering

SE-581 83 Linköping, Sweden

Tel: +46 13281000 


\begin{abstract}
Research has proven that we need to reduce our environmental impact. Sweden has set a goal to become fossil free by 2045. The increasing amount of transport and the need to reduce its environmental effects has put pressure on the companies of the road freight transport sector. Therefore, this business sector needs research actions to find tools that will assist in the greening of its services and operations. My research is a contribution to these efforts from a managerial point of view.
\end{abstract}

Process management is a methodology taken from Total Quality Management (TQM) that has been used in several business sectors to improve business performance. Its process orientation and focus on customers allow companies to identify and satisfy the current and latent needs of their customers. Until now, TQM has targeted customer needs. However, it is experiencing a shift towards incorporating societal needs into the equation. Environmental sustainability is becoming a societal requirement for companies in all sectors. Hence, the purpose of my research is to explore the possibilities of using process management to support the greening of small and medium-sized companies within the road freight transport sector.

The frame of reference for my study is based on three well-established domains in academia and their intersections. These domains are: process management, road freight transport and environmental sustainability. I have used qualitative methods for my research. Specifically, I performed a case study at two medium-sized Swedish companies within the road freight transport business sector. The data collection methods involved document studies, observations and interviews at each case company. The case study was performed using an action research approach, which involved setting up meetings, seminars and workshops with each case company. Additionally, joint workshops were performed, which allowed me to observe and obtain results from the interactions between the companies. The analysis is presented for each case separately and then for their interactions. The results are compared with the existing literature from the three domains.

I based my research on three research questions. The first was intended to identify the principles and tools within process management that may be applied to road freight transport companies interested in implementing this methodology to enhance their environmental sustainability. I concluded that these principles were present in the companies and are needed for the implementation of process management. The tools included in this methodology can be associated with environmental initiatives performed by the companies in support of their greening.

The second research question refers to the benefits and challenges that companies in this business sector may face when implementing process management methodology. I conclude that most of the expected benefits of process management were confirmed. Additionally, a new benefit was observed: reducing the environmental effect of their services can interest current customers and attract new customers to road freight transport companies. The challenges identified during the case study include: resistance to change, lack of knowledge and resource allocation limitations. I also confirmed that a stepwise implementation of process management increases the likelihood of the success of the methodology. Hence, underdeveloped management systems are also a challenge when this methodology is used in freight transport companies.

The third and final research question involves the adaptations required for process management to enhance environmental sustainability in companies in this business sector. I refer to each of the challenges found and suggest certain requirements for the companies to apply this methodology. Clear communication from top management, the training of employees and the involvement of all employees are some of these requirements. Moreover, to incorporate the environmental aspects clearly, I suggest environmental efforts for each step in the implementation of process management. By including these efforts in the process maturity model, I conclude that road freight transport companies could use process management as a means of enhancing environmental sustainability. 


\section{Processledning för grönare godstransporter}

\section{Svensk Sammanfattning}

Forskning har visat att vi måste minska vår miljöpåverkan. Sverige har som målsättning att vara fossilfritt 2045. Den ökade mängden transporter och behovet av att sänka miljöpåverkan har en direkt påverkan på godstransportsföretag. Därför behövs forskningsåtgärder riktade mot dessa för att hitta verktyg som hjälper till att minska miljöpåverkan av dess verksamhet och tjänster. Min forskning är ett bidrag till dessa ansträngningar ur ett ledningsperspektiv.

Processledning är en metodik inom Total Quality Management (TQM) som har använts i flera branscher för att förbättra affärsresultat. Processorientering och fokus på kunderna gör att företag kan identifiera och tillfredsställa aktuella och latenta behov ifrån deras kunder. Fram tills idag så har TQM siktat in sig på kundbehov., men just nu pågår en förflyttning inom TQM mot att även inkludera samhällsbehov i ekvationen. Miljömässig hållbarhet håller på att bli ett samhälleligt krav för företag inom alla branscher. Därför är syftet med min forskning att utforska möjligheterna av att använda processledning som ett verktyg för att minska miljöpåverkan av små och medelstora företag inom godstransportbranschen.

Min studie baseras på tre väletablerade områden inom akademin och deras överlapp. Områdena är processledning, godstransporter och miljömässig hållbarhet. Jag har använt kvalitativa metoder för min forskning. Specifikt så genomfördes en fallstudie vid två medelstora svenska företag inom godstransportbranschen. Datainsamlingsmetoder som användes var dokumentstudier, observationer samt interjuver hos båda företagen. Fallstudien genomfördes med en aktionsforskningsapproach. Aktionsforskningen genomfördes som möten, seminarier och workshops hos varje företag. Dessutom genomfördes gemensamma workshops med företagen vilket gjorde det möjligt att observera och få resultat utifrån samspelet mellan företagen. Analysen presenteras för varje företag separat och därefter utifrån deras samspel, resultaten jämförs med existerande litteratur ifrån de tre områdena.

Min forskning utgår ifrån tre frågeställningar. Syftet med den första var att identifiera principerna och verktygen inom processledning som kan appliceras på godstransportföretag som är intresserade av att implementera metodiken för att öka sin miljömässiga hållbarhet. Jag drog slutsatsen att principerna från processledning fanns inom företagen och dom behövs för implementeringen av processledningen. Verktygen inom den här metodiken kan associeras med miljöinitiativ utförda av företagen och minska deras miljöpåverkan.

Den andra frågeställningen avser fördelarna samt utmaningarna som företag inom det här affärsområdet möter när de implementerar processledningsmetodiken. Min slutsats är att de flesta av de förväntade fördelarna med processledning bekräftas samt att ytterligare en ny fördel upptäcktes. En minskad miljöpåverkan av deras tjänster kan intressera nuvarande kunder och dra till sig nya. De identifierade utmaningarna från fallstudien inkluderar motstånd mot förändring, avsaknad av kunskap samt resursbegränsningar. Jag bekräftade även att en stegvis implementering av processledning ökar möjligheterna för att metodiken ska bli framgångsrik. Därför är också underutvecklade ledningssystem en utmaning för att kunna använda den här metodiken inom godstransportföretag.

Den tredje och sista frågeställningen berör de anpassningarna av processledning som krävs för att kunna öka miljömässig hållbarhet hos företag inom det här affärsområdet. Jag refererar till var och en av de utmaningar som hittades och föreslår vissa krav för företagen att applicera den här metodiken. Tydlig kommunikation ifrån ledningen, utbildning av anställda och involvering av alla medarbetare är några av dessa krav. Dessutom, för att integrera miljöaspekten tydligt, så föreslår jag miljöarbete för varje steg av implementeringen av processledning. Jag drar slutsatsen att godstransporföretag skulle kunna använda processledning som ett sätt att öka miljömässig hållbarhet. 


\section{Acknowledgements}

An African proverb says it takes a village to raise a child. Writing a thesis also requires a lot of support and help. I would like to take the opportunity to thank all the people that made this thesis possible.

First and foremost, I want to thank my supervisors, Peter Cronemyr and Maria Huge-Brodin. Thank you, Peter, for all the supervising meetings and for always inspiring me to become a better researcher. I have to specially thank you for the meetings you started with a taste of your music, I have actually started to like metal. Maria, thank you for all the times you agreed to my "just two minutes for a question" and for challenging me with your questions. I honestly believe they help me flourish as a researcher. You both have encouraged and guided me in every step of the way and for that I will be forever grateful. You have made this process fun and filled with learning experiences and I could not have asked for better supervisors.

I also want to thank Mats Abrahamsson for his contribution to my thesis. Mats, your questions, comments and suggestions were crucial for improving my thesis. I would also like to thank Lars Witell and Mattis Elg for taking the time and effort to read earlier versions of my thesis. Your input definitely helped me shape my thesis into what it is today.

This research would not have been possible without the help of management and employees from Haulier and Forwarder. Thank you for opening your doors to my research and allowing me to study your work. Your availability, honesty and engagement in the research project were key to achieving the results. Furthermore, I would like to thank the Kamprad Family Foundation for being the entity financing my research.

The LQ division is also part of that village that supported me in this journey. A work environment is fundamental for keeping the motivation and ambition at the top. You all have been role models of what a researcher should be and what teamwork is all about. You have thought me a lot, from what is consider as knowledge contribution to the importance of respecting the arrangements for fika. Thank you for all the enriching discussions, meetings and brown bags. Thank you, Kristina Dalberg for all the administrative help for the thesis and Jason for helping me with the refinements of the language in some parts of the thesis. But, not everything in life is work, so I should thank you all for the parties, after works and fun moments as well. A special thank you for my $\mathrm{PhD}$ colleagues and friends, both inside and outside the LQ division. Our lunches, fika and after works have made this experience more exciting and fun.

To my friends outside of the university, thank you for keeping me sane. I will be eternally grateful for being able to call you my friends and for listening to me in my moments of doubt and frustration. Most importantly I thank you for all the laughs and amazing moments shared.

To Mom and Dad, even when you are not here, I feel the need to thank you for always showing me that hard work gave the best results. Thank you for being the wind beneath my wings and for inspiring me to aim high. Caro, thank you for always making me laugh and giving me unconditional love. You definitely deserve a special thank you for the beautiful cover of this thesis, I love having something of yours in it. To the rest of my family and my Swedish family, thank you for your support, talks, laughs, love and for always reminding me what life is all about.

Chris, just thinking about thanking you and putting it into words brings tears to my eyes. You have been my rock through all these years and my cheerleader through this whole process. Your words of wisdom and encouragement led me to reach the goal. Alex, you are still too little to say anything, but your smile and love gave me a boost of energy every time I needed it. You and Dad are my inspiration and motivation. I love you!

Linköping, November 2019

Priscilla 


\section{Contents}

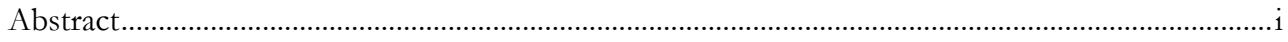

Svensk Sammanfattning ...........................................................................................................ii

Acknowledgements ..................................................................................................................ii

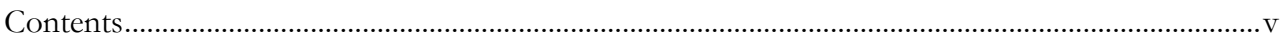

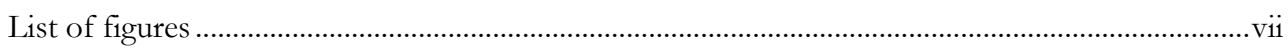

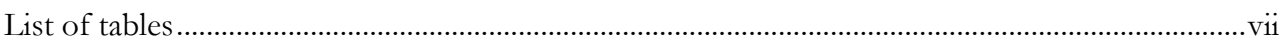

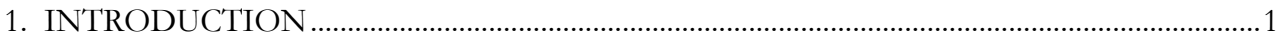

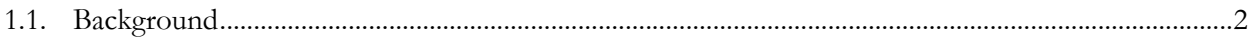

1.2. Positioning the research..............................................................................................................

1.3. The process management methodology ………………………............................................................

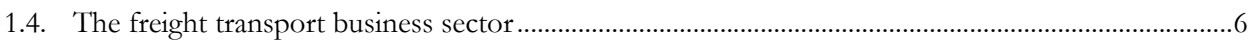

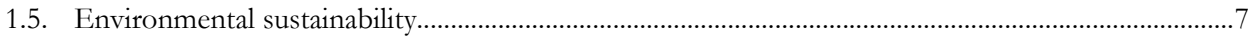

1.6. Purpose and research questions ..................................................................................................

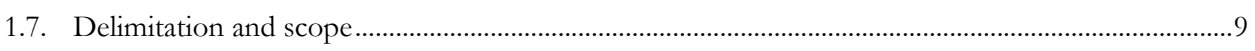

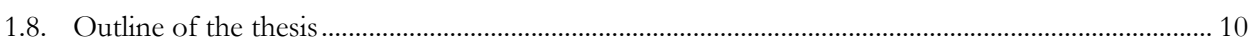

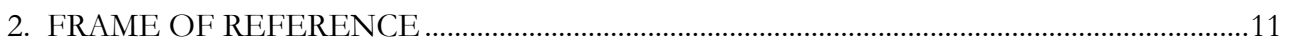

2.1. Total Quality Management........................................................................................................... 12

2.2. Process Management.................................................................................................................. 14

2.3. Process management in the road freight transport sector ................................................................. 22

2.4. Process Management for enhancing environmental sustainability ……........................................... 23

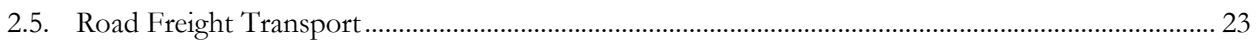

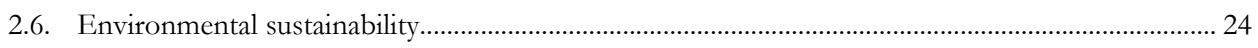

2.7. Environmental sustainability in the freight transport sector ........................................................... 25

2.8. Process management, environmental sustainability and road freight transport................................ 27

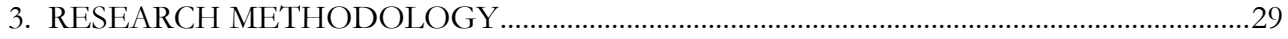

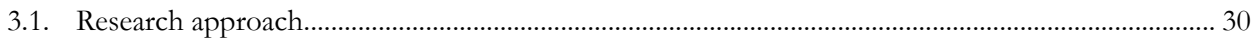

3.2. The origin of the thesis: the research project............................................................................... 30

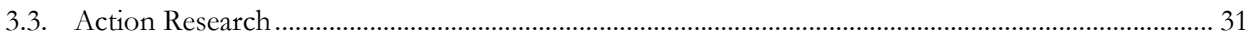

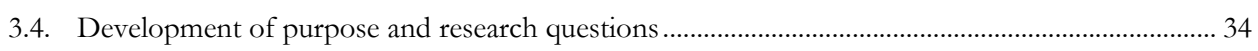

3.5. My contribution to the appended papers .......................................................................................... 34

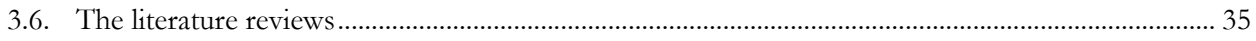

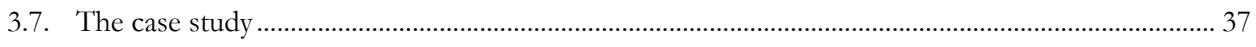

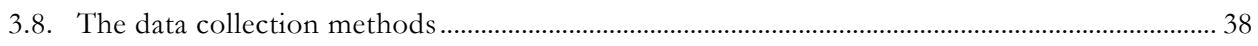

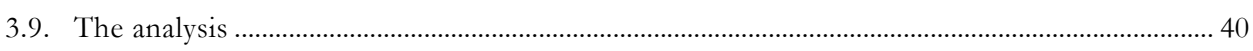

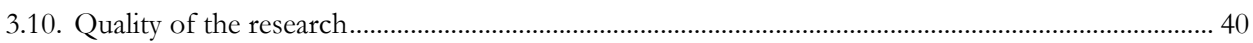




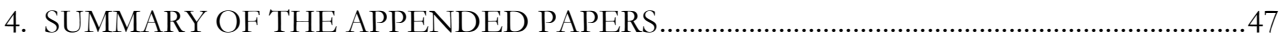

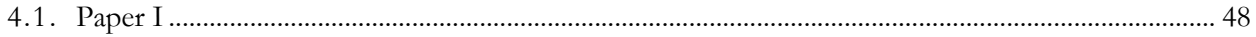

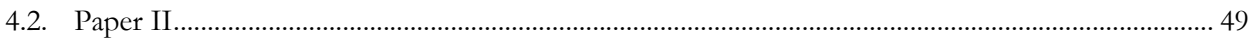

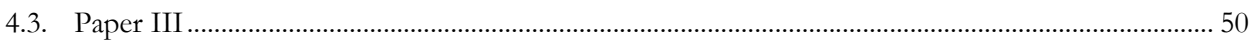

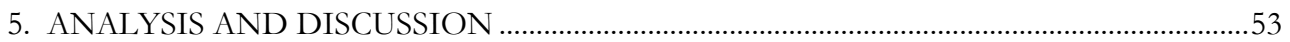

5.1. Analysis and discussion of the findings at the Haulier case ………………............................... 54

5.2. Analysis and discussion of the findings at the Forwarder case .................................................. 59

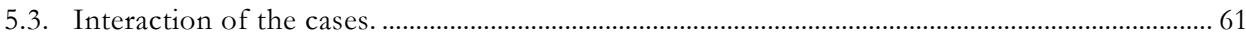

5.4. Principles of process management for freight transport companies.................................................... 64

5.5. Potential tools of process management for freight transport companies ........................................... 65

5.6. Potential benefits of process management in freight transport companies................................. 66

5.7. Potential challenges of process management in freight transport companies ........................... 67

5.8. Process management adaptations for enhancing environmental sustainability ......................... 68

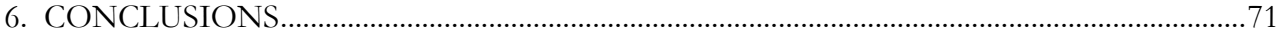

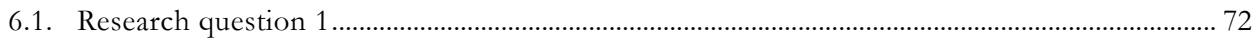

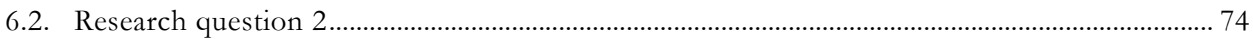

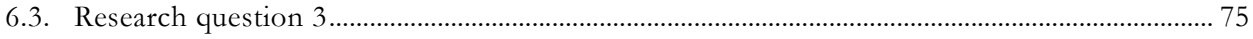

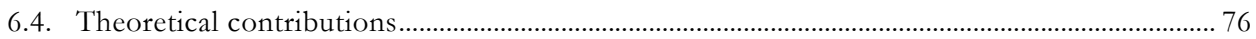

6.5. Managerial impact and implications ……....................................................................................... 76

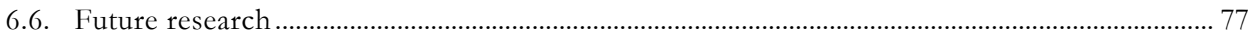

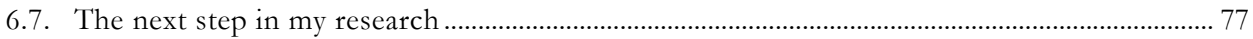

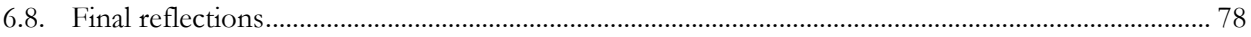

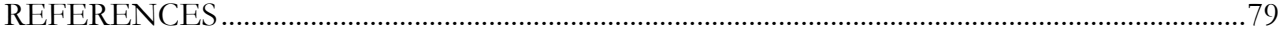

APPENDICES

INTERVIEW GUIDES

PAPER I

PAPER II

PAPER III 


\section{List of figures}

Figure 1. Greenhouse emissions for heavy and light trucks in Sweden ...........................................................

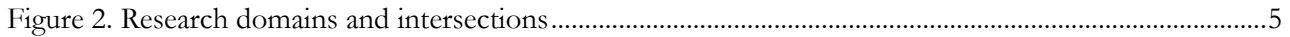

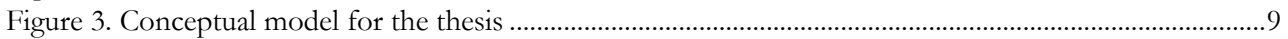

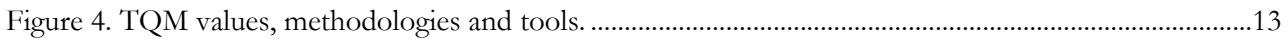

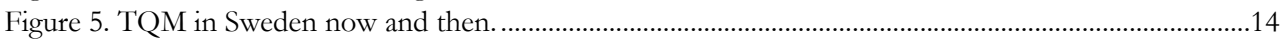

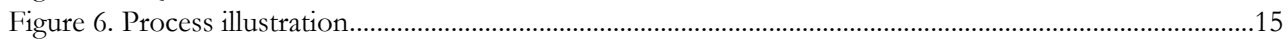

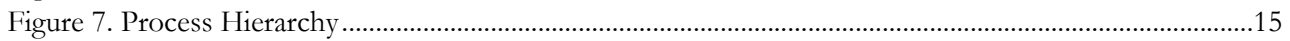

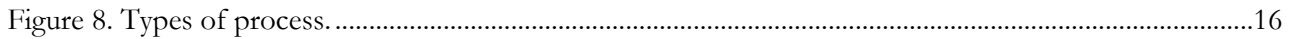

Figure 9. Process management conceptual timeline. .................................................................................22

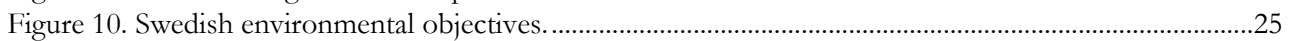

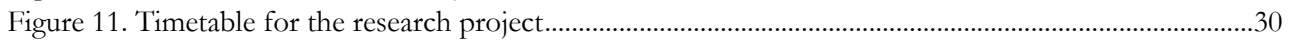

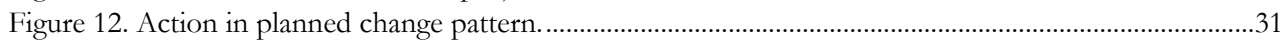

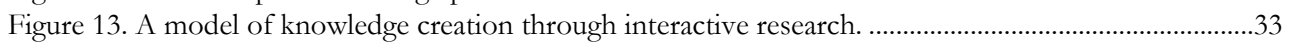

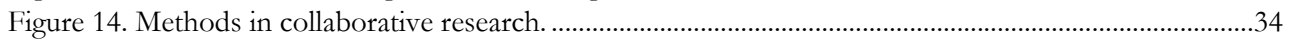

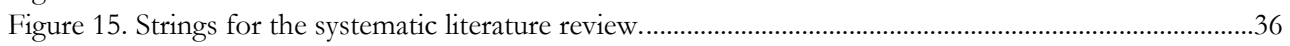

Figure 16. Results from the systematic review. .............................................................................................

Figure 17. Developed conceptual model .........................................................................................................54

\section{List of tables}

Table 1. Relation of the papers and the research questions ..........................................................................10

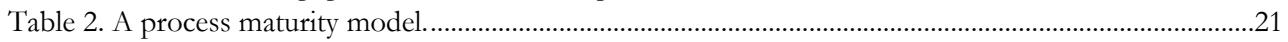

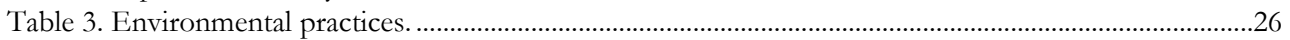

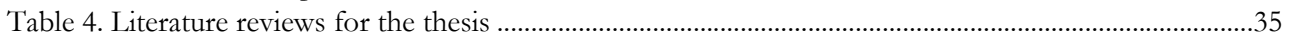

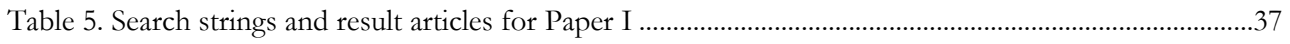

Table 6. Data collection for the Haulier case ...................................................................................................4

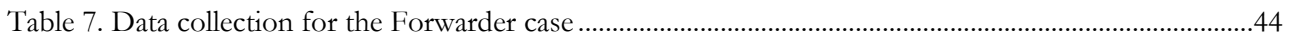

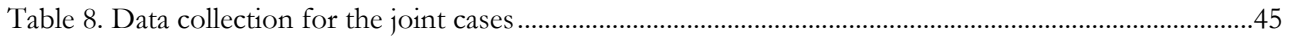

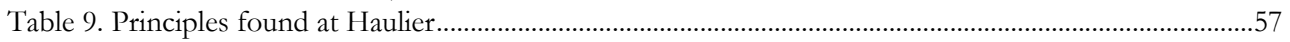

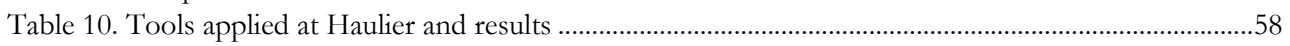

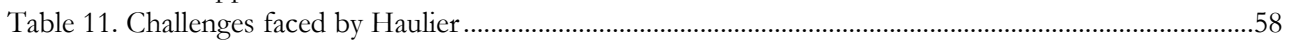

Table 12. Principles found at Forwarder ...................................................................................................62

Table 13. Tools applied at Forwarder and results .....................................................................................63

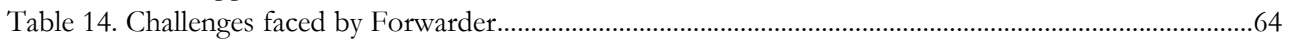

Table 15. Process maturity model associated with environmental efforts ......................................................... 70 


\section{INTRODUCTION}

In this introductory chapter, I present the background to the thesis and the theoretical context. The purpose and research questions of the thesis are presented. Furthermore, I also refer to some key concepts with the intention of providing the reader with a basic context for understanding the thesis. In this chapter, I have also included the conceptual model that shapes the thesis. 


\subsection{Background}

Sci-Fi films have presented enemies to humanity since they were first created. The list of famous adversaries against humanity is infinite, from mutants to aliens and from criminals to terrorists. They were strong roles in their time, but now there is a new bad kid on the block. Cli-Fi is a new genre of films that presents threats to the entire human race without distinction between good or bad. These movies portray climate change as an undeniable threat with a greater likelihood of occurring than finding an alien in your backyard. The reason for the success of these movies is that they present a real problem, one for which researchers have found evidence. Environmental sustainability is a concept that tries to support the minimisation of climate change. Therefore, it is of societal interest.

Quality management is not Sci-Fi, it is science and practice. As a research field, it has also made efforts to enhance environmental sustainability (e.g. Sawhney et al., 2007; Carvalho et al., 2011; Savino and Mazza, 2016; Siva et al., 2018; Green et al., 2019). Deleryd and Fundin (2015) explain that there is a trend towards quality management focusing not only on customer requirements but also on societal requirements. The Swedish Institute for Quality is a national centre responsible for the promotion of quality development in Sweden. This institute, based on research (SIQ, 2018), has explained that environmental sustainability is among the current societal requirements for organisations.

Among the many methodologies stemming from Quality Management, process management has shown itself to assist companies in achieving better results by focusing on identifying and fulfilling customer requirements, while reducing the resources needed (e.g. Cronemyr, 2007; Palmberg, 2009). Research on process management has decreased over the last decade and other tools and methodologies within quality management have become the focus of academia. In the past, process management has proven to give organisations an improved understanding of both customer needs and the organisation's strategy (Palmberg, 2009). It has helped with the standardisation of work procedures, increased the effectiveness of resources, and contributed to cost reductions and better economic control (Isaksson, 2006; Cronemyr, 2007; Palmberg, 2009; Palmberg, 2010).

It is thus interesting to investigate whether this methodology can also be helpful for identifying and fulfilling societal requirements. However, taking this comprehensive question as the purpose of a thesis would be quite ambitious due to the breadth of the question. Therefore, I intend to contribute to responding to a part of this broad challenge with this study. For this, it is necessary to focus on a more specific context and set a specific societal requirement as the target. I chose to use the target of environmental sustainability because it is a top societal requirement which is demanding more attention as time goes by. The context for conducting such an investigation is important for understanding the problem and whether the enquiry should be relevant to the context in which it will be tested. I chose the road freight transport sector for my study, and specifically small and medium-sized enterprises ${ }^{1}$ (SMEs) within the business sector. The reason for this choice is the effect that the sector has on the environment and the need for it to become more environmentally sustainable. In Sweden, the majority of road freight transport companies are SMEs. Hence, the delimitation to only this kind of companies. Below, I will further explain the selection of the context.

In 2001, the Commission of the European Communities published the White Paper: "European transport policy for 2010: time to decide" (2001) as an initiative for decreasing the negative impact of transport on the environment and to attack the problem of climate change. They determined that transport was responsible for around one quarter of the European Union's overall greenhouse gas emissions. Within that, it was estimated that road transport was responsible for more than two

\footnotetext{
${ }^{1}$ In this thesis, I use the terms companies and enterprises interchangeably. The reason for this choice is that, while doing my research, I have used the term companies but the term small and medium-sized enterprises (SME) is an established concept that is used in both practice and academia.
} 
thirds. Therefore, it was decided in 2015 that enhancing environmental sustainability was a primary goal for the transport sector within the European Union (Márquez-Ramos, 2015). Consequently, two goals were set: 1) to decrease greenhouse gas emissions by $20 \%$ of 2008 levels by 2030 , and 2) to reduce these emissions by $60 \%$ of 1990 levels by 2050 . The first target was later confirmed by the "Policy framework for climate and energy in the period from 2020 to 2030 " published by the European Commission (2014).

Since the White Paper was published, several governments have started to identify ways to reach that goal, the Swedish government being one of them. They have analysed the problem from several perspectives and conducted research in several fields on ways to reach the goal. Furthermore, the Swedish parliament has decided that the country should become climate neutral by the year 2045. This will not be an easy goal to achieve for the transport sector (Fossil Free Sweden, 2018). To illustrate this, Figure 1 presents a chart showing the amount of greenhouse emissions attributable to road freight transport in Sweden. On the chart, it is possible to observe an increasing trend in greenhouse emissions from 1990 to 2008. After 2008, there is a slight decreasing trend in these emissions. However, the slope of the trend between 2008 and 2017 is not promising for achieving the European goals for 2030 and 2050 (European Commission, 2014), nor is it promising for achieving Sweden's goals for 2045 (Fossil Free Sweden, 2018). The slope suggests a slow reduction in greenhouse emissions. Carbon emissions were reduced by only $31 \%$ from 2010 to 2017 for heavy traffic in Sweden and it has been estimated that, if these conditions remain as they are, the carbon emissions will only decrease by $28 \%$ between 2010 and 2030 (Trafikanalys, 2019b). This estimated decrease is well below the established goal of $70 \%$ for 2030 .

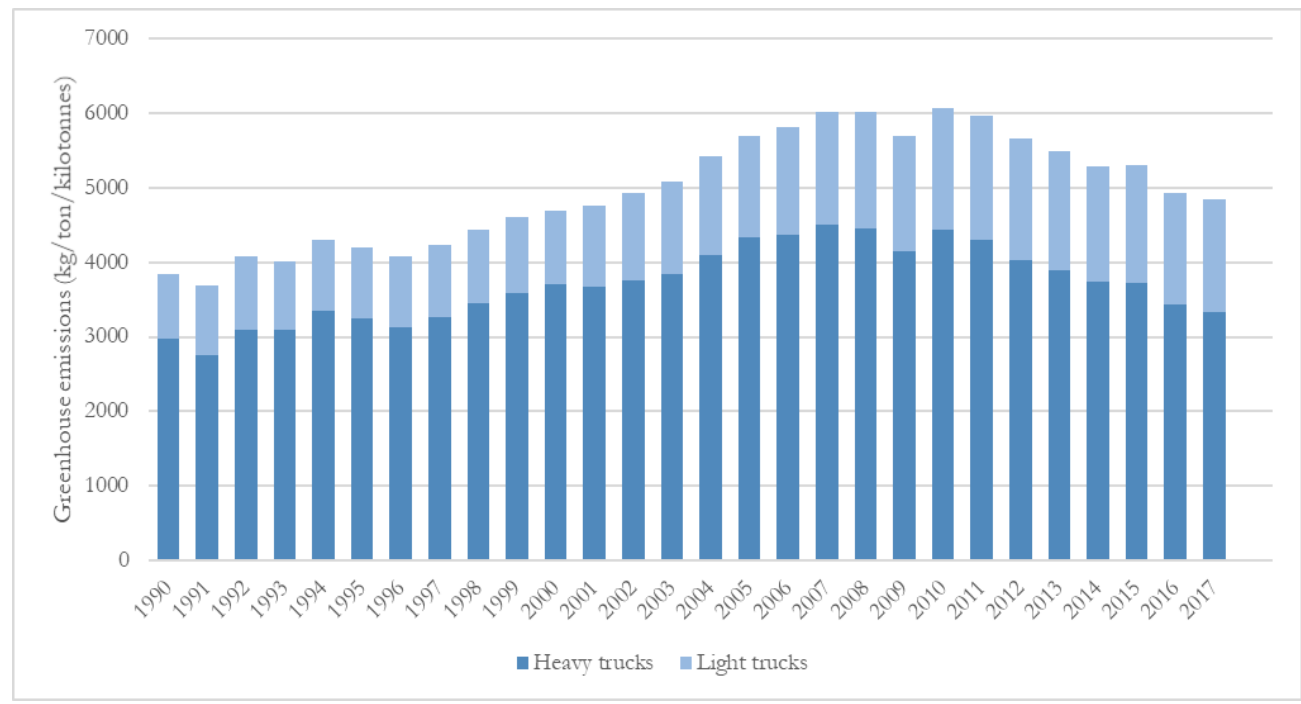

Figure 1. Greenhouse emissions for heavy and light trucks in Sweden Source: SCB, 2018.

With its goal for 2045, the Swedish government published a series of policies and reforms. The number of trucks belonging to the road freight transport sector is expected to increase by $39 \%$ between 2018 and 2040 (Fossil Free Sweden, 2018). It is thus imperative for the transport sector to find effective solutions to decrease their environmental effect. However, from a practical perspective for the freight transport sector, there are no clear or concrete solutions offered by the government for decreasing their environmental effect. This presupposes a big challenge for the companies in this business sector. They now face not only the major task of decreasing their emissions by a significant percentage but also the need to meet the high demands from their customers for high-quality services at reasonable cost (Evangelista et al., 2017). The road freight 
transport sector is also making efforts to achieve the goal (e.g. Evangelista and Sweeney, 2014; Andersson et al., 2019). However, the efforts have not been enough, as evidenced by the chart in Figure 1. Hence, tools are needed to achieve this reduction (Evangelista et al., 2013). Furthermore, research on the road freight transport sector has been mainly performed within large companies (Lieb and Lieb, 2010) while most of the companies from this business sector in Sweden are small to medium-sized (Sveriges Åkeriföretag, 2019).

The competitive pressures within the freight transport business sector are considered to be high, with customers expecting high levels of service, short delivery times and low costs (Evangelista and Sweeney, 2014; Andersson et al., 2019). This need to optimise their resources certainly translates into a need to be more innovative and creative in order to improve their efficiency (Andersson et al., 2019). The need for innovation and optimisation, together with the environmental goal call for new efforts in different areas, including managerial approaches (Evangelista et al., 2017). I consider that this business sector has certainly begun with setting goals for optimizing resources and having more environmentally sustainable businesses; but it needs to determine the best achieve to reach that end. Environmental sustainability is not a tangible goal per se. However, the goal for the freight transport business sector is to continually improve its environmental sustainability.

To illustrate the magnitude of the problem for freight transport companies, we can look at the so-called last mile issue. Today, it is quite common for customers to choose to buy their goods through e-commerce, instead of going to stores. This situation presupposes, in many cases, that the goods will be delivered to the customer's door by a transporter. Also, the return of goods can be achieved by sending the goods directly back to the company instead of going to a physical store. Consequently, the number of transports needed by transport companies has increased. This situation has led not only to new management and operational challenges, but also to a larger environmental footprint in this business sector. Additionally, the emergence of new technologies, along with advances in the business sector, such as new vehicles and fuel, presupposes a need for rapid adaptability and flexibility in companies' managerial strategies to be able to embrace these changes and survive the evolution of the business sector. Therefore, there is a current need to find solutions in all aspects of the organisations within the road freight transport sector to make them more efficient and environmentally sustainable.

In the companies within the freight transport sector, quality management and transport management are disciplines that are considered to go hand in hand. Quality is usually embedded in the transport services; customers need the right goods to be transported to a specific destination at the right time, and the companies need to manage their services in such a way that they can guarantee the fulfilment of these requirements. Therefore, when these organisations consider quality management, they see it as an aspect that is not separate from their transport services. On the other hand, in research, they are considered and studied as separate disciplines. Hence, I consider it interesting to research ways in which these two disciplines can relate.

In this thesis, I focus on the use of process management in the road freight transport sector. From a quality management perspective, we found that research has not commonly targeted this business sector (Navarro et al., 2018a). My intention with this thesis is to investigate whether process management could be a potential tool for the road transport sector to enhance environmental sustainability while satisfying customers' requirements. I present an investigation on how the specific advantages of process management, which are not always present in other quality management approaches, could support freight transport companies in going green. This study could also be a re-visit to process management and contribute to identifying new opportunities for the methodology within research. For identifying these new opportunities for process management in research, I aim to expand the field within which it is used and demonstrate the potential for its use in the road freight business sector, specifically for achieving environmental sustainability. At the same time, I aim to contribute to the companies in that business sector with an applicable methodology that helps them not only to achieve their environmental goals but also to manage 
their operations more efficiently. From an academic point of view, I intend to contribute to three different disciplines. The academic position of my research is explained in the following section.

\subsection{Positioning the research}

This thesis targets the intersection between three domains that are commonly separate academic disciplines: process management, freight transports and environmental sustainability. The objective of this thesis is to investigate how process management can be used as a tool within the road freight transport business sector context in order to fulfil the demands and opportunities that come with the objective of environmental sustainability. To present this purpose in a simple way and illustrate the areas included in the frame of reference, Figure 2 was developed. The star at the centre of the figure represents the area of interest for my thesis. However, the areas of intersection are also included as part of the investigation. The intersection between environmental sustainability and freight transport can be included in green logistics. Green logistics is an established research field that aims to assess and reduce the environmental impact of logistics (McKinnon, 2015). This thesis is intended to contribute to filling a gap that exists mainly in the intersection of the three domains, the star in the figure, with a process management focus.

I use this model to illustrate the positioning of my study and retain a connection between these three domains throughout the thesis. The three domains included in the model constitute the frame of reference for this thesis. However, I present each one briefly below.

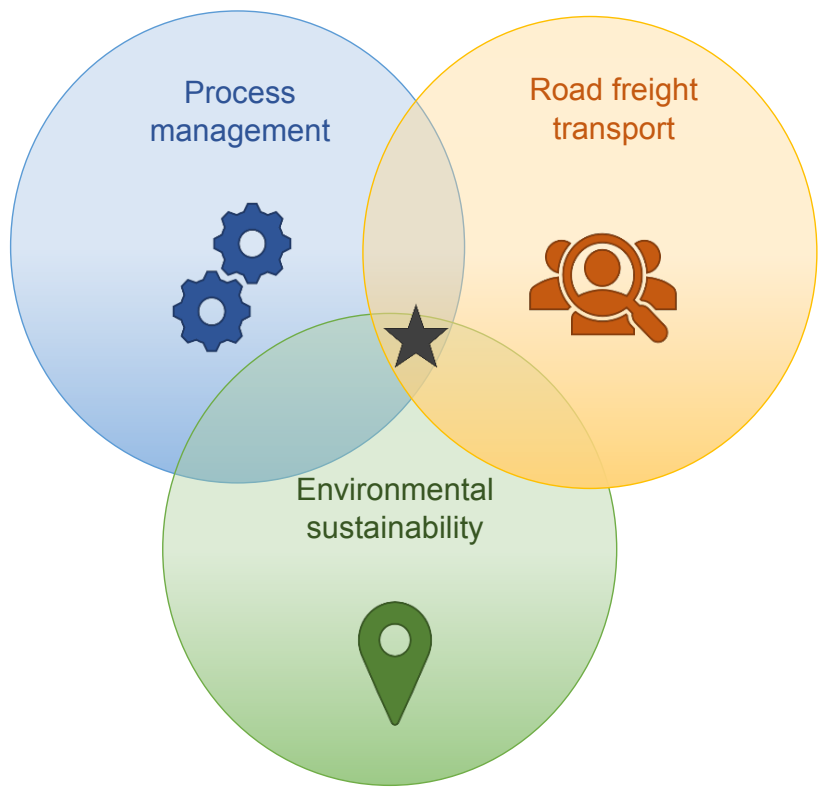

Figure 2. Research domains and intersections

\subsection{The process management methodology}

As customers, we tend to choose products and services of high quality. In services, for example, we look for characteristics such as credibility; we want to be able to trust in our service provider. This striving towards high quality has created a need within business to develop ways of improving and innovating. This is how Quality Management was born. 
Quality management began with the creation of inspections, standards and statistical processcontrol techniques. Later, a perspective across the entire organisation was involved and received the name of Total Quality Management. Years later, a focus on processes was included with the purpose of achieving customer satisfaction (Deming, 1986; 1994). This led to the creation of process management, which is a methodology within Total Quality Management with the customer as focus (e.g. Paim et al., 2008; Palmberg, 2009). This thesis is based on process management methodology.

Process management methodology strives towards identifying the needs of both internal and external customers and satisfying those needs (Cronemyr, 2007). In practice, there is a common misconception when referring to process management. Various practitioners consider that all the activities in their organisations are processes and that process management is about managing those activities. However, process management methodology is much more than that. It involves establishing processes, which are activities that take customer needs and add value to them so that they can satisfy the customer. After the processes are established, it is necessary to manage, control and continuously improve these processes (e.g. Paim et al., 2008; Cronemyr and Danielsson, 2013).

Process management has proved to be a viable methodology for fulfilling customer requirements in other business sectors. It has also proved able to provide structure, fact-based decision-making and a clear understanding of the organisations, among other benefits (e.g. Ahire and Dreyfus, 2000; Palmberg, 2009; Palmberg, 2010; Da Silva et al., 2012). This methodology is further explained in the frame of reference.

\subsection{The freight transport business sector}

This sector is part of the discipline of logistics and involves the movement of goods between places by means of road, air, rail and maritime transportation (Kohn and Huge-Brodin, 2008). Customers of this business sector are mostly interested in getting the right goods to the right destination in the right condition and at the right time. These requirements pose many challenges; therefore, many researchers have made this business sector the focus of their studies.

In Sweden, more than $60 \%$ of the total freight transport is achieved by means of road transport (Trafikanalys, 2016). The Swedish parliament has decided that, by 2030, the road freight transport sector should reduce the greenhouse emissions from heavy trucks by at least $70 \%$ compared to 2010 levels. Furthermore, a goal has been set for this business sector to become completely fossil free by 2045 (Fossil Free Sweden, 2018). The Fossil Free Sweden project states that the main driving forces behind road freight companies' efforts to reduce their emissions include customer demand, cost reduction and an ambition to contribute to fighting global warming (Fossil Free Sweden, 2018). However, they also mention that a challenge for these companies is that the goals have been stated by the government but there is a lack of willingness from their customers to invest in services with lower environmental impact.

The road freight transport sector has been characterised by several researchers as a low-margin business sector with extreme competitive pressures (e.g. Oskarsson et al., 2003; Evangelista and Sweeney, 2014). Profits in the freight transport sector are relatively low compared to other logistics activities. Customers of this business sector demand high levels of service and low costs, which creates a need for the companies to optimise performance and be more innovative in developing solutions. These extremely competitive conditions for the companies within the sector make innovation a requirement. This business sector is also considered to be exposed to fast-moving technological developments in vehicles, combustibles and requirements (Evangelista and Sweeney, 2014).

It has been estimated that the road freight transport sector is accountable for approximately one third of the total emissions from the freight transport sector. Therefore, many researchers have studied ways to improve the environmental sustainability of these operations. Within academia, most of the publications that target environmental sustainability in this business sector refer to the 
green logistics discipline. Among green logistics, there has been research on the design of logistics systems, the magnitude of emissions and their carbon content, corporate strategies that support environmental practices and collaborations among different parts of the supply chain to enable a reduction in the environmental effects (e.g. Aronsson and Brodin, 2006; Colicchia et al., 2013; Piecyk, 2015; Sallnäs, 2016). However, there is still a lack of tools and knowledge that support the greening of the freight transport sector (Evangelista et al.; 2013). The Swedish Association for Road Transport Companies (Sveriges Åkeriföretag, 2019) reports an approximate of 6000 hauliers which are members of the association. Sveriges Âkeriföretag (2016) mentions that the majority of the business sector in Sweden involves SMEs. Therefore, this thesis is focused on SMEs of the road freight transport business sector. Consequently, my research is a contribution to that knowledge for the road freight transport business sector.

This business sector constitutes the context of the thesis and is further explained in the frame of reference.

\subsection{Environmental sustainability}

The concept of sustainability is not new, it has been around since the 1980s. It refers to not overutilising existing resources from an economic, social or environmental point of view. The purpose of sustainability is to utilise resources in such a way that they are preserved for future generations (Brundtland, 1987). Goodland (1995) considers environmental sustainability, from an industry point of view, to be a concept that refers to encouraging technological development and operational activities in such a way that they enable renewable resources to be able to regenerate, and to find renewables that can replace non-renewable resources. Goodland (1995) also mentions the need for technological progress to be efficiency-increasing rather than throughput-increasing, meaning that organisations should strive to use technology to optimise resources instead of increasing the magnitude of the outcomes. Foy (1990) explains the concept of environmental sustainability from an economic point of view. He considers that current economic activity should not disproportionately affect future generations.

Environmental sustainability is not a concept that can be turned into a goal (Ammemberg, 2018). This is because it should be considered as a development and a concept that is continuously improving. Therefore, I consider the goal to be for a business sector to become more environmentally sustainable. The business sector, in this particular thesis the road freight business sector, should utilise environmental resources wisely so that they are preserved for future generations, and should strive towards continuously improving their environmental sustainability. However, for practical reasons, in this thesis, I will refer to environmental sustainability as the objective. To do so, organisations need to ensure that their operations allow them to achieve their desired profit margins while still preserving resources for future generations. This requires efforts from technological, operational, managerial and strategic points of view.

Enhancing environmental sustainability represents the objective for the freight transport business sector and is explained further in the frame of reference. From the star in the model (Figure 2), the purpose of the research project on which this thesis is based and my own experiences and knowledge, I narrowed down the aspects included in the area and designed the purpose of the thesis and the research questions. These are presented below.

\subsection{Purpose and research questions}

Process management has been used by several business sectors, where it has proved to be a good approach to fulfilling customer demands. Additionally, in some sectors, this methodology has contributed to an increase in the environmental sustainability of businesses. However, the use of process management in the context of the road freight transport business sector is presumed to be rare. With this thesis, I intend to contribute to the field of quality 
management, and specifically to process management methodology. I investigate the use of this methodology in the road freight transport sector, particularly for enhancing environmental sustainability. This research could also contribute to the presenting new opportunities for the process management methodology in both academia and for practitioners. Hence, I present the purpose of this thesis as follows:

\section{To explore the possibilities of using process management to support the greening small and medium-sized companies of the road freight transport sector}

In the journey towards achieving this purpose, I have identified three main points of interest. Each of these is targeted by a research question.

Before applying a methodology such as process management, it is important to understand its values. Hence, I start by identifying the principles of process management that most effectively adapt for the freight transport sector to enhance environmental sustainability. Furthermore, process management methodology involves several tools, such as process mapping and statistical process control (Palmberg, 2009). However, it is important to determine which of the tools included in the methodology are potentially useful to the freight transport sector to increase its environmental sustainability.

\section{RQ1: Which principles and tools from process management are potentially useful for freight transport companies to enhance their environmental sustainability?}

After determining both the principles and tools, I consider it relevant to explore the path towards environmental sustainability when taking the process management direction. Therefore, I intend to identify the possible benefits and challenges that the freight transport sector might encounter in its journey towards becoming more environmentally sustainable by using process management. These benefits and challenges are targeted in RQ2.

RQ2: What benefits and challenges might road freight transport companies face when using process management to enhance their environmental sustainability?

Finally, RQ3 digs more deeply into process management methodology. As mentioned above, it is presumed that the use of process management has been rare in freight transport companies. Consequently, it is also presumed that the introduction of this methodology to the companies within this sector has also rarely been studied. This represents a need to introduce process management methodology to those companies and to determine what changes are needed within this methodology to adapt it to the needs in freight transport companies for enhancing their environmental sustainability.

RQ3: How could process management be adapted to enhance environmental sustainability in road freight transport companies?

RQ1 and RQ2 are intended to make a greater contribution to Logistics research by providing a methodology that supports the greening of the freight transport business sector. These two research questions contribute to Quality Management with a study of the implementation of process management in the context of the road freight transport sector. Furthermore, RQ3, which is based on RQ1 and RQ2, is intended to make a greater contribution to Quality Management research by suggesting what adaptations to process management are required for the methodology to support the enhancement of environmental sustainability. 
For answering the research questions and reaching the purpose of this thesis, I designed the abstract conceptual model presented in Figure 3.

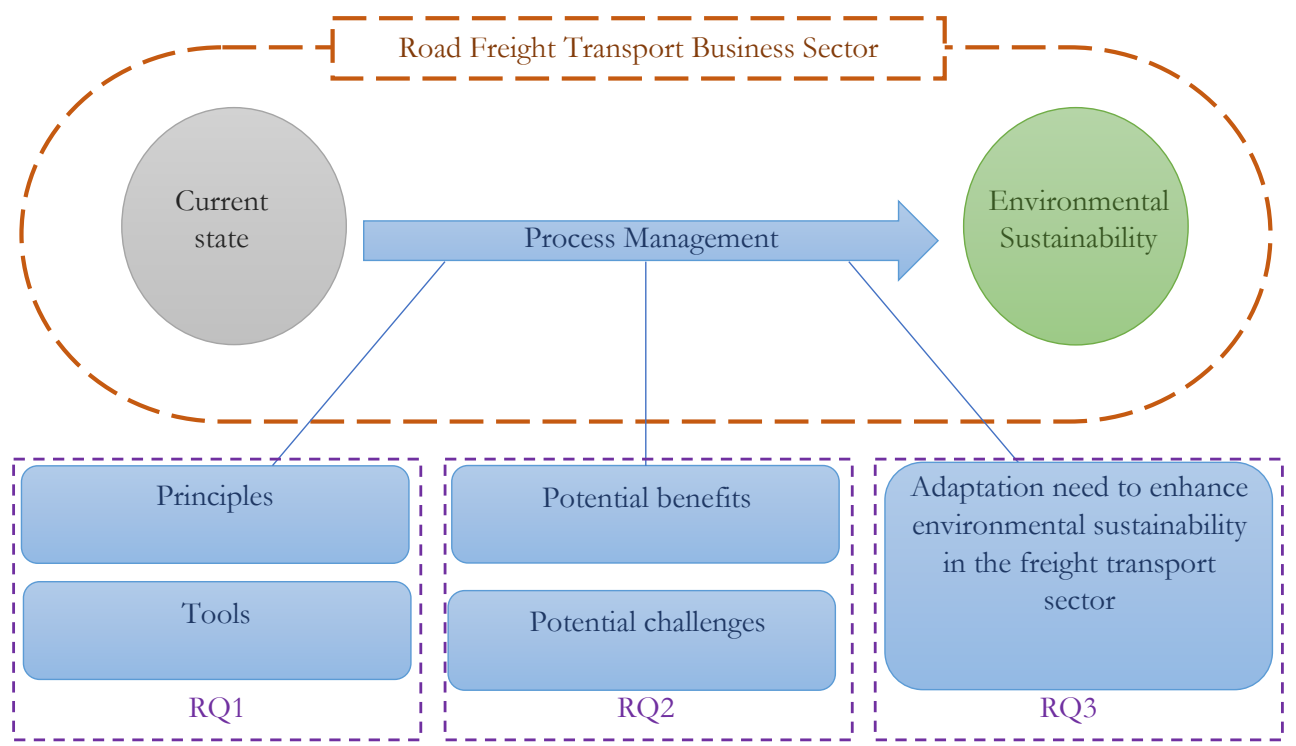

Figure 3. Conceptual model for the thesis

In the conceptual model illustrated in Figure 3 it can be observed that the purpose of the thesis is to change the current state of companies, illustrated by the circles, to a state displaying enhanced environmental sustainability. This is achieved by using process management, represented by the arrow in the figure. This is delimited to SMEs within the road freight transport business sector, which is illustrated by the dashed line. Finally, for process management to be applied to these companies, I have designed the three research questions, which are represented by the rectangles supporting the arrow.

\subsection{Delimitation and scope}

For the purpose of this thesis, I use the context of road freight transports as the business sector in focus. The research is intended to focus on the process management methodology within the disciplines of quality management. Additionally, I am aware that sustainability is a concept that involves three aspects, the environmental, the social and the economical (Brundtland, 1987). Due to its principles and values, process management tends to influence the enhancement of economic sustainability, in terms of the effectiveness of economic resources (Palmberg, 2010). However, this thesis is limited to the study of environmental sustainability. I refer to green logistics throughout the thesis. This concept studies a broad variety of issues, from the recycling of materials to the development of new vehicle engines for reducing the environmental effect of logistics (McKinnon et al., 2015). My study focuses on the managerial aspects of green logistics for freight transport companies and their strategies to reduce their environmental impact. The companies involved in my thesis are SMEs. This fact implies that some of the results of this thesis would require a revisiting when applying them to large companies. 


\subsection{Outline of the thesis}

The second chapter includes the frame of reference used for the analysis of the results of the study. The method for the development of the study is described in Chapter 3. Three papers will be included in the thesis; they are briefly described in Chapter 4. Table 1 shows the connection between the research questions and the three papers. Chapter 5 presents the analysis and discussion of the results of my study. Finally, I present the conclusions of the thesis in Chapter 6.

Table 1. Relation of the papers and the research questions

\begin{tabular}{|c|c|c|c|}
\hline Paper & RQ1 & RQ2 & RQ3 \\
\hline Paper I & $\mathrm{x}$ & & \\
\hline Paper II & $\mathrm{x}$ & $\mathrm{x}$ & $\mathrm{x}$ \\
\hline Paper III & & $\mathrm{x}$ & $\mathrm{x}$ \\
\hline
\end{tabular}




\section{FRAME OF REFERENCE}

This chapter presents the theoretical basis for the thesis. I present the literature I have used from each of the three domains presented in Figure 2: process management, freight transport and environmental sustainability. Additionally, I have included a section for each of the intersections between the three domains. 


\subsection{Total Quality Management}

The concept of Total Quality Management (TQM) emerged after the Second World War when there was a need for high-quality products while the world was struggling to deal with the limited resources that were available (Soltani et al.; 2008; Dahlgaard-Park, 2011). However, the term TQM emerged during the 1980s and, to date, the concept has changed and adapted to the needs of organisations (Soltani et al.; 2008).

Several definitions of TQM have been presented over the years (e.g. Oakland, 1993; Dahlgaard et al.,1997; Dahlgaard-Park and Zink, 2007; Soltani et al., 2008). TQM is a concept that has proved difficult to define (Klefsjö et al., 2006). Nonetheless, researchers agree that it is a management approach that focuses on quality, involves all parts of an organisation and strives to achieve customer satisfaction. Hellsten and Klefsjo (2000) explain that TQM is a management system that is continuously evolving and consists of three components: values, techniques and tools. They argue that the purpose of using TQM is to increase the satisfaction of both internal and external customers while reducing the amount of resources needed. The authors consider these values to be the cornerstones of TQM and explain that these cornerstones need to be supported by the appropriate methodologies and tools. Figure 4 illustrates an adaptation of Hellsten and Klefsjo's (2000) argument. Each of the cornerstones is explained below.

Hellsten and Klefsjö (2000) consider that customer satisfaction can be achieved when an organisation is able to identify its customers' needs and wishes while systematically aiming to fulfil those needs and expectations via the product or service offered. Customer satisfaction must be achieved for both internal and external customers (Hellsten and Klefsjö, 2000; Bou-Llusar et al. 2009).

Basing decisions on facts is another value of TQM. This refers to the strategy of making decisions based on facts, such as the current performance of the company, and their relation to the goals set by management.

A focus on processes, and specifically a process view, is another important value for TQM. This implies looking at processes instead of organisational units' results and having a broader picture of how the company is doing.

Continuous improvement ensures that the company provides better solutions to its customers and allows it to retain its competitiveness in the market. This is the reason why improvement is considered to be one of TQM's values. These improvements involve, for example, obtaining higher quality of the products and/or services and the effectivisation of resources.

To achieve improvements in a company, it is important to ensure that all the involved parts are committed and participate actively towards achieving the company's goals. This includes primarily employees but also suppliers, and constitutes the final value proposed by Hellsten and Klefsjö (2000).

Several researchers agree that, in order to comply with the values listed above, management commitment is indispensable (Crosby, 1979; Oakland, 1998; Cronemyr, 2007; Soltani et al., 2008). Having a leadership at all levels of the organisation that is engaged in creating a culture that strives for quality improvements is an essential value for TQM.

These six values require the support of certain methodologies. Several examples of the methodologies and tools supporting TQM are presented in Figure 4. In this figure, one of the examples of the methodologies involved in TQM is process management. This methodology has proved to be beneficial for achieving the values of TQM, especially for its focus on process and on customer satisfaction. The methodology is further explained below. 


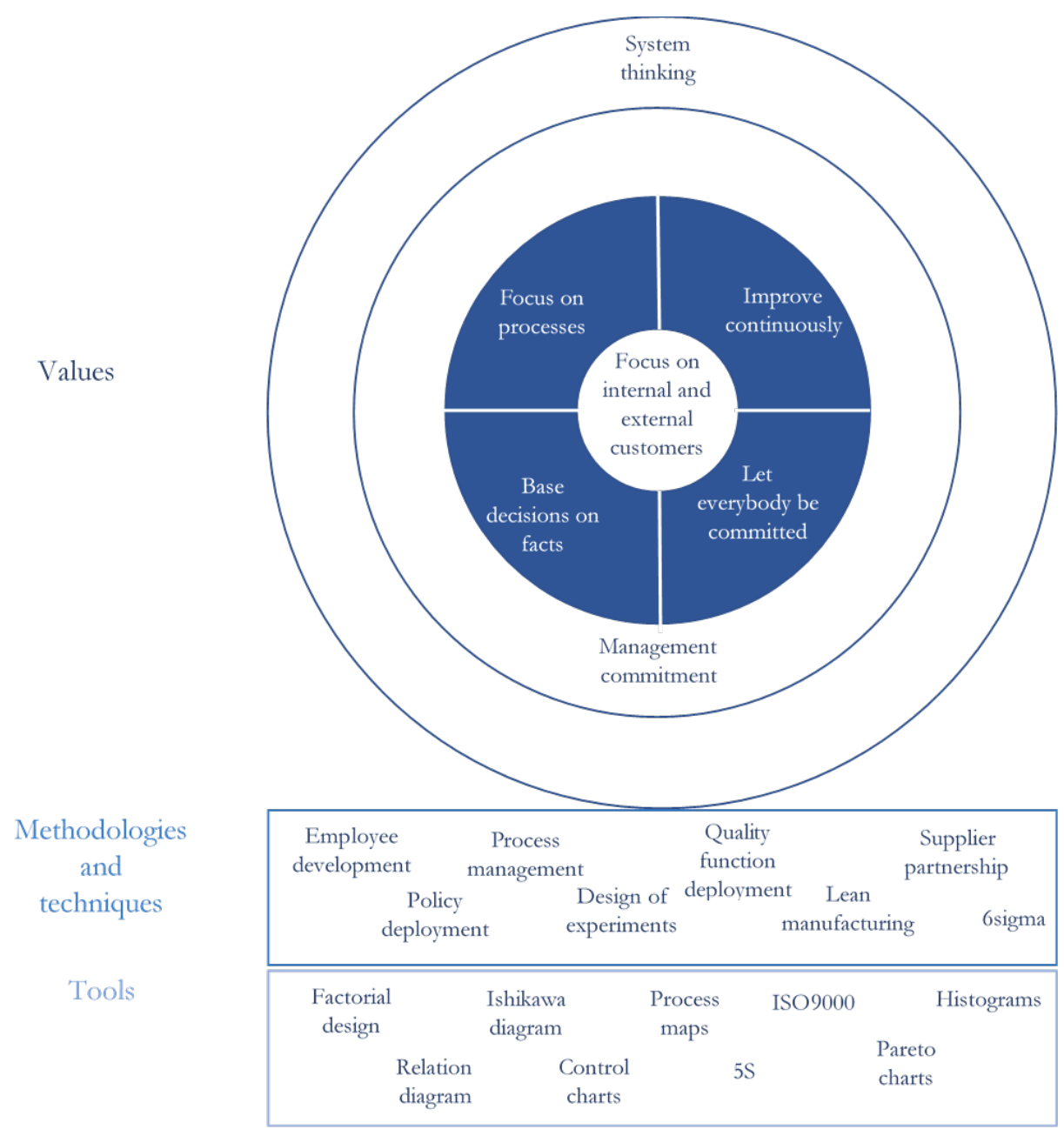

Figure 4. TQM values, methodologies and tools.

Adapted from Hellsten and Klefsjö (2000).

Kroslid (1999) developed a dual-path framework, shown in Figure 5, in which he categorised certain practices of quality management depending on the level of development, the focus of the practices and the theoretical school to which they belonged. Furthermore, Kroslid (1999) determined that at that time, Sweden belonged to a category in which practices are focused on the culture and there is a striving for continuous improvements in processes, products and services. Kroslid (1999) also explained that the focus on the culture is based on a focus on processes. More recently, Deleryd and Fundin (2015), determined that until today, TQM has focused on achieving customer satisfaction. They identify a new trend within quality management whereby organisations continue to aim to satisfy their customers, but also aim to achieve a higher level of societal satisfaction. This is illustrated in Figure 5. 


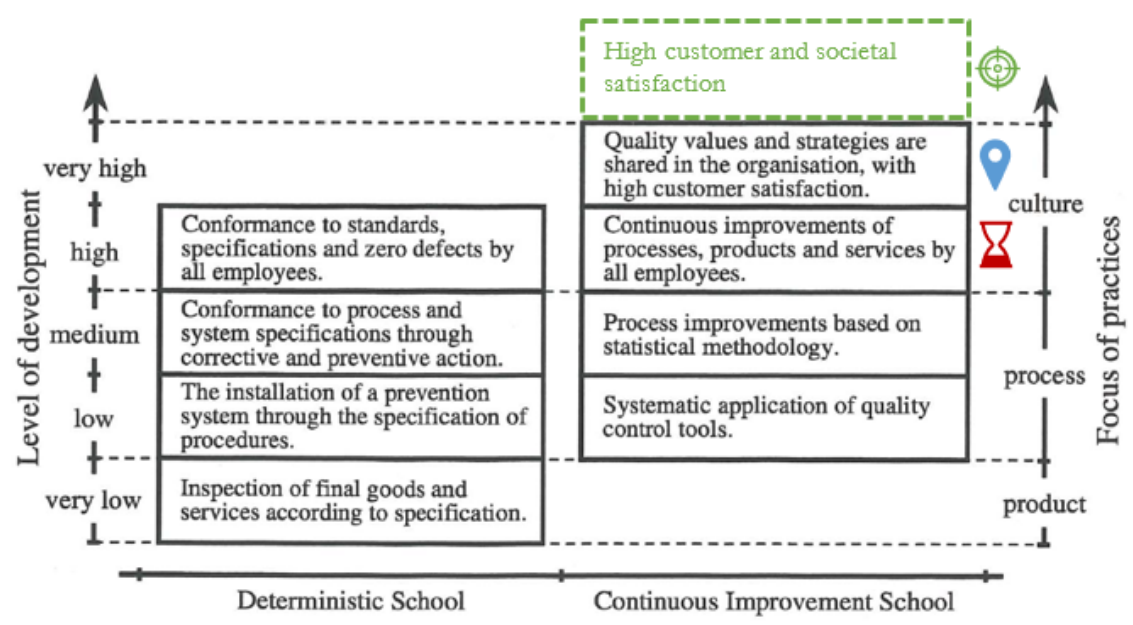

Z Quality Management in Sweden, 1999
Quality Management in Sweden 2019
(9) The future of Quality Management in Sweden

Figure 5. TQM in Sweden now and then.

Based on Kroslid (1999) and Deleryd and Fundin (2015).

The Swedish Institute for Quality (SIQ, 2018) explains that sustainability is among the requirements that society imposes on today's organisations, including environmental sustainability. They consider that organisations can obtain better results in all three aspects of sustainability (social, economic and environmental) when they focus on a number of specific elements, such as improving their processes. Process Management is a methodology that strives for continuous improvement. Therefore, it is the focus of this thesis and is explained in the following section.

\subsection{Process Management}

\subsubsection{Process}

Before presenting process management, it is necessary to define the concept of process. This concept has not been easy to define and there is still no universally accepted definition for it. However, various scholars of quality management and operations management have attempted to develop a definition. In 1991, Harrington defined process as any activity or group of activities that adds value to an input and provides an output to a customer, who can be internal or external. Davenport (1993) refers to process as a set of measured activities and structures that produce a specific output for a given customer or market. Hammer and Champy (1993) consider that a process is a collection of partially ordered activities that utilise one or several inputs to create an output with value for the customer. In this thesis, I will consider the following definition of process, inspired by the definitions presented above.

\section{A process is a group of interconnected activities that transform input into a valuable output for a customer, who can be either internal or external.}

In a process, the input involves the customer's requirements, their needs. The term customer includes owners, stakeholders and external customers, but also internal customers, such as other processes in the organisation. Based on SIQ (2018) and Deleryd and Fundin (2015), the term 
customer could also include society. Therefore, the input may vary between owners and internal and external customer needs. Similarly, the output should be the fulfilled needs of those customers.

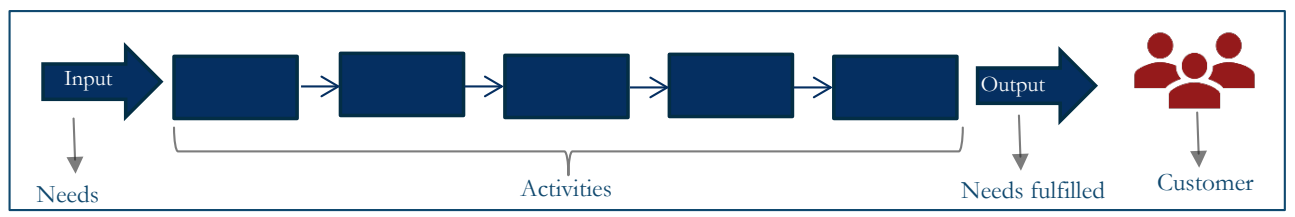

Figure 6. Process illustration

This process definition is illustrated in Figure 6.

When referring to processes, it is possible to identify a hierarchy: process, sub-process and activities (e.g. Harrington, 1991; Palmberg, 2009). This is shown in Figure 7.

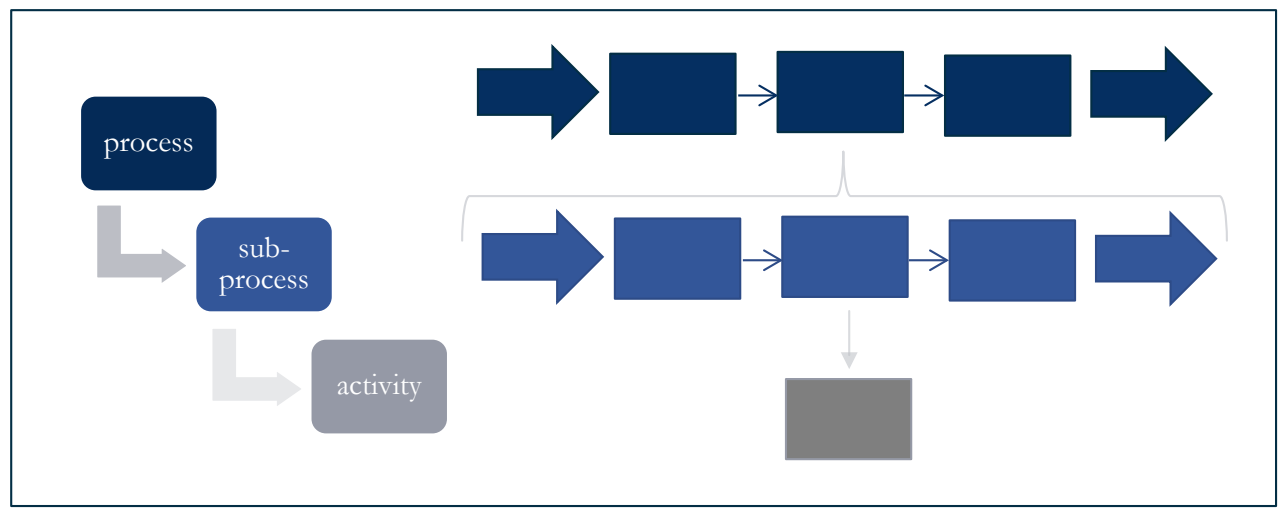

Figure 7. Process Hierarchy

At a higher level of distinction, the so-called main processes can be catalogued into three types: management processes, core or business processes and support processes (DeToro and McCabe, 1997; Nilsson, 1999; Cronemyr and Danielsson, 2013). They are explained below and illustrated in Figure 8.

a. Management processes: this kind of process deals with strategies and the setting of goals for the company. In these processes, relevant managerial decisions are taken, such as which improvements to implement within the company, strategic planning, budgeting and auditing. These are the processes that control the organisation and steer it so that the core processes can achieve their purpose. The owner or management team is usually considered to be the customer for this kind of process.

b. Core or business processes: these processes usually start with an expressed need from an external customer. Consequently, they result in outputs that have value for that external customer. These processes are extremely relevant to an organisation since it is through them that the organisation generates income.

c. Support processes: as their name suggests, these are the processes that provide resources and inputs for the management and core processes, especially the core processes. This type of process fulfils internal needs and is therefore related to internal customers. 


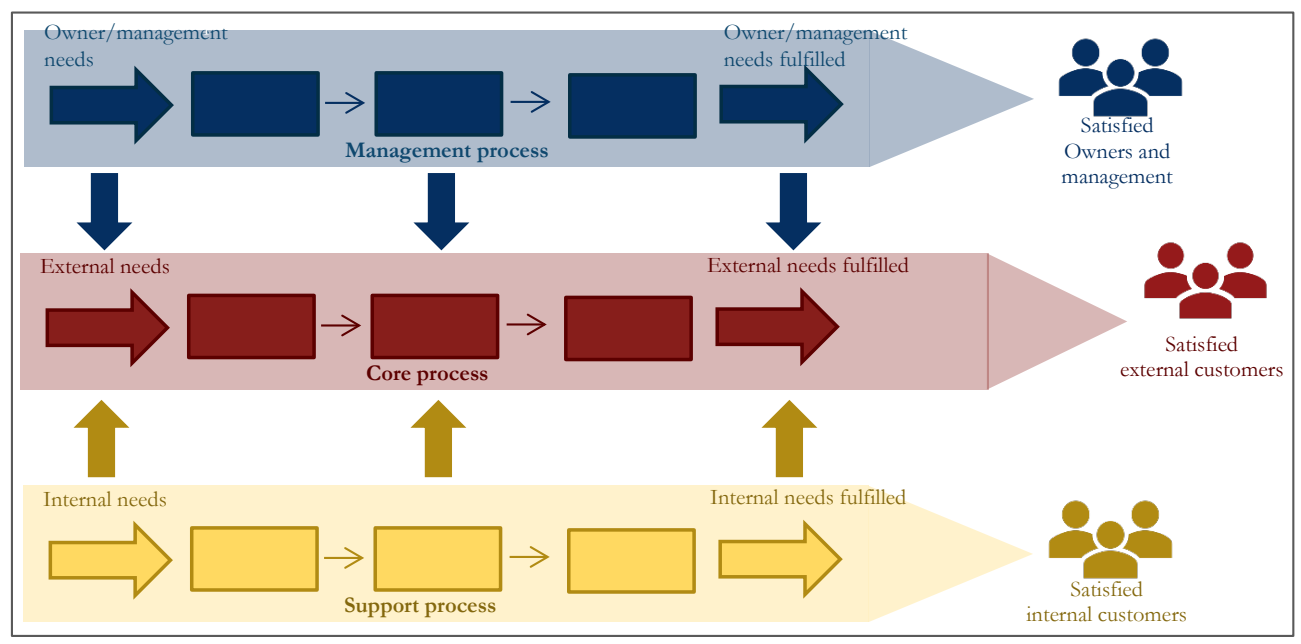

Figure 8. Types of process.

Based on Nilsson, L. (1999) and Cronemyr and Danielsson (2013).

Cronemyr and Danielsson (2013) state that these processes are focused on fulfilling the needs of customers rather than the functions of the departments within the company. Paim et al. (2008) explain that, in an organisation with functional management, the management is departmentalised and usually unintegrated. In contrast, they explain that, under a process-oriented management approach, the value can be aggregated horizontally by focusing on processes from the supplier to the customer instead of the departments within the organisation. This enables organisations to develop a stronger integration and a better understanding of the organisation and customers' expectations (Paim et al. 2008). Process management is a managerial approach that embraces this process-oriented administration and enables organisations to have their basis in the different processes needed to fulfil their customers' requirements, instead of focusing on their functional structures. Chang (2006) explains that, within functional organisation, the work unit is the department and the key figure is the functional executive, while in process organisation the work unit is the process team and the key figure is the process owner. The process management methodology is based on a process organisation supported by the functional structure. This methodology is further explained below.

\subsubsection{Process management methodology}

Bawden and Zuber-Skerritt (2002) mention that process management emerged out of a shift in focus from products to the processes required to produce them. Palmberg (2009) presents two perspectives for looking at process management based on the existing literature. The first perceives it as a structured and systematic approach for analysing and continually improving processes. The second sees it as a holistic form of management for all aspects of business and a valuable perspective in determining the effectiveness of an organisation. Other authors refer to process management as a way to organise quality work for increasing customer satisfaction and reducing internal costs (Cronemyr and Danielsson, 2013). This methodology has been defined by several other researchers (e.g. Benner and Tushman, 2003; Paim et al., 2008; Hellström and Eriksson, 2013). However, there is still no agreement on a common definition for this methodology. From the previously cited definitions and considerations of process management, I define this methodology for my thesis as follows: 


\section{Process Management is a structured managerial approach to continually operating and improving processes with the purpose of obtaining higher quality, gaining more satisfied customers and reducing non-conformance costs}

According to several researchers (e.g. Paim et al., 2008; Palmberg, 2009), process management is a methodology that plays an important role in an organisation's internal communication, specifically along stages that run through activities and processes. Another benefit of process management that researchers have found is that it increases the structure and systematisation within companies while allowing a focus on fulfilling customers' requirements (Paim et al., 2008; Palmberg, 2009).

\section{Principles of process management}

Researchers on process management methodology have identified certain principles that form the basis of the methodology (e.g. Cronemyr, 2007; Palmberg, 2009; Bergman and Klefsjö, 2010; Hellström and Eriksson, 2008; Kohlbacher and Gruenwald, 2011). Customer focus is one of the principles I consider in this thesis (Bergman and Klefsjö, 2010). As a start for process management, it is important to identify the customer's requirements, taking into consideration current and latent needs (Cronemyr, 2007). For determining external customers' requirements, tools such as the Kano model are useful (Kano, 2001; Bergman and Klefsjö, 2010).

Process orientation is the second principle (e.g. Palmberg, 2009; Bergman and Klefsjö, 2010). This principle is present when organisations focus on business processes instead of their functional structure or the hierarchy within the organisation (Hellström and Eriksson, 2008; Kohlbacher and Gruenwald, 2011). Process orientation can be strengthened by the use of ISO9000 and the implementation of process management (e.g. Poksinska et al., 2003; Casells et al., 2012; Cosimato and Troisi, 2015). This principle enables improvements in the performance of organisations, reduces conflict and encourages a stronger integration and coordination within them (McCormack and Johnson, 2000; Lockamy and McCormack, 2004). A process orientation view allows individual actions to be seen as links in a much longer sequence of activities that add value for a customer and enable the crossing of traditional functional barriers (Hellström and Eriksson, 2008).

Process orientation and the implementation of process management should be supported by another principle, management commitment (e.g. Hinterhuber, 1995; Cronemyr, 2007; Paim et al., 2008; Palmberg, 2009; Kohlbacker and Gruenwald, 2011). Management commitment should be applied when managing the business using process management, and not only the implementation of the methodology (Hammer, 2007; Kohlbacker and Gruenwald, 2011). To ensure the success of this principle of process management, it is suggested to establish a person with deep knowledge of the process approach to take the leadership and responsibility for the advancement of process management across the entire company (Hammer, 2007; Kohlbacher and Gruenwald, 2011). Deming (1994) and Flynn et al. (1995) argue that top management commitment is a critical success factor for practices of quality management. Flynn et al. (1995) explain that management commitment has a great impact on all other principles related to quality management. Therefore, Deming (1994), Andersson et al. (1994) and Flynn et al. (1995) state that management needs to take responsibility for leadership and drive the required actions within the organisation.

The fourth principle of process management is structure and systematisation (Lee and Dale, 1998; Biazzo and Bernardi, 2003). Deming (1994) explains that a systems view should be supported by management, who need to direct the efforts of the entire system and ensure that they give directions for the system to move towards its strategic goals. The systems view includes not only the current state of an organisation but also its future and environment. The consideration of the future, as mentioned by Deming (1994), should include lifelong learning for employees. Deming (1994) also mentions that an organisation that works as a system needs to constantly scan its environment to identify the needs for innovation and competitors. By using process management, organisations are viewed in a more systemic way, with a structure based on the flow of the processes and not the functional organisation (Hellström et al., 2010). Process management aims to build structures in companies with processes, process owners and teams (Palmberg, 2009). These processes, as well 
as the relationships between them, need to be understood in order to gain a systemic view (Palmberg, 2009). Furthermore, Palmberg (2009) explains that processes and the relations between them need to be in line with the company's strategy in order to improve business performance. Moreover, it is important to understand that process management tools and efforts should be applied to the entire system and not only to specific processes (e.g. Palmberg, 2009; Cronemyr and Danielsson, 2013). The customer focus principle of process management also supports this systems thinking because it ensures that the processes of the company are developed in such a way that they can satisfy customer needs (Cronemyr, 2007; Palmberg, 2009).

The fifth and final principle from process management that I consider in my thesis is the involvement of everyone. This refers to the involvement of employees, customers and suppliers. Krajcsák (2019) explains that the success of the implementation of TQM initiatives in organisations can fail due to a lack of employee commitment. Krajcsák (2019) further states that employee commitment is not dependent on other TQM principles, but other principles are based on employee commitment. Hence, employee commitment is a decisive factor for the success of TQM and can have a positive effect on other decisive factors. Deming (1986) explains that, for a transformation to take place, everybody in the organisation needs to work to accomplish the transformation. Furthermore, Andersson et al. (1994), inspired by Deming (1986), mention that human resources, strategic management, purchasing and process control should facilitate the management of an organisation's processes. Moreover, Andersson et al. (1994) explain that this management should include and affect both the suppliers and customers of the organisation. Deming (1994) mentions that it is the responsibility of management to ensure the communication of the transformation that is to be made in the organisation and give directions on the actions required to achieve a shared vision of this goal. Flynn et al. (1995) mention that part of the infrastructure required to implement practices of quality management consists of customer relationships, supplier relationships and management of the workforce. Customer relationships can be achieved by frequent contact and the gathering of customer feedback. These elements, according to Flynn et al. (1995), allow an organisation to properly understand the needs and desires of their customers. Supplier relations should be long term to ensure the delivery of good-quality products and services for the processes (Flynn et al., 1995). Finally, Flynn et al. (1995) stress that the workforce needs to be onboard, have a positive attitude towards the changes required and a focus on the organisational goals. Furthermore, they explain that knowledge about the goals is essential for the employees to work towards achieving those goals.

\section{Implementation of process management}

Process management is a methodology based on the four-step cycle presented by Deming (1994), in which the phases are: Plan, Do, Study and Act. Some researchers have provided models for describing the use of process management. Bergman and Klefsjö (2010), for example, propose four steps for describing the process management methodology. The first step, organise for improvement, involves the establishment of important guidelines for process management. This goes hand in hand with the Plan phase in the cycle. During this step, process owners are appointed by management. These process owners are the people responsible for the development and improvement of the process. The second step is understanding the process and corresponds to the Do phase of the cycle. The authors argue that in this step it is important to identify who the customer is and what their requirements are, and specifically what creates value for them. This will provide the necessary information to discover what the expected outcomes are and how to keep the customers satisfied.

In this second step, several tools are used, such as process mapping. This tool will be further explained later. The third step is to observe the process and is in line with the Study phase of the cycle. This step involves measuring the processes, in terms of quality (customer satisfaction), and use of resources, such as materials and time, among others. The importance of this step is that it allows a determination of the status of the companies and helps to identify the areas where 
improvements are needed. The fourth and final step is the improvement itself and is connected to the Act phase of Deming's cycle. One of process management's most important pillars is continuous improvement. This step is thus of great importance for the methodology and presupposes a holistic view of the organisation.

Paim et al. (2008) explain that three main task groups can be identified in process management methodology: designing processes, managing everyday processes and fostering process-related learning. These task groups are explained below.

a. Process design task group: the tasks in this group involve an understanding of both the internal and external environments, and setting strategy, goals and approaches. This group includes ensuring the sponsorship for change, selecting the processes, forming process teams; and developing the as-is process among others. Process mapping is one of the tools that can support this group of tasks.

b. Managing everyday process: this group of tasks is in charge of taking care of the processes. They involve the allocation of resources, the supervision of progress and control of the results, among others. Control charts are an example of the tools used in this group for the monitoring and controlling of process execution.

c. Fostering learning: The tasks in this group have a monitoring nature. They include the measuring and monitoring of historical performance, as well as recording the collected data. This group is supported by tools such as information systems and benchmarking.

The model described by Berman and Klefsjö (2010) and the group tasks mentioned by Paim et al. (2008) are relevant for determining the actions needed to incorporate process management into an organisation. However, it is also important to be aware of the importance of implementing process management methodology in the right order. Therefore, many researchers have focused on developing maturity models for this methodology (Harrington, 1991; Lockamy and McCormack, 2004; McCormack, 2007; Rohloff, 2011; Cronemyr and Danielsson, 2013). These maturity levels are based on both theoretical and practical observations on process management, and all of them use a process orientation.

In this thesis, I use the maturity model presented by Cronemyr and Danielsson (2013) as a starting point. This model takes influences from the models presented by Harrington (1991), McCormack (2007) and Wheeler (1997) and their own experiences. In their model, "Process Management 1-2-3", Cronemyr and Danielsson explain that there are three steps an organisation needs to follow in order to successfully implement the process management methodology.

The first step is process development, which requires management to have process awareness to be able to establish processes. This step includes actions such as the achievement of management commitment, the establishment and documentation of the processes, and the designation of process teams and owners. Additionally, these authors mention the importance of having established structures for maintaining and updating the process. At the end of this step, the processes should be established, structured and measurable. Rohloff (2011) suggests that process maps should be based on interviews with process owners, process employees and the head of the business units.

Once the processes are established within an organisation, the second step of their model can be undertaken. Cronemyr and Danielsson (2013) argue that established processes are needed because they provide a stable baseline from which the processes can be improved. In the process improvement step, the processes should be improved based on facts. Therefore, it is important to establish goals and ways to measure the processes so that it is possible to gather data and identify problems or improvement opportunities. Once problems are detected, the root causes should be identified to enable improvements in the processes, using tools such as cause-effect diagrams and 
correlation diagrams (Doggett, 2005). For dealing with the improvements, it is important to develop and establish controls that alert managers when the process is not working as expected. It is also important for the processes to be alive. This means that it should be possible to update them when needed and that there should be a culture that strives towards continuous improvement.

The third and final step is process control. In this step, the improved processes are taken to a higher level: adaptable processes. The process is expected to work closely with the customer and to be flexible and proactive. In this step, tools such as statistical quality control are used to identify alarms in the processes more quickly.

In this thesis, I base my approach on a combination of what is exposed in the four-step model of Bergman and Klefsjö (2010), the process management tasks introduced by Paim et al. (2008) and the three-step maturity model from Cronemyr and Danielsson (2013). These are presented in Table 2.

Rohloff (2011) conducted a study in a multinational company which has proved to be successful in the implementation of process management. The author considers that, for process management to be successfully implemented, nine topics should be involved. These are explained below.

- Process management organisation: This topic deals with the designation of the roles in the processes and the designation of responsibilities.

- Process portfolio: in this topic, the processes with a greater need for standardisation and optimisation should be selected and prioritised. It is on these processes that the implementation should focus first.

- Process documentation and standardisation: all processes in the organisation should be developed consistently and for the entire organisation.

- Process performance control: key performance indicators and metrics should be established. They should be based on the goals and strategies of the company.

- Process management maturity assessment: there should be a periodic assessment of the process management maturity of the company and improvement measures should be implemented when needed.

- Methods and tools: standard tools and methods for the operations of the processes should be established.

- Communication: objectives, roles and responsibilities should be provided to key people in the organisation. They should also be provided with the progress of process management to create awareness within the company and support the implementation of the methodology.

- Qualifications and training: competency development should be ensured for the people involved with process management. This training should be developed in line with the needs of the people involved in the implementation, and its success must be verified.

- Target setting and incentives: The processes should be harmonised and standardised, and performance goals should be set for them. There should also be process target agreements related to incentives.

These topics are embedded in the process maturity models shown in Table 2 . The company in the study performed by Rohloff (2011) also refers to the implementation of Business Process Management (BPM). It is not uncommon to see this combination of concepts in the literature. Therefore, when referring to process management, it is important to mention BPM. These two methodologies can be confused with each other, given that the concepts developed in one can be applied to the other. For example, the definition of process used for both is based on research by the same scholars (e.g. Harrington, 1991; Davenport, 1993; Hammer and Champy, 1993). The use of the same definitions may cause certain difficulties in separating the two methodologies. Paim et al. (2008) refer to the difference between process management and BPM. The authors explain that BPM has its origins in operations management, while process management emerged from Total Quality Management and other theories, methodologies and movements such as the Theory of 
Constraints, the Toyota production system, knowledge management and benchmarking. Furthermore, Paim et al. (2008) mention that BPM methodology is much broader than process management. They mention that BPM includes more elements, such as enterprise resource planning and economic analysis. The origins of process management and BPM can be seen in Figure 9. Chang (2006) explains that, besides their origins, another difference between the two concepts is the goals embedded in their core theories. Within BPM, business process reengineering is one of the core theories associated with the concept, which has cost reduction as its primary goal. In contrast, process management, based on TQM theories and using methodologies such as Six Sigma to support it, has quality improvement as the primary goal.

Table 2. A process maturity model.

Based on Paim et al. (2008); Bergman and Klefsjö (2010) and Cronemyr and Danielsson (2013).

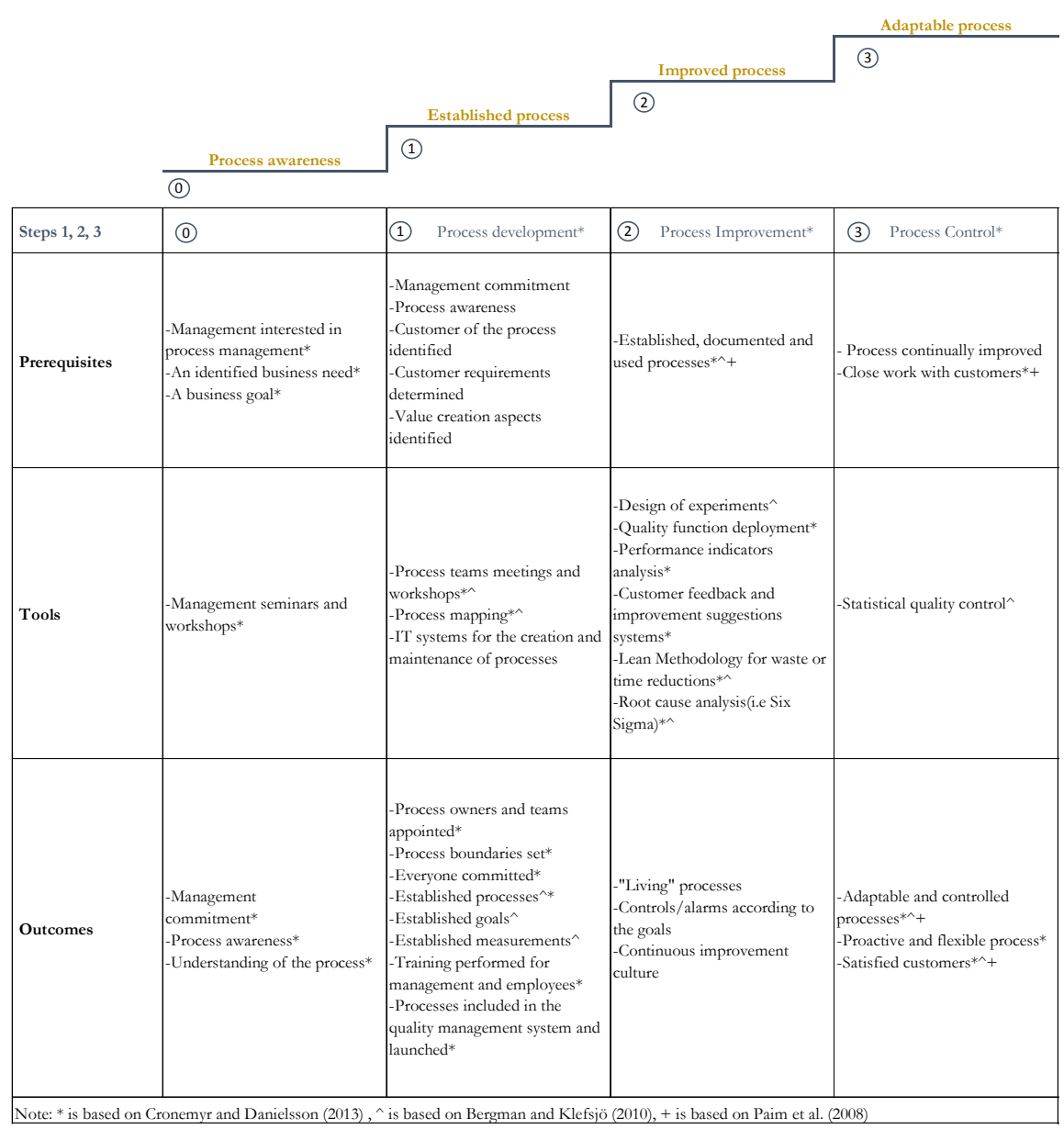




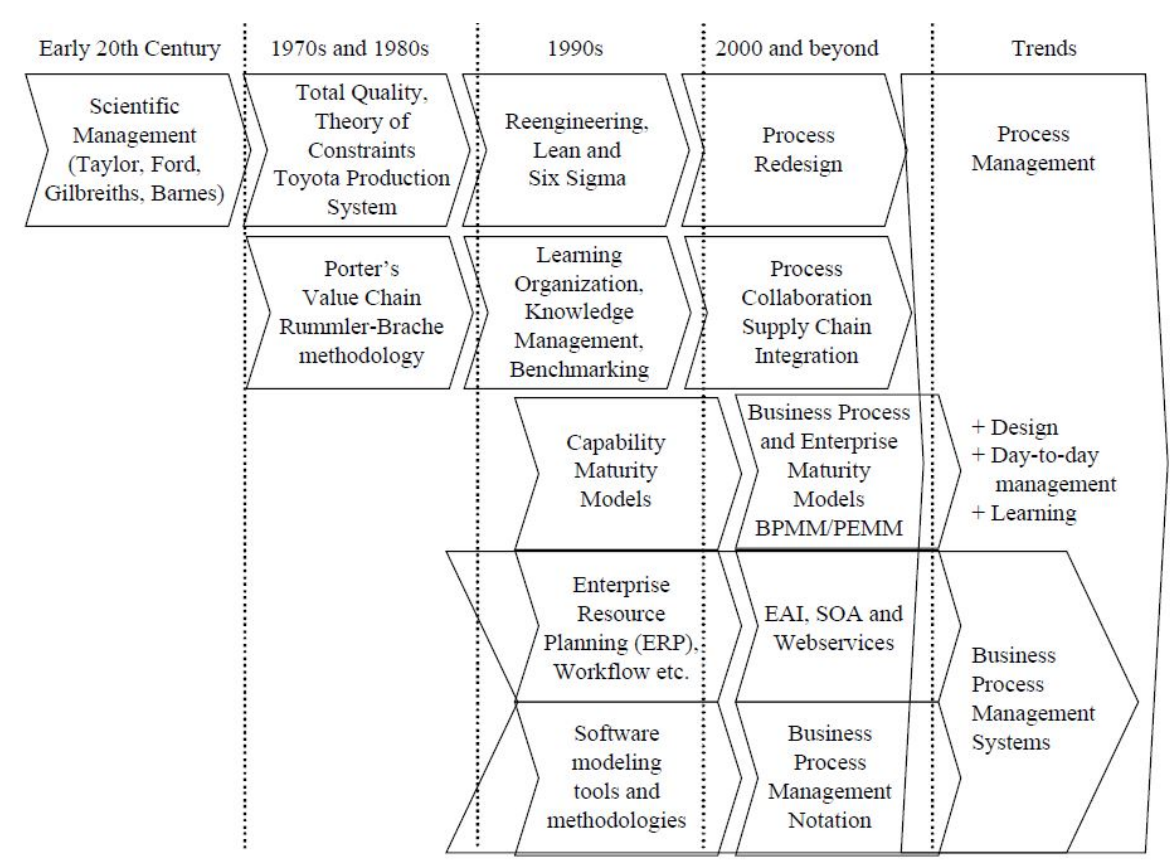

Figure 9. Process management conceptual timeline.

Taken from Paim et al. (2008).

\subsection{Process management in the road freight transport sector}

Näslund (2002) states that a process orientation can be the best means for improving efficiency and effectiveness in logistics processes. Similarly, Brah and Lim (2006) state that, within TQM, process management and customer focus have the potential to improve business performance. Bellah et al. (2013) confirm that TQM practices such as customer focus have positive effects on the performance of logistics operations. Furthermore, Mangan and Christoffer (2005) explain that logistics management, to which road freight transport belongs, is flow-oriented and that, by focusing on processes, logistics companies can obtain value creation in their operations.

De Bruin and Doebeli (2014) developed a study of a large Australian road transport company. The authors identified a series of changes that influenced the company. Among these changes was the organisational structure, which transformed from a functional structure into a structure with a process orientation involving process leaders and teams. They concluded that the use of process management can increase customer satisfaction, improve strategic planning, improve strategic deployment, increase the capabilities of employees and improve the reputation of the company.

Božić et al. (2014) studied some of the elements of process management methodology by analysing the implementation of BPM in a logistics company. They state that having a structure focused on processes and designing the processes according to customers' needs improves the transparency of the processes. This in turn enables the quantification of impacts by monitoring changes in each activity and process and the interactions between processes. 


\subsection{Process management for enhancing environmental sustainability}

The literature suggests that process management and its principles can support environmental initiatives. Nevertheless, research on the ways in which process management can support environmental sustainability is in its early stages. Hall and Wagner (2012) mention that companies employing management by processes have a more positive relation to environmental sustainability than those without this kind of management. Garvare and Isaksson (2001) conclude that process management provides a systematic view that supports environmentally sustainable development. Isaksson and Garvare (2003) suggest that this systematic view allows the establishment of performance indicators that measure environmental sustainability. Furthermore, Hervani et al. (2005) mention that environmental performance measures could be included in 'Balanced Scorecards'.

Isaksson (2006) proposes a management system that combines Total Quality Management and sustainable development. Furthermore, ISO 14000, a certification for environmental management systems which helps organisations to manage their environmental responsibilities, is based on a systematic approach. Poksinska et al. (2003) mention that ISO 14000 can be supported by a process orientation, one of process management's principles. Cassels et al. (2012) add to this statement by concluding that process management is a key factor in the implementation of ISO 14000. Ghose et al. (2009) see a potential in using process orientation to support environmental sustainability by establishing assessments of greenhouse emissions based on a process perspective.

There are additional findings in the BPM literature that can be connected to process management due to the connections between the two methodologies. Houy et al. (2010) mention the emergence of Green Business Process Management (GBPM) as a new research discipline. GBPM is a combination of BPM and environmental aspects. Houy et al. (2010) mention that common tools within BPM can support resource efficiency for achieving environmental sustainability. This resource efficiency can be obtained by identifying and measuring the waste within each step in a process and estimating the entire consumption of resources for each process. Similarly, Recker et al. (2010) present a process analysis approach for determining the carbon footprint of each process. They suggest that it is possible to improve processes and organisations in terms of environmental effect by understanding the carbon emissions at a process level.

Houy et al. (2010) identify two challenges in the implementation of BPM for enhancing environmental sustainability. The first challenge is the conflict that may exist between the reduction in costs, which is a target for BPM, and the striving for environmental sustainability, which can sometimes increase the costs. The second challenge is the lack of experience in process management, which is a challenge for its implementation to enhance environmental sustainability.

\subsection{Road Freight Transport}

Commonly, logistics is usually referred to the storage, the distribution and transportation of goods. However, the concept of logistics management involves much more. According to the Council of Supply Chain Management Professionals (CSCMP, 2019), logistics management is the part of supply chain management in charge of the planning, implementation and controlling of forward and reverse flow. It is also responsible for the storage of goods, services and all required information from the point of origin to the destination. In other words, logistics management is an integrating function that coordinates and optimises all logistics activities within the supply chain. CSCMP states that logistics management activities include the transportation of goods, referring to both inbound and outbound transportation management, fleet management and the management of third-party logistics services providers.

The transportation of goods refers to the movement of goods from one place to another within a logistics system (Kohn and Huge-Brodin, 2008). The transportation of goods can be achieved by different modes, such as aerial, maritime, rail and road (McKinnon, 2010). McKinnon and Piecyk (2009) state that the road freight business sector involves trucks and heavy goods vehicles. They 
also claim that this business sector includes both companies whose core activity is the transportation of goods and companies from other business sectors that include transport-related activities for their own products. Additionally, they include in this business sector, companies from other sectors that transport their own goods, such as manufacturers that operate their own heavy vehicles to transport their products. In this thesis, I include only companies whose main activity is the movement of goods from one place to another. For this study I use the context of road freight transport, considering the operations and management aspects of these kinds of companies. In this thesis, I refer to the road freight transport sector as "the freight transport sector" since the study is limited to this mode of transportation only. I define it as follows.

The road freight transport sector is the business sector in charge of the movement of goods from one place to another by means of road transportation, including the operation, management and development of the companies dedicated to this activity.

In Sweden, most manufacturing companies outsource the transport of their goods to haulage companies. The Swedish haulage industry's turnover is approximately 160 billion SEK, which corresponds to approximately $4 \%$ of the nation's gross domestic product (Sveriges Åkeriföretag, 2019). The Swedish Association for Road Transport Companies (2019) reports a total of 10000 road transport companies in Sweden. The road freight transport sector, specifically, faces many challenges, one of which is its environmental impact (McKinnon and Piecyk, 2009). Transportation by heavy vehicles has contributed significantly to environmental issues due to the release of greenhouse gases that result in climate change. Therefore, in 2017 the Swedish government established a new goal for all domestic transport, including the road freight transport sector. The goal is that, by 2030 , Sweden will have achieved a reduction of $70 \%$ in all emissions with negative environmental impact (Fossil Free Sweden, 2018; Johansson, 2018). Currently, most products are not locally produced, which increases the amount of transport required. This can be explained by the fact that the cost of operating centralised production and distribution is lower for companies than having these operations in different locations, even when the transportation costs are higher (Oskarsson et al., 2003). Therefore, the road freight transport sector has grown over the past few decades and is expected to continue growing by 1.8\% per year between 2018 and 2040 (Fossil Free Sweden, 2018). The increase in the amount of transport, together with the environmental goals for the business sector represent challenges for both the operation and strategies of the companies within this business sector.

\subsection{Environmental sustainability}

Sustainability is a concept that has existed for more than three decades, and refers to not overutilising resources in order to reduce the negative impact on future generations (Brundtland, 1987). This concept has been divided into three aspects: economic sustainability, social sustainability and environmental sustainability. The latter aspect refers to environmental resources and the way in which we humans influence them. Over the years, the negative environmental impact of humans has been significant. For this reason, we are now working towards the reduction of our environmental footprint. In Sweden, the government has adopted a set of 16 environmental objectives for achieving the nation's generational goal, which is a guide for environmental action at all levels of society (Swedish Environmental Protection Agency, 2018). Therefore, the adopted objectives apply to all sorts of companies, including those in the road freight transport sector. These objectives are shown in Figure 10. 


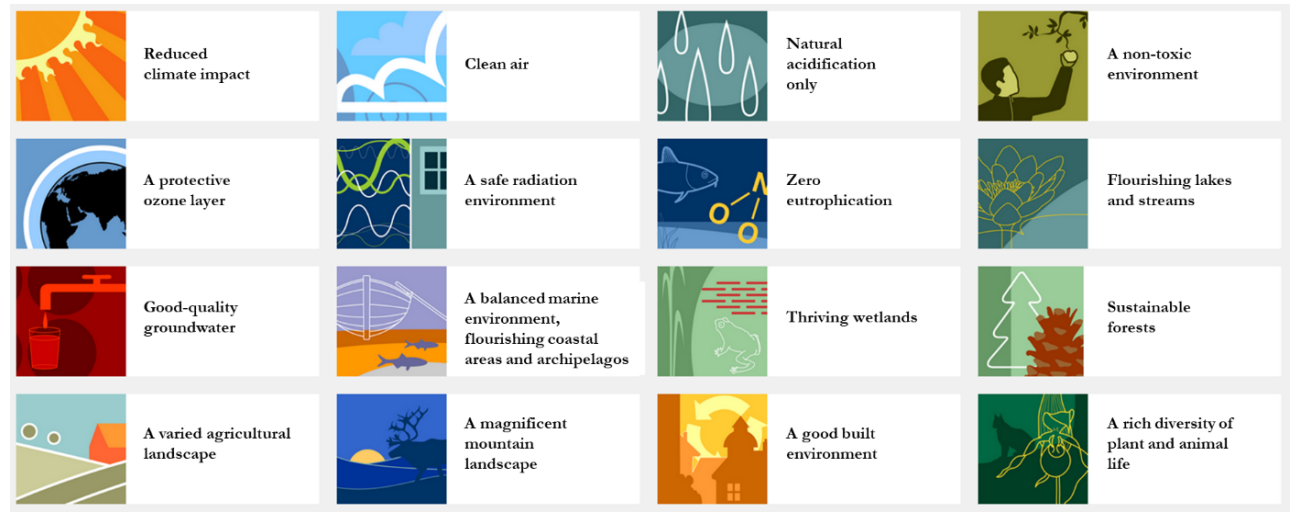

Figure 10. Swedish environmental objectives.

Taken from the Swedish Environmental Protection Agency (2019).

Research has focused on the reduction of the environmental footprint in many fields. One of these is the logistics sector, which produces approximately $75 \%$ of a company's carbon footprint (CSCMP, 2019). Within logistics, the freight transport sector is one of the most damaging for the environment (e.g. Oskarsson et al., 2013; Evangelista et al., 2017). Therefore, sustainable transport has been catalogued as a priority for the European Union, resulting in new research on the area (Márquez-Ramos, 2015).

Within logistics research, green logistics is the discipline that studies the opportunities to reduce environmental impact, and transport is included in this area (Srivastava, 2007). Several researchers have studied green logistics in transport (e.g. Richardsson, 2005; Aronsson and Brodin, 2006; McKinnon and Piecyk, 2009; McKinnon et al., 2015). The need for new solutions is clear, but the adoption of green initiatives has proved to be slow (Isaksson, 2012). Some researchers (e.g. Evangelista et al., 2013) argue that a lack of tools and knowledge for this greening is the reason for the slow adoption of green initiatives.

Green logistics is a term used within the logistics discipline and refers to topics such as corporate environmental strategies, systems for recycling involving logistics, green supply-chain management and city logistics (McKinnon et al., 2015).

\subsubsection{Greening}

As mentioned above, greening is a term that is used to describe the efforts made towards decreasing the environmental footprint of products and services. This term comes from the concept of green logistics, which describes logistics that concern environmental sustainability (Srivastava, 2007; Maack, 2012; McKinnon, 2010). For example, companies that have high environmental ambitions and strive towards increasing their environmental sustainability can be considered as companies that are going green. In this thesis, I will use the following two distinctions within the concept of greening:

Companies going green: Companies that have made the active choice to become more environmentally sustainable.

The greening of a company: the process of becoming more environmentally sustainable.

\subsection{Environmental sustainability in the freight transport sector}

Current research into green logistics, specifically in road transport, includes new fuel systems, delivery options (e.g. Vakulenko et al., 2018; Wehner, J., 2018) and vehicle technologies. They have all proved to have the potential to reduce the environmental impact of the transport sector. However, there is still a need for a systematic tool to support such new efforts from a managerial perspective, specifically at a strategic level. 
In research, some efforts have focused on the operational and managerial aspects of freight transport. Some examples of this research include: load configurations (e.g. Wehner, J., 2018), the use of consolidation centres (e.g. Triantafyllou et al., 2014; Björklund et al., 2017) and the coordination between different actors in the transport operations (e.g. Sallnäs, 2016). Other researchers have focused on the different environmental practices within the logistics sector. McKinnon (2010) presented a comprehensive framework for reducing CO2 emissions. Martinsen and Huge-Brodin (2014) took a stance within this framework and other research (e.g. Sarkis et al., 2004; Wolf and Seuring, 2010; Wejers et al., 2012) to present a list of environmental practices that have been detected in companies, involving the offering and buying of logistics and transport. The list is presented in Table 3 .

Table 3. Environmental practices.

Based on Martinsen and Huge-Brodin (2014).

\begin{tabular}{|c|c|c|}
\hline $\begin{array}{l}\text { Environmental } \\
\text { practice }\end{array}$ & Definition & Effect on the environment \\
\hline $\begin{array}{l}\text { Mode choice and } \\
\text { intermodal } \\
\text { transportation }\end{array}$ & $\begin{array}{l}\text { The transportation is performed using a } \\
\text { combination of modes, such as aerial, } \\
\text { maritime, road and/or rail. }\end{array}$ & $\begin{array}{l}\text { Different modes of transport vary in } \\
\text { the amount of emissions they } \\
\text { liberate to the environment. }\end{array}$ \\
\hline $\begin{array}{l}\text { Logistics system } \\
\text { design }\end{array}$ & $\begin{array}{l}\text { Efforts involving distribution design, } \\
\text { studying the whole supply chain for the } \\
\text { development of solutions that are better for } \\
\text { the environment. }\end{array}$ & $\begin{array}{l}\text { Better choices in the utilisation of } \\
\text { the length of the haul and the } \\
\text { handling factor. }\end{array}$ \\
\hline $\begin{array}{l}\text { Transport } \\
\text { management }\end{array}$ & $\begin{array}{l}\text { Involves a decrease in the empty running of } \\
\text { the vehicles, freight consolidation, route- } \\
\text { planning, and improved fill-rates of vehicles. }\end{array}$ & $\begin{array}{l}\text { Increased efficiency of vehicle usage } \\
\text { will in turn result in more } \\
\text { environmentally responsible results. } \\
\text { Lower emissions per kg or volume } \\
\text { of loads. }\end{array}$ \\
\hline $\begin{array}{l}\text { Vehicle } \\
\text { technology }\end{array}$ & $\begin{array}{l}\text { Refers to energy efficiency, for example by } \\
\text { developing better technology for the engines } \\
\text { or aerodynamic design of the vehicles, which } \\
\text { lead to more efficient utilisation of energy. }\end{array}$ & $\begin{array}{l}\text { A more efficient utilisation of energy } \\
\text { will decrease fuel consumption and } \\
\text { in turn the emissions from vehicles. }\end{array}$ \\
\hline $\begin{array}{l}\text { Behavioural } \\
\text { aspects }\end{array}$ & $\begin{array}{l}\text { Improved driving behaviour and the } \\
\text { utilisation of eco-driving skills. Training for } \\
\text { vehicle drivers to increase their skills in } \\
\text { reducing energy consumption and making } \\
\text { more environmentally friendly decisions } \\
\text { when driving. }\end{array}$ & $\begin{array}{l}\text { Developing better driving habits will } \\
\text { reduce gear changing and the level } \\
\text { of } \mathrm{CO} 2 \text { emissions by maintaining } \\
\text { better speed control and having } \\
\text { better techniques for braking. }\end{array}$ \\
\hline Alternative fuels & $\begin{array}{l}\text { The utilisation of fuels that have lower } \\
\text { environmental impact (carbon intensity) } \\
\text { compared to common alternatives. }\end{array}$ & $\begin{array}{l}\text { Options with lower carbon intensity } \\
\text { will have a lower environmental } \\
\text { effect. }\end{array}$ \\
\hline $\begin{array}{l}\text { Environmental } \\
\text { management } \\
\text { systems }\end{array}$ & $\begin{array}{l}\text { Use of environmental management systems, } \\
\text { such as ISO } 14000 .\end{array}$ & $\begin{array}{l}\text { Better communication of the } \\
\text { environmental efforts and goals } \\
\text { along the supply chain. Results in a } \\
\text { proven lower environmental risk for } \\
\text { customers. }\end{array}$ \\
\hline Choice of partners & $\begin{array}{l}\text { Active choice of suppliers and customers } \\
\text { according to their environmental aspects. }\end{array}$ & $\begin{array}{l}\text { Better choices, environmentally, } \\
\text { along the supply chain. }\end{array}$ \\
\hline Emission data & $\begin{array}{l}\text { Measurement and share of emissions } \\
\text { between different parts of a supply chain; for } \\
\text { example, the transporter and the shippers. }\end{array}$ & $\begin{array}{l}\text { Better control of emissions and } \\
\text { opportunity to offer that } \\
\text { information to customers. }\end{array}$ \\
\hline
\end{tabular}


Other researchers (e.g. Sallnäs, 2016; Wolf and Seuring, 2010) argue that, for the implementation of environmental practices within logistics companies, there is a need for coordination between the stakeholders. Seuring and Wolf (2010) state that the stakeholders, specifically the firm and its customers, are aware of the importance of environmental sustainability and that customer demand for environmentally friendly solutions is increasing. However, they emphasise that there is still a prioritisation of minimising the costs of services. They argue that, in cases of trade-offs between environmental aspects and financial aspects, customers choose options with the best economic conditions. Lieb and Lieb (2010) concluded in a study developed within large companies that there is a growing sensitivity to issues concerning sustainability among the customers of third-party logistics companies. Furthermore, they suggest that sustainability issues are becoming more relevant within the transport market to the extent that they will become a significant differentiation factor.

\subsection{Process management, environmental sustainability and road freight transport}

This intersection between the three domains corresponds to the star in Figure 2. The literature on the use of process management in the road freight transport business sector for enhancing environmental sustainability is very limited.

Azevedo et al. (2012) state that, among the quality management methodologies, there are some that enable programmes of environmental sustainability for logistics processes. These authors conducted a study on logistics companies and found that the use of some QM methodologies led to enhanced environmental performance. Mitra (2014) states that the implementation of environmental management systems, such as ISO 14000, is an effort that is usually undertaken voluntarily and proactively by companies. Mitra (2014) explains that other certifications, like ISO 9000, are also applied voluntarily by companies and that both certifications require high management commitment and employee participation to succeed. Both requirements are present in the QM methodology of process management. Moreover, and specifically for freight transport, Cosimato and Troisi (2015) studied a large, global company that bases its core activities on ISO 14000 and ISO 9000, with a process focus. These authors conclude that the use of ISO 9000 had a positive effect on the company's environmental initiatives and increased its competitiveness.

I have found this intersection to be very limited and fragmented in the literature. Therefore, I developed this research with an exploratory approach in order to contribute to filling the existing research gap. The method used for my research is explained in the next chapter. 


\section{RESEARCH METHODOLOGY}

In this chapter, I describe my research approach, followed by the project upon which the thesis is based. Later, I explain the methods used for developing the purpose and designing the research questions. I also present each of the data-collection methods used for the papers appended to the thesis, which include both passive and active forms of data collection. Finally, I present the method used for analysing the data. 


\subsection{Research approach}

This thesis was developed using a qualitative approach and is written in the form of a compilation. During the development of the thesis, I performed a literature review at the beginning of each included article. This was followed, for two of the papers, by the data collection at each of the companies. Finally, the findings from the empirical data were compared to the results found in the literature. However, my interest lies in adapting process management research to the needs of the business sector and its ways of working. Therefore, I develop my thesis based on the empirical data gathered in the cases and support it with what is presented in the. Thus, I consider that the overall approach of my thesis is inductive in character, even though some parts of it incline towards a deductive research character.

Paper I is based in theory and is intended to evaluate and present the approaches of process management and Lean, both from quality management, for enhancing environmental sustainability.

Paper II is based on a literature review and data collection for two cases at two different companies. From these sources of data, the analysis was performed.

Paper III is based mostly on the findings from the data collection at the companies and previous knowledge of the researchers. Literature found during the development of Papers I and II was also considered for this paper. I used an action research approach to develop the study. This approach is explained in the following section.

\subsection{The origin of the thesis: the research project}

To understand the choice of topic for my thesis, I consider it important to introduce the research project from which it was born. This thesis is part of a research project called "Process management for sustainable freight transport". The project began in September 2016 and is ongoing.

Three researchers are working actively on this project. Two of them are thematic experts, one within the green logistics discipline and the other within process management. I am the third researcher, a $\mathrm{PhD}$ candidate in the area of process management within the discipline of quality management. Additionally, two Swedish companies are participating in the project as collaborators; it is mainly within these companies that the data collection is taking place. The companies are two road transport businesses, one operating in Norrköping and the other in Malmö.

The project grew out of the potential found in the discipline of Quality Management for using it in the context of logistics. This potential was discovered due to the merging of two divisions at Linköping University, the Quality Management Division and the Logistics Division. The purpose of the research project is to encourage more proactive work for sustainability within the logistics sector in Sweden. Specifically, the aim of the project is to research how well-established methods and principles within process management can be used for achieving this purpose.

The research project was divided into three phases, as shown in Figure 11. These phases were designed in such a way that they could achieve the purpose of the project and cover the areas of interest within it. This thesis covers the work from the first phase, service processes, and the second phase, improvement processes. The third phase of the project will study development processes for a doctoral thesis. The purpose and research questions of this thesis arise out of the first two phases of the project.

\begin{tabular}{|c|c|c|c|c|c|c|c|c|c|c|c|c|c|c|}
\hline & \multicolumn{2}{|c|}{2016} & \multicolumn{4}{|c|}{2017} & \multicolumn{4}{|c|}{2018} & \multicolumn{4}{|c|}{2019} \\
\hline & Q3 & $\mathrm{Q} 4$ & Q1 & $\mathrm{Q} 2$ & Q3 & $\mathrm{Q} 4$ & Q1 & Q2 & Q3 & $\mathrm{Q} 4$ & Q1 & Q2 & Q3 & $\mathrm{Q} 4$ \\
\hline & & & & & & & & & & & & & & \\
\hline \multirow{3}{*}{$\frac{\pi}{2}$} & \multicolumn{6}{|c|}{ Phase 1. Service processes } & & & & & & & & \\
\hline & & & & & \multicolumn{6}{|c|}{ Phase 2. Improvement processes } & & & & \\
\hline & & & & & & & & & \multicolumn{6}{|c|}{ Phase 3. Development processes } \\
\hline
\end{tabular}

Figure 11. Timetable for the research project 


\subsection{Action Research}

According to Herr and Andersson (2014), action research is inquiry that is conducted by or with insiders of an organisation, such as employees and management, rather than being done to or on them. The researchers involved in the project took an active part in the workshops. We contributed with ideas, recommendations and knowledge about process management and green logistics in order to be able to integrate both. As mentioned by Cronemyr (2007), based on Lewin (1946), the difference between traditional research and action research is that the first strives towards generalisable knowledge while the latter is more interested in achieving change. Westlander (2006) confirms that the difference lies in the kind of involvement of the researcher; in action research the researcher is an agent of change. Action research is interested in comparing the results of doing an action (after) with how it was initially was (before the action research was done). Lewin (1947) presents the "action in planned change", which is a pattern for basing planning on continuous learning from previous experiences (see Figure 12). In his pattern, a plan emerges from an idea. The idea needs a goal, a path to reach that goal, allocated resources and a strategy of action. When the idea has all of those elements, it becomes a general plan. This general plan is evaluated (recognisance) based on facts, and a first decision is made. Once the first decision has been made, there should be an evaluation of the results to ensure that the path towards the goal is being followed and to analyse whether the results were as expected. Based on this evaluation, a new decision is made for the next action. This second action should then be followed by another recognisance and a new decision should be made. This process of reconnaissance and decision making based on facts is then repeated until the goal is reached. I consider that this pattern allows for the enhancement of success opportunities to reach the goal because, for every action a new decision is taken based on the results of the previous action. This allows readjustments to the plan to ensure that the research is travelling along the right path for achieving its objective.

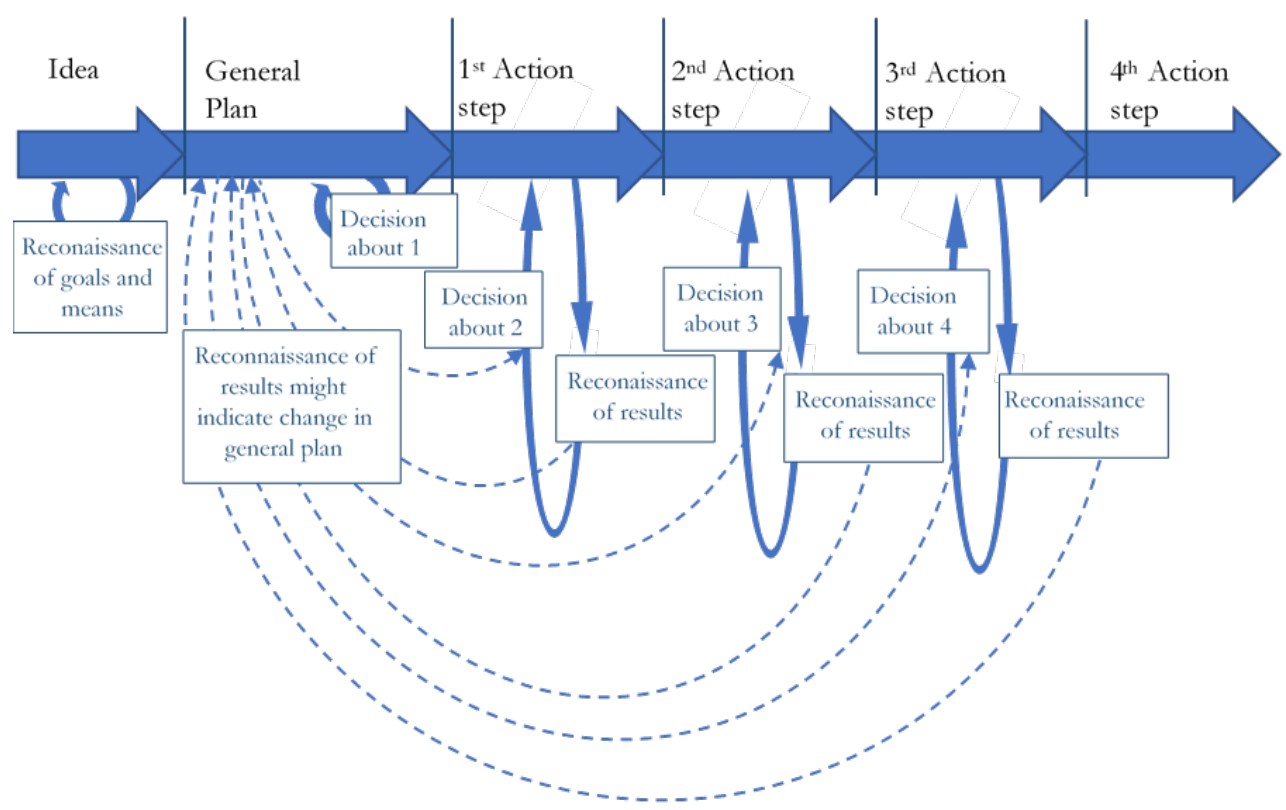

Figure 12. Action in planned change pattern. Re-drawn from Lewin (1947, p. 149). 
Action research contributes to the development of scientific knowledge while providing immediate practical solutions to problems for practitioners (Foster, 1972). With my thesis, I intend to contribute to research on Quality Management, but I also want to achieve immediate change for freight transport companies. This is the reason for including this research approach in this study. Aagaard Nielsen and Svensson (2006) mention that action research can be a way of improving the learning conditions for doctoral candidates by making the training more relevant, more challenging, useful and interesting. Hansson (2003) explains that this is done by actively participating in research and combining practical usefulness with theoretical understanding. Therefore, I am interested in using an approach that incorporates this form of research in my thesis. Furthermore, Evangelista and Sweeney (2014), two researchers focusing on green logistics, concluded after a study of the freight haulage industry that the use of case studies and action research could allow a deeper understanding and richer insights into the phenomena that are observed in the business sector.

Lewin (1947), who is considered the father of action research, has been strongly criticised by some academics over the years (e.g. Sanford, 1970). One consideration is that his definition of action research lacks democracy. The researcher plays a more authoritarian role and the practitioners have a more experimental nature. In my research, I use an action research approach. The reason for this denomination is that our collaboration with the companies has a more participatory nature. We, the researchers, are participating during the entire project and developing solution for the companies. We, the researchers, perform the analyses based on the findings, but the analyses are verified by the companies in meetings at the end of each phase. These meetings include separate meetings at each company and a joint meeting with both companies.

My research approach is, to some extent, based on the model presented by Ellström (2008). In this model, Ellström (2008) distinguishes between two interacting systems, the research system and the practice system. Both systems are cyclical and driven by problems which originate in either research or practice. In the model, each system includes basic activities, research activities such as data collection and analysis for the research system, and organisational action for the practical system. These basic activities gain input from theories based on previous research and/or experiences from practice. The two systems interact, and it is during this interaction that a conceptualisation and interpretation of the research object is achieved. The model is presented in Figure 13.

For my research, the practical system is represented by the cases of Haulier and Forwarder. The research system is represented by the two topical experts and me. In our study, both cases identified the need to enhance environmental sustainability in their companies. We, the researchers, identified the problem of a lack of tools for the road transport business sector to become more sustainable.

The starting-point theories for the cases were the results from previous changes involving environmental aspects and experiences from previous contact with academia. Our starting-point theories, as the researchers, were process management methodology and research in the field of green logistics.

We, the researchers, collected data and performed analyses based on this data and the theories. We then suggested changes for the practical system. These changes were adapted for and with the case companies, and were part of the interaction between the systems. Interactions between the two systems in my research included, but were not limited to, meetings, seminars and workshops. This last paragraph is the reason why I consider my research to only be based on this model to a certain extent. Our interaction with the companies is higher than in the interaction research that Ellström (2008) describes. The change is designed in cooperation between the companies and the researchers. However, to ensure the autonomy of the companies, each company decided which changes, if any, to apply, and how to apply them. We, as researchers, would then observe and document the change. 


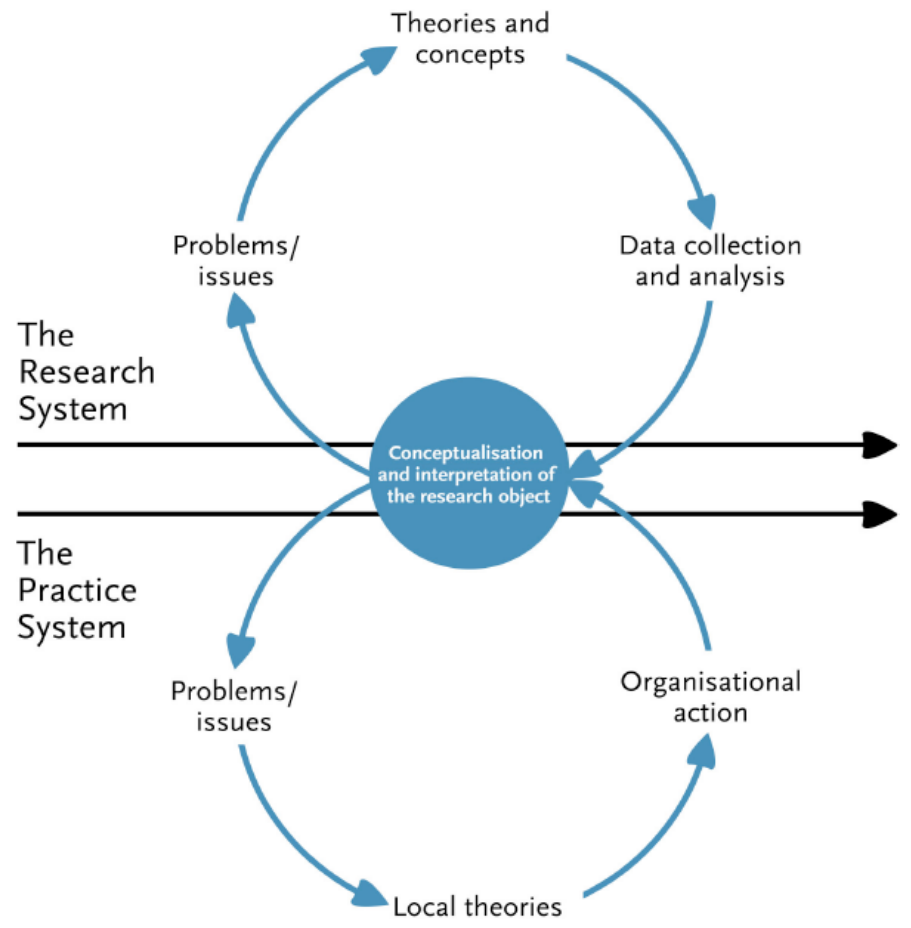

Figure 13. A model of knowledge creation through interactive research. Taken from Ellström (2008, p.5).

In traditional research, the researcher takes a passive role while in action research the researcher is a "change agent" (Westlander, 2006) and thus plays an active role. Huge-Brodin and Cronemyr (2019) present the various roles of the researcher in collaborative research (see Figure 14). My research is a mixed role between active and passive. I took an active role during the workshops, seminars, meetings, design of the actions and development of documents needed for the action. However, during the decision about which change to implement and how, I took an observer role, which was passive, in order to reduce the risk of affecting the results. Huge- Brodin and Cronemyr (2019) state that university PhD candidates usually take this kind of role when involved in action research. The reason for this categorisation is that the role is neither that of a passive observer, as it is in traditional research, nor as active as an "insider" of the company would have been. 


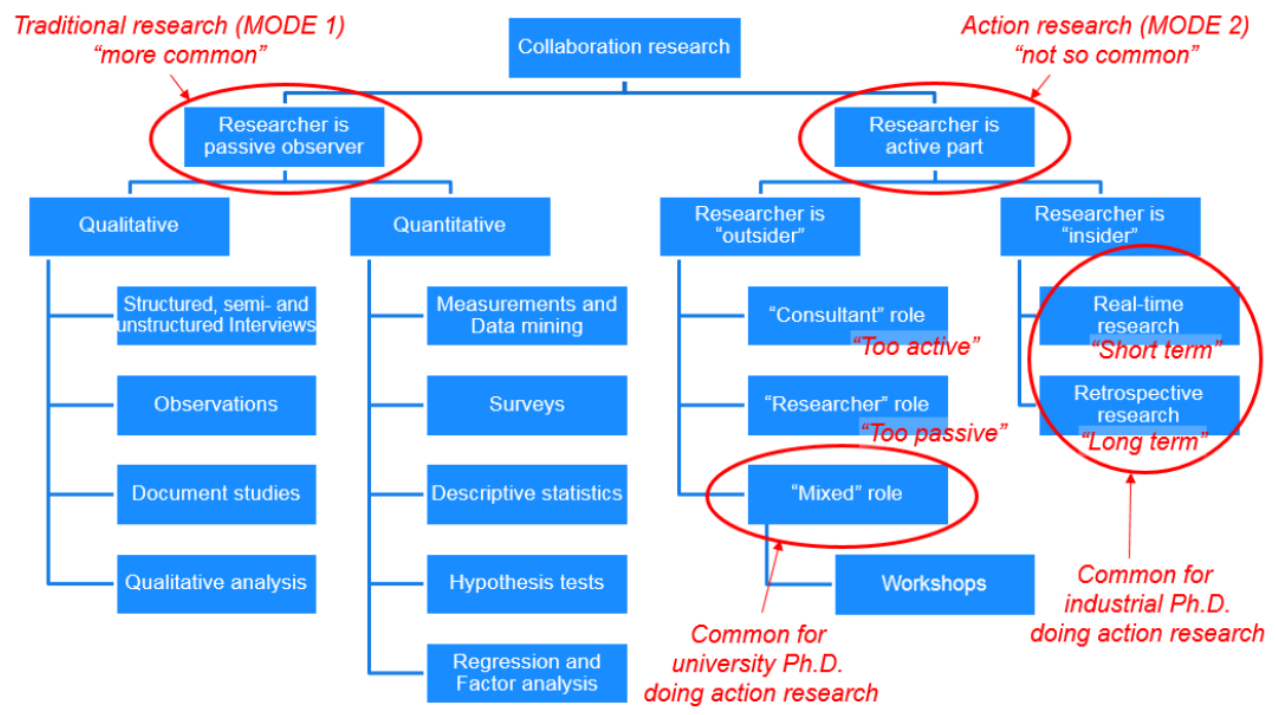

Figure 14. Methods in collaborative research.

Taken from Huge-Brodin and Cronemyr (2019, p.4).

\subsection{Development of purpose and research questions}

I designed the initial purpose and research questions for this thesis based on my own experience of research. My intention was to capture the most interesting findings from the data gathered so far within the project and connect them to the methodology of process management. These purpose and research questions were then reviewed in an iterative process with the two topical experts in the project, my supervisors.

\subsection{My contribution to the appended papers}

\section{PaperI.}

Navarro, P.; Cronemyr, P. (2018). Applying quality methods for achieving environmental sustainability in the freight transport sector: Reviewing Process Management and Lean. Presented at $21^{\text {st }}$ QMOD Conference, Cardiff 2018.

Contributions: This paper was presented at QMOD 2018, I was responsible for the design and development of all parts of the paper. The second author contributed to all parts of the paper by providing supervision and guidance for its development and improvement.

\section{Paper II.}

Navarro, P.; Cronemyr, P. and Huge-Brodin, M. (2018). Greening logistics by introducing process management- a viable tool for freight transport companies going green. Supply Chain Forum: An International Journal. Vol 17 (4). Doi: 10.1080/16258312.2018.1486141

Contributions: I had the main responsibility for the literature review and the data collection for both case studies. The results, analysis and conclusions were generated in collaboration with the other two authors. 


\section{Paper III.}

Navarro, P.; Cronemyr, P.; Huge-Brodin, M. (2018). How to implement green logistics: Using improvement processes for increasing environmental initiatives in freight transport companies. 21st International Conference in Excellence in Services. Paris, France.

Contributions: For this paper, I contributed to the data collection, results, analysis, discussion and conclusions for the paper, together with the other two authors.

\subsection{The literature reviews}

This thesis includes three papers. For each of them, a literature review was performed, as shown in Table 4. The role of the literature in each paper and in the thesis is as a basis for developing the research questions. Additionally, and since the thesis is more inclined towards an inductive approach, I expect the literature to be of a framing nature and as a means to compare the findings to previous research. Due to the exploratory nature of this thesis, the systematic literature review was an appropriate tool for beginning the process in a structured way. It allowed a familiarisation with the subject and each of the domains included in the thesis. The narrative literature review provided a good tool for the further exploration of the domains and to complement the systematic literature review. The two types of literature reviews used are explained below.

Table 4. Literature reviews for the thesis

\begin{tabular}{|l|c|c|c|}
\hline & \multirow{2}{*}{\begin{tabular}{c} 
Systematic \\
literature \\
\cline { 3 - 4 }
\end{tabular}} & \multicolumn{2}{|c|}{ Narrative literature reviews } \\
\cline { 3 - 4 } & reviews & Search strings and filters & Snowball approach \\
\hline Paper I & $\mathrm{x}$ & & $\mathrm{x}$ \\
\hline Paper II & $\mathrm{x}$ & & $\mathrm{x}$ \\
\hline Paper III & & $\mathrm{x}$ & $\mathrm{x}$ \\
\hline Thesis frame & & & $\mathrm{x}$ \\
\hline
\end{tabular}

\subsubsection{Systematic reviews}

For the second paper included in this thesis, I performed a systematic literature review (Tranfield et al., 2003) with the purpose of discovering what literature already exists in the intersections of the model in Figure 2. The reason for using this type of literature review is that my interest was in a specific subject (intersections), as well as the criteria for the selection of results (relevance to the relation of the domains). This literature review was especially useful as an initial exploration of the domains included in the conceptual model. The systematic review provided a structured method for exploring the different domains and their intersections. To ensure the high quality of this literature review, I reviewed the search string with two experts, one in process management and another in the area of green logistics, which in turn includes the domains of environmental sustainability and freight transport. The results were initially filtered by title. Later, they were filtered by abstract, findings and conclusions. The method used in this literature review is further explained in Paper II, and Figure 15 and Figure 16 summarise the results. 


\begin{tabular}{ll}
\hline Intersection & \multicolumn{1}{c}{ String } \\
\hline $\begin{array}{c}\text { Process management and } \\
\text { freight transport }\end{array}$ & $\begin{array}{c}\text { process management or business } \\
\text { process or activity flow or value } \\
\text { stream or quality management AND } \\
\text { goods transport* or freight* or } \\
\text { logistics. }\end{array}$ \\
$\begin{array}{c}\text { Freight transport and } \\
\text { environmental } \\
\text { sustainability } \\
\text { Process management and } \\
\text { environmental } \\
\text { sustainability }\end{array}$ & $\begin{array}{l}\text { logistics AND green or sustainab* or } \\
\text { process management or business } \\
\text { process or activity flow or value } \\
\text { stream or quality management AND } \\
\text { green or sustainab* or evironm* }\end{array}$ \\
\hline
\end{tabular}

Note: * is a wild-card

Figure 15. Strings for the systematic literature review.

Taken from Navarro et al. (2018a).

\begin{tabular}{lcc}
\hline Intersection & $\begin{array}{c}\text { Initial search, } \\
\text { \#articles }\end{array}$ & $\begin{array}{c}\text { After first } \\
\text { selection, } \\
\text { \#articles }\end{array}$ \\
\hline $\begin{array}{c}\text { Process management and freight } \\
\text { transport }\end{array}$ & 2768 & 85 \\
$\begin{array}{c}\text { Freight transport and } \\
\text { environmental sustainability } \\
\text { Process management and } \\
\text { environmental sustainability }\end{array}$ & 612 & 41 \\
\hline
\end{tabular}

Figure 16. Results from the systematic review.

Taken from Navarro et al. (2018a).

The systematic review undertaken for the second paper allowed an exploration of the domains and intersections illustrated in Figure 2. This exploration facilitated the design and development of the second systematic review. This second systematic literature review was used for Paper I, included in the thesis. For this paper, an approach using search strings and filters was applied as part of the literature needed for the analysis. This literature was complemented with a literature review using a snowball approach, which is explained in the following section. In the first approach, I conducted a search using the Scopus search engine, where I looked for relevant concepts and terminology present in the object of interest, with the use of search strings. I performed a first filter (filter A) for all the journal articles written in English in the areas of management, engineering and logistics. Later, I used a second filter (filter B), according to the titles and abstracts of the articles. The results of the search strings after each filter and the final results are presented in Table 5.

\subsubsection{Narrative reviews}

For Papers I and III, I used a snowball approach (Smith, 2012). In this way, I found new references in the articles I considered interesting and/or relevant among the results of the traditional narrative approach. This was an iterative process, which means that from those new references I then found others. For Paper I, I found a total of 17 articles and two books from the snowball approach. For Paper III, all the articles were the result of a snowball approach, beginning with articles previously considered relevant to the subject by the three authors. Additionally, other sources were found as a thesis frame using search strings for a narrative review and snowball approach (Smith, 2012). 
Table 5. Search strings and result articles for Paper I

\begin{tabular}{|c|c|c|c|c|c|}
\hline Search strings & $\begin{array}{l}\text { Research questions for } \\
\text { Paper I }\end{array}$ & \begin{tabular}{|l|} 
Initial \\
$\#$ \\
articles \\
\end{tabular} & $\begin{array}{l}\text { Filtered } \\
\mathrm{A}\end{array}$ & $\begin{array}{l}\text { Filtered } \\
\text { B }\end{array}$ & $\begin{array}{l}\text { Result } \\
\text { Articles }\end{array}$ \\
\hline "Process management" AND environm* & $R Q^{1}, R_{2}^{3}$ & 2043 & 367 & 61 & 3 \\
\hline $\begin{array}{l}\text { "Process management" AND environmental } \\
\text { sustainab* }\end{array}$ & $R Q^{1}, R Q^{3}$ & 11 & & 6 & 4 \\
\hline $\begin{array}{l}\text { "Process management" AND environm }{ }^{*} \\
\text { AND freight OR transport* }\end{array}$ & $R Q^{3}$ & 25 & & 4 & 3 \\
\hline $\begin{array}{l}\text { Lean OR Lean manufacturing AND } \\
\text { environm* }\end{array}$ & $R Q^{2}, R Q^{4}$ & 6878 & 1274 & 79 & 22 \\
\hline $\begin{array}{l}\text { Lean OR Lean manufacturing AND } \\
\text { environmental sustainab* }\end{array}$ & $R Q^{2}, R Q^{4}$ & 56 & 19 & 14 & 8 \\
\hline $\begin{array}{l}\text { Lean OR Lean manufacturing AND } \\
\text { environm }^{*} A N D \text { freight OR transport* }\end{array}$ & $R Q^{4}$ & 174 & 23 & 6 & 5 \\
\hline total results & 45 & & & & \\
\hline Repeated results & 9 & & & & \\
\hline Not available & 1 & & & & \\
\hline Total articles read & 35 & & & & \\
\hline \multicolumn{2}{|l|}{ *is a wild-card } & & & & \\
\hline
\end{tabular}

\subsection{The case study}

The empirical data collection was conducted at the two companies involved in the research project. The data used for Paper II was collected during the first phase of the project. The data for Paper III was mostly collected during Phase 2 of the project. For the collection, we used interviews, observations, documentation analysis and workshops. Table 6, Table 7 and Table 8 present a summary of the data collection, with a timetable.

\subsubsection{The cases}

Due to the nature of the research questions of the thesis, I use a multiple case study approach (Yin 2013) for this thesis. I have developed two case studies, each focusing on a different Swedish freight transport company. My intention with this research is to make a within-case analysis for each company and a cross-case analysis between them (Miles and Huberman, 1994).

\section{a. The case selection}

I intended to develop this research in close cooperation with the companies involved, by using an action research approach (Lewin, 1947). Therefore, the criteria for the selection of these companies were the availability of management, as well as the engagement and commitment of management towards the company's daily operations. Additionally, it was important, due to the purpose of this thesis, that the companies were environmentally proactive. This means that they needed to be willing to make efforts for the environment. Since I used an action research approach, it was also important that the companies were able to assign resources for the work required in the studies, including meetings and data collection. With these criteria in mind, and due to the interest shown by two Swedish companies, it was decided to perform two case studies, one at each company. The companies are described below. 


\section{b. The Haulier case}

The first case was developed at a company that I will refer to as Haulier for anonymity reasons. Haulier is a medium-sized Swedish company dedicated to goods transport. It was established eight decades ago has been managed by the founding family ever since.

Haulier operates mostly within Swedish territory, in the region Östergötland. The company has 100 employees, five of whom work in administration and the rest as drivers or mechanics. Haulier performs road-based freight transport, $40 \%$ of its transport is for a large logistics service provider and $60 \%$ is for direct customers.

This company has a reputation for providing high-quality transport, in terms of delivery times and handling of goods. The management of this company is engaged and committed to maintaining this reputation. Additionally, the management focuses on reducing the company's environmental effects. They have made several efforts towards this improvement in the past by participating in other research projects based at Linköpings University and creating environmental improvement projects of their own. The research project of which this thesis is a part is another of their efforts to become more environmentally sustainable.

\section{c. The Forwarder case}

The second case was developed at a company that I will refer to as Forwarder, again for anonymity reasons. Forwarder is a cooperative association of hauliers. The association currently has around 120 haulier members, employing more than 250 people. Additionally, it has 20 employees working in the administration of the cooperative association. The company is dedicated to the transport of goods by road. The company also offers other services, such as construction vehicles and the recycling of materials. The company operates mostly within Swedish territory but also undertakes some transport to other countries, such as Germany and Denmark. Among the company's customers, there are multinational companies and smaller Swedish service providers. This company strives towards innovation, high quality (in terms of delivery times and handling of goods), safety and good environmental thinking. The company has a strong management commitment and involvement in its operations. Additionally, it is also interested in maintaining a customer focus and achieving continuous improvement.

\subsection{The data collection methods}

\subsubsection{Interviews}

The nature of this case study was exploratory, and for this reason all the interviews performed at the companies were semi-structured and personal (Westlander, 1999; Yin, 2013). For each phase, I designed an interview guide based on the literature review findings, the researchers' previous knowledge and initial study visits to the respective case company. The interview guides were designed to flow from general questions to more specific questions related to the specific topics; these guides are included in Appendix I. For Paper II, the interviews were divided by theme, one series for process management and another for green logistics. For Paper III, there was no division according to the theme but the interviews were performed by me and one of the other researchers. I was the interviewer, together with the topical expert, at each of these interviews. I was responsible for asking the questions and the topical expert could ask additional questions if necessary. The duration of the interviews for Paper II was between 60 and 90 minutes and the ones for Paper III lasted between 40 and 80 minutes. A total of 15 interviews was conducted in the Haulier case study, 10 interviews for Paper II and five for Paper III. For the Forwarder case study, a total of 24 interviews was conducted, 14 for Paper II and ten for Paper III. The interviews were conducted with both operative and management personnel. The distribution of the interviews is detailed in Table 6 and Table 7. For the selection of interviewees, I considered suggestions made by management about the people who were more active or had most knowledge about the processes being studied. 


\subsubsection{Observations}

The observations were conducted during the study visits and additional meetings convened for the research project. Among the objectives for the observations, we focused on work routines, environmental awareness, commitment, existing documentation and the values and principles of each company. Among the observations, I also looked for elements that could be related in any way to those objectives and the research questions of my thesis.

According to Mulhall (2003), a researcher can use observation to gather insights into the interactions between dyads and groups. She mentions that, through observations, it is possible to illustrate the whole picture and capture the context of a phenomenon. Therefore, I used observation in my study, to enable me to gather data about the companies but also to observe the interactions between the parts involved and the environment that surrounds them. I also consider this data collection method to enable a better comprehension of the context of the observed phenomena.

\subsubsection{Documents studies}

Bryman and Bell (2011) state that, in case studies, documentation can be used as the basis for a description of a case company and its background. These authors suggest that documentation is likely to provide authentic and meaningful information about the companies. For this case study, we obtained full access to all the companies' existing documentation. We studied all of their existing internal documentation. This documentation involved their ways of working, organisational charts, flowcharts, procedures, environmental awareness and environmental efforts. We also analysed public documentation on environmental aspects of the companies, such as their environmental policy.

\subsubsection{Workshops}

The workshops were used to gather data from the companies. This is the data collection that I refer to as active, due to the involvement of the researchers in the object of study, the companies. The workshops were designed for each company separately during each phase. An additional workshop was designed for the two companies together, the joint workshop. The timeline for the workshops is shown in Table 6, Table 7 and Table 8. This outline for the workshops provided a way to gather and reveal information about each company. It also enabled the sharing of knowledge between the companies and a deeper understanding of process management and the uses it could have for companies in this sector.

The workshop planning was mainly undertaken by one of the researchers. I and the third researcher reviewed the contents of each workshop and collaborated with input and data when applicable before the development of the workshop. The workshops for each company, were divided into three main parts. In the first part, the researchers introduced the findings of the data collection. In this part, the researchers had an active role while the practitioners were mainly listeners. On the second part, the researchers designed, together with the practitioners the changes suggested for the company. In this second part, both researchers and practitioners had active roles. The third and last part was a discussion and reflection were both researchers and practitioners had active roles. After the workshops, each company would decide which changes, if any, they wanted to implement in their company. During these workshops I took an active listener role by asking questions when needed. I also answered to questions related to the data since I was the main responsible for the data collection.

The joint workshops were divided also in three parts. During the first part, each of the companies presented their status, which changes, if any, they had implemented and the way the implementation was done. They also presented results in cases where they applied, for example, the process maps developed in cooperation with the researchers. During the second part the companies interacted with each other, comparing their experiences and reflecting on the results. For these workshops we, the researchers took a more passive role in the 
development. The project manager was a mediator for the workshop. I was an active listener which reflected or discussed when needed.

The practitioners, representatives from the companies, participated together with the researchers to review the results of the data collection and the analysis conducted by the researchers. The practitioners, together with the researcher, would then analyse the findings, generating deeper knowledge and more applicable solutions for each company. During the development of the workshops, the researchers could also observe and analyse the effects of the suggested or implemented changes in the companies.

During the workshops, reflections were made upon the topics discussed, leading to reflective ideas and interactions between the companies. Additionally, at the end of each workshop, a reflection section was held, where all the people involved in the workshop could provide their points of view, including suggestions for improvement for future plans and workshops. Additionally, while running the workshops, we developed further observations and documentation, which worked not only to collect more data but also as a means to validate the findings.

During the meetings, seminars and workshops, notes were taken by the three researchers. The information in this documentation was validated during the respective or following meetings, seminars and workshops. I also used this documentation for the development of my thesis.

\subsection{The analysis}

For the analysis of the collected data and the results drawn from the literature reviews, I used a pattern-matching analysis (Yin, 2013). I identified similarities and contrasts in what process management methodology involves in the literature compared with the operations and management of the studied companies with a focus on how this methodology could enhance the environmental sustainability of companies within this sector. Additionally, I conducted an empirical analysis between the cases. In this empirical analysis, I developed a comparison between the two case companies to identify patterns that matched or differed between them. Later, I compared the findings to the existing literature in process management and green logistics in order to identify contrasts and similarities.

\subsection{Quality of the research}

As previously discussed in this chapter, this study is based on a qualitative approach. Therefore, I consider it important to rely on the four aspects of trustworthiness presented by Bryman and Bell (2011). These aspects are credibility, transferability, dependability and confirmability.

Credibility refers to how believable the research is (Bryman and Bell, 2011). For dealing with this aspect, I have used respondent validation and triangulation (Bryman and Bell, 2011). According to Bryman and Bell (2011), respondent validation is a process whereby the researcher presents his/her findings to the research subjects, i.e. the people on whom the research has been conducted. This process is a way to ensure a good correspondence between the findings made by the researcher and the perspectives and experiences of the research subjects. On the other hand, triangulation refers to the use of more than one data source and method for the research (Bryman and Bell, 2011).

In the case of Paper II, due to the division of the two disciplines, appointed thematic experts were present with me while conducting the interviews and observations. This allowed for peer examination of the findings as they emerged, which increased the credibility of the study (Meriam, 1988; Bryman and Bell, 2011). I documented each of the performed interviews by summarizing the interviews. The interview summaries were reviewed together with the respective 
thematic expert to ensure there were no misunderstandings or missing data in the documentation. Later, the documents were sent separately and exclusively to each interviewee. Each interviewee was asked to read the summary and suggest changes in cases where the data were misunderstood or to include clarifications, if needed. For the documents' studies, me and the thematic experts reviewed, separately, each of the available documents followed by a comparison of our findings. For triangulation purposes, all interviews, documents studies and observations were performed by a minimum of two researchers, in order to increase the reliability of the observational evidence (Meriam, 1988; Yin, 2013). Following each study visit, we presented a summary of the findings to each company, an agenda with the observed items, and a list of the interviews performed. The companies could then provide clarifications and validate the gathered data. Triangulation was also used to verify the mutual findings shared between the different data gathering methods.

Transferability refers to the ability to produce the same results of the research when applied in other contexts (Bryman and Bell, 2011). Bryman and Bell (2011) explain that this aspect is special for qualitative research, since the conditions of a case are, to an extent, unique, and it is difficult to transfer research results to other contexts were the same conditions apply. They mention that a way to ensure this aspect in research is to describe the research in great detail. For this reason, I have explained the methods used for my research and have also written the appended papers and the thesis in an extended way, explaining, in detail the results and conditions leading to the results. In addition, due to the use of an action research approach, transferability is limited since the researchers were active in developing the changes during the entire research process (Gummesson, 2000). Furthermore, even though generalisation of the results of this study may be limited and the study does not include a statistical analysis that can significantly prove the results, I anticipate that other SMEs may benefit from the findings and analysis in this thesis. My intention while writing this thesis was to provide a method and analysis for the reader with great detail to facilitate the adaptation of the study to other contexts and especially other SMEs within the road freight transport sector.

Dependability refers to the possibility for other researchers to produce the same results if they would reproduce the study (Bryman and Bell, 2011). The authors suggest that to ensure dependability, the research should be exposed to peers who act as auditors for the theoretical inferences. To ensure dependability, I have discussed my research and findings with thematic experts within the areas of quality management and logistics. Moreover, the documentation from the interviews and the notes from the study visits and workshops have been digitally stored as retrievable files. The interviews were performed using interview guides, included in Appendix I of this thesis.

Confirmability concerns the effect that researchers, by themselves, can have in affecting the interpretation of the findings (Bryman and Bell, 2011). Bryman and Bell (2011) explain that researchers should ensure that personal values or theoretical inclinations do not affect the research and its findings, in other words, that researchers should be objective. Guba and Lincoln (1994) state that ensuring objectivity in case studies is difficult due to the close interaction between the researcher and the object of the study. In my research, I have presented and discussed the results of my study with my supervisors. In addition, I have presented the research and findings in conferences and workshops to researchers from quality management and logistics. Furthermore, earlier versions of this thesis have been presented and discussed by researchers from both research areas. After each presentation I have reflected on the comments from other researchers and have added further explanations in the cases where needed.

When referring to the quality of my research, it is imperative to include the action research approach and the particular challenges connected in adopting this method. Rapoport (1970) 
recognises three challenges when using action research. One challenge is that the researcher should ensure confidentiality in relation to competitors and be impartial during the study while still reporting the research results to other researchers. This challenge is also addressed by Gummesson (2000). To achieve this confidentiality, the information of the interviewees was only available for me and the other two researchers. During the meetings and workshops, the results and analysis from the interviews were presented but there was no connection to the personal information of the interviewees. Furthermore, the anonymity of both companies involved in the study have been maintained in all research publications and external presentations, as well as that of the employees who contributed to the study. However, this confidentiality was not fully extended within the research project in the collaboration between the two case companies. The top management in each company agreed to participate in the research project and to interact with the other company. Additionally, to maintain objectivity, the funding of the project was provided by an external party.

The second challenge is that there might be a conflict of interests (Rapoport, 1970). On the one hand, researchers want to do good research but, on the other, they also want to generate practical solutions. The external funding for the main project of this thesis may have helped to avoid such a conflict of interest, as well as the presentations to other researchers from the quality management and logistics areas. For this second challenge, it is important to recognise the possibility of different stakeholder expectations, depending on whether they belong to the companies or academia. Gummesson (2000) presents some potential issues when conducting action research that directly relate to such possible differences in expectations. Documentation is the first of these. Gummesson (2000) argues that the researcher should ensure that the documentation of the study allows the reader to draw their own conclusions. The researcher's report is read by people who are usually not part of the research project and it is they who ultimately assess the credibility of the results (Gummesson, 2000). The documentation and credibility are usually of special interest to other researchers but may not be as interesting to the practitioners involved in the project. Practitioners may be more interested in the application of solutions and the results of such application. In this study, I have presented the results to several researchers in the areas of quality management and logistics. This, as mentioned above, was done to enhance the credibility of the research. The results were also presented to the companies involved in the study, in each phase of the project. During these presentations I gathered feedback regarding the generated practical solutions for each case.

The third challenge mentioned by Rapoport (1970) is the definition of the problem. He states that a possible issue with action research is that the researcher makes the final decision about how the problem is defined while it is the practitioners that have a major interest in stating and defining the problem. Based on the model presented by Ellström (2008), shown in Figure 13, I defined the problem for the research project in collaboration with the companies of the case study. In the introduction for this thesis, for the problematisation, I have thus also included practitioner perspectives when defining the problem. In doing so, I have tried to address the third challenge (Rapoport, 1970) by extending an understanding of problem using a broader view, beyond that of a researcher.

Gummesson (2000) presents validity as yet another challenge that differs from practitioners and academia. This challenge can be associated to the aspects of credibility and transferability presented by Bryman and Bell (2011). While the companies are interested in the validity of the results in their specific case, academia is interested in the general validity of the results (Gummesson, 2000). In order to increase the general validity of this thesis, I have used triangulation techniques (Meriam, 1988; Bryman and Bell, 2011), where other researchers have been involved in the analysis and confirmation of the results of my study and the validation of them. 


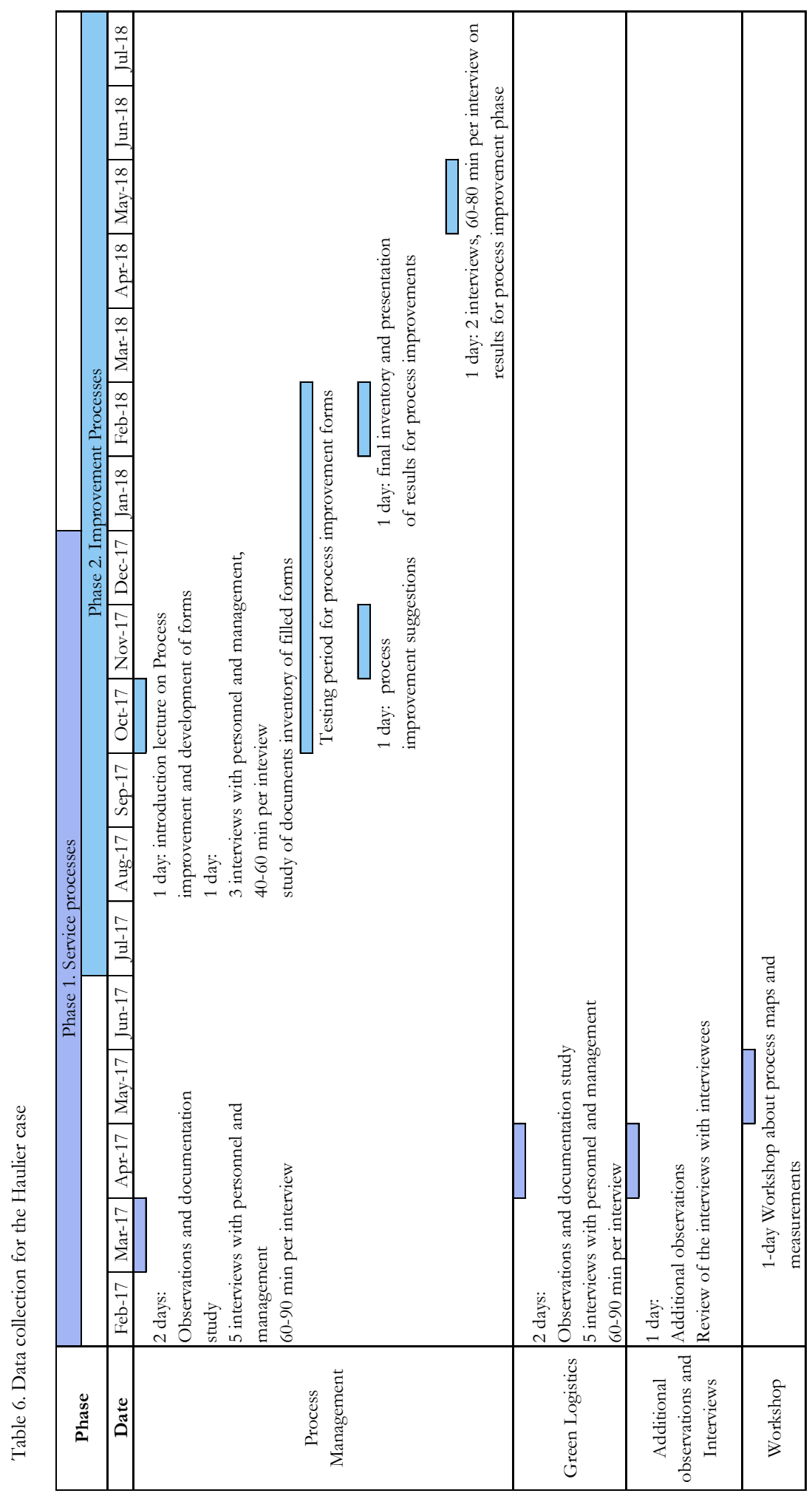




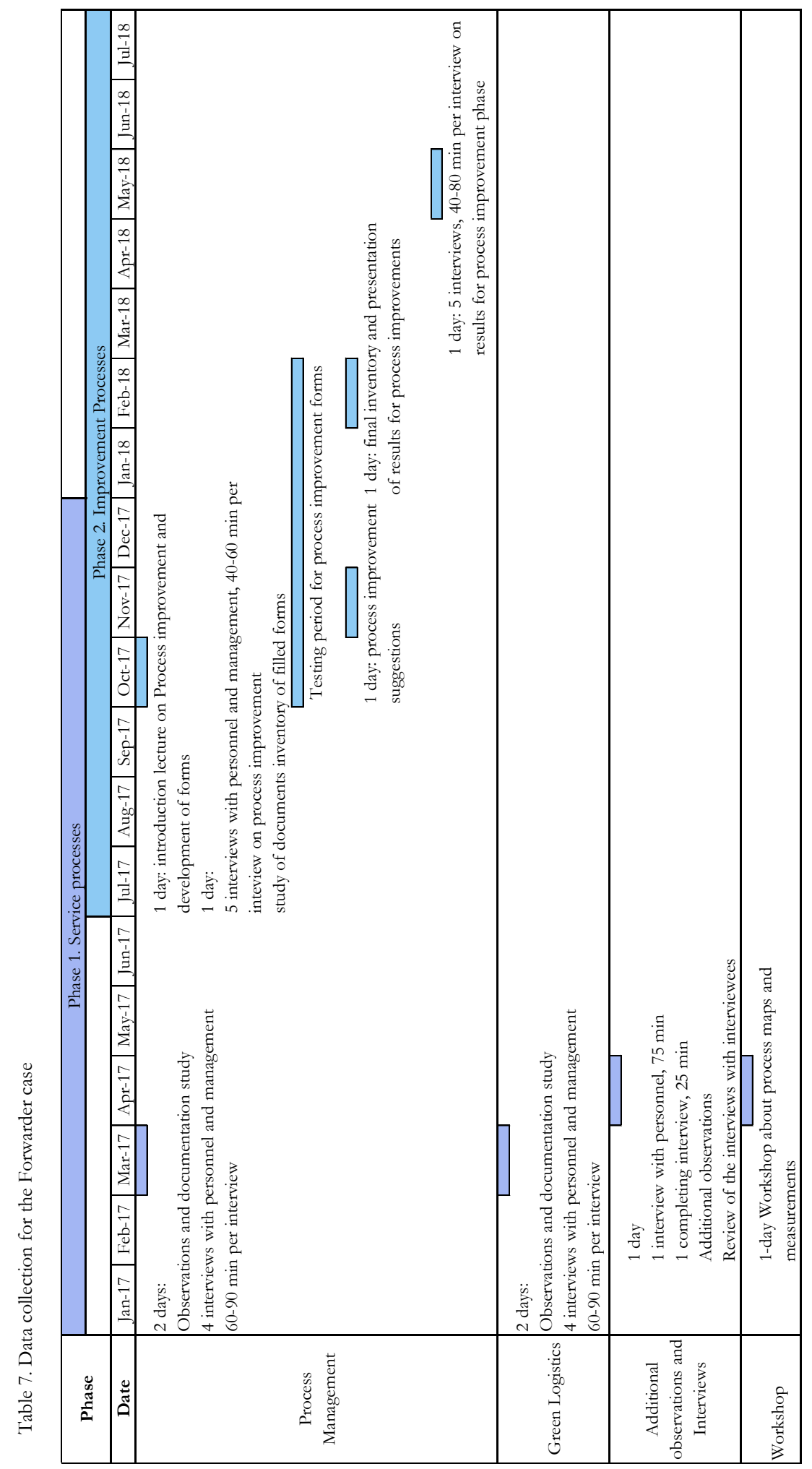




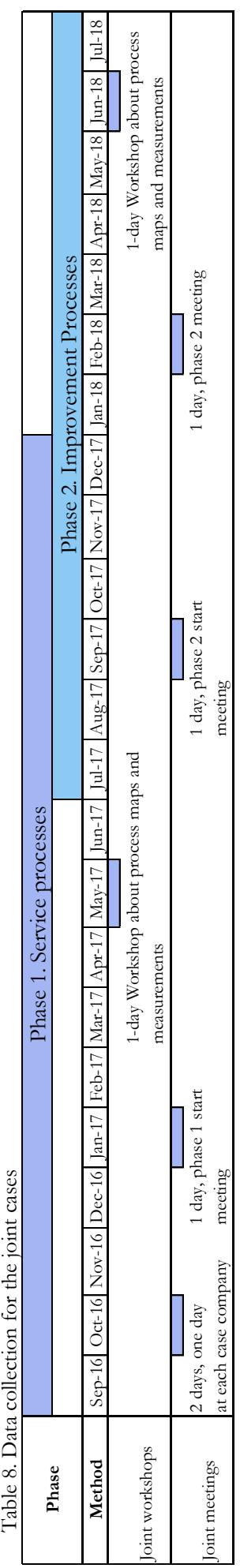




\section{SUMMARY OF THE APPENDED PAPERS}

In this chapter, I briefly present the appended papers, including the most relevant findings of my research. By means of these findings, I intend to answer the research questions in the following chapters. 


\subsection{Paper I}

\section{Applying quality methods for achieving environmental sustainability in the freight transport sector - reviewing process management and lean}

\subsubsection{Reference}

Navarro, P. and Cronemyr, P. (2018). Applying Quality Methods for Achieving Environmental Sustainability in the Freight Transport Sector: Reviewing Process Management and Lean. In Proceedings of $21^{\text {st }}$ QMOD-ICQSS Conference. Cardiff University, Wales.

\subsubsection{Purpose}

To revisit lean manufacturing and process management to review how they have targeted environmental sustainability, and to determine whether they have the potential to achieve environmental sustainability at companies in the freight transport sector.

\subsubsection{Research Questions}

RQ1: How has process management been used for achieving environmental sustainability? RQ2: How has lean manufacturing been used for achieving environmental sustainability? RQ3: Does process management have the potential for greening the freight transport sector? RQ4: Does lean manufacturing have the potential for greening the freight transport sector?

\subsubsection{Findings}

From the findings of Paper I, process management was used to provide the structure needed to measure the environmental impact of certain companies. A process view has also been used to support ISO 14000, which is an environmental management system. However, literature on the use of process management in the specific sector of freight transports was found to be limited.

It was also found that tools from lean, such as value stream mapping, have been used in some organisations to identify waste from an environmental point of view. In the freight transport business sector, similar approaches were used. The extent of the use of lean was considered to be broader than that of process management for achieving environmental sustainability.

The paper suggests that both process management and lean have the potential to support the achievement of environmental sustainability. However, they deal with the topic using different approaches. Lean takes an approach to targeting environmental sustainability with potential at an operative level, while process management has a higher potential at the strategic level. Both process management and lean require adaptations to be applied in order to support the greening of companies in the freight transport sector. They need to evolve from an economic and resources perspective to a broader one, which includes environmental sustainability as an objective. The freight transport sector could find benefit from both methodologies. However, while there do seem to be some researchers targeting transport with the use of lean to enhance environmental sustainability, process management has not been researched in depth. This business sector is currently facing tough goals on environmental impact. New techniques within logistics are emerging every day, such as improved vehicles with lower emissions, new management approaches that involve stronger coordination between the different stakeholders and new infrastructure from governments. All these new elements emerging from the business sector might find benefits in targeting environmental sustainability at a strategic level. Process management could provide the means for dealing with and fulfilling the new demands and opportunities that environmental sustainability represents.

\subsubsection{Theoretical contributions}

The paper provides a literature review on how both lean and process management can enhance environmental sustainability. It presents the latest research on this topic, which might provide an 
opportunity for other researchers to gain a better understanding of the state of this specific topic in academia.

\subsubsection{Managerial contributions}

Since this paper is theoretical, the managerial contribution is somewhat limited. Nonetheless, I consider the paper to be a guide for companies interested in applying lean or process management with the aim of improving their environmental performance which could aid them in choosing between these two methodologies.

\subsubsection{Contribution to the thesis}

The contribution of this paper to my thesis is to strengthen the argument for choosing process management as the focus of my study. Its main contribution, however, was to explore the principles and tools of process management and identify the ways in which other companies have implemented these elements of the methodology. This, together with the empirical data from the case study, was used to answer RQ1.

\subsubsection{My contribution}

My contribution to this paper is $90 \%$.

\subsection{Paper II \\ Greening logistics by introducing process management-a viable tool for freight transport companies going green}

\subsubsection{Reference}

Navarro, P.; Cronemyr, P. and Huge-Brodin, M. (2018). Greening logistics by introducing process management: A viable tool for freight transport companies going green. Supply Chain Forum: An International Journal. July 2018 Doi: 10.1080/16258312.2018.1486141

\subsubsection{Purpose}

To investigate how process management can enhance a customer-focused greening of the transport and logistics sector.

\subsubsection{Research Questions}

RQ1: How is the use of process management to enhance environmental sustainability in the freight transport industry described in current research?

RQ2: How is process management applied in environmentally ambitious freight transport companies?

RQ3: How can process management be introduced to enhance environmental sustainability in the freight transport business?

\subsubsection{Findings}

With this paper, we found that, in the literature, there is only limited and fragmented use of process management to enhance environmental sustainability in the freight transport sector. The limited results nevertheless indicate many positive relations between the pillars of process management methodology and the freight transport business sector, which suggests that there is potential for the methodology to be able to enhance environmental sustainability for companies in this business sector.

From an academic point of view, the paper revealed a large area with significant potential for research. For example, the methodology has potential to help in the greening of freight transport companies through the use of performance indicators to determine areas that require improvement and reductions in carbon emissions. 


\subsubsection{Theoretical contributions}

This paper constitutes an exploration of the literature written in the intersection of areas between the domains. The literature review includes a systematic and a narrative literature review which together provide other researchers with an overview of the literature on the topic studied in the paper. The paper also contributes to theory with the determination of a large area with significant potential for future research.

\subsubsection{Managerial contributions}

This paper includes a practical approach to including environmental aspects into process management methodology, specifically process maps. We also present a description of the workshops with thematic and practical experts as a way of introducing the methodology into freight transport companies.

\subsubsection{Contribution to the thesis}

This paper presents the data collected during the literature reviews for the exploration of the domains and intersections illustrated in Figure 2. Additionally, the empirical data included in the paper and the analysis performed made a great contribution to answering RQ1, RQ2 and RQ3.

\subsubsection{My contribution}

In this paper, my role is that of first author. I was responsible for the literature review. Additionally, with collaboration from the other two researchers, I designed the interview guides and performed the empirical data collection. I also contributed to the analysis process, which was performed jointly with the other two researchers. My contribution was $50 \%$ of the paper.

\subsection{Paper III}

\section{How to implement green logistics: using improvement processes for increasing environmental initiatives in freight transport companies}

\subsubsection{Reference}

Navarro, P.; Cronemyr, P.; Huge-Brodin, M. (2018). How to Implement Green Logistics - Using Improvement Processes for Increasing Environmental Initiatives in Freight Transport Companies. 21st International Conference in Excellence in Services. Paris, France.

\subsubsection{Purpose}

To explore the possibilities of using improvement systems, based on process management, to increase environmental initiatives in freight transport companies.

\subsubsection{Research Questions}

RQ1: How could improvement processes facilitate environmental initiatives in freight transport companies?

RQ2: What are the challenges of implementing improvement processes in freight transport companies?

RQ3: What are the potentials of implementing improvement processes in freight transport companies?

\subsubsection{Findings}

Paper III explored the possibilities of using improvement systems, based on process management methodology, to increase environmental initiatives in freight transport companies.

The paper suggests that environmental initiatives in freight transport companies could be facilitated with the use of process improvement by providing a more structured approach to managing and improving processes within the companies. Improvement processes can enable the 
environmental initiatives to be driven by both management and employees when embedded in the company's operations.

The paper considers the use of improvement processes to be a proactive approach to gathering improvement suggestions and customer feedback, targeting environmental issues in freight transport companies. Improvement suggestion and customer feedback forms could be the practical means for collecting this data. However, it is important for the forms to be simple to use and a process understanding on the part of employees is needed to increase the success of the use of improvement processes in the company. We also found a need for clear communication from management about the purpose and implementation of the improvement systems. This facilitates the use of the forms and the participation of both management and employees.

The paper also suggests that there are three challenges in the implementation of improvement processes. The first is that the lack of established processes can be an obstacle to the implementation of improvement processes. In the case studies at these companies, more established processes paved the way for a more successful improvement system. This confirmed, that Process Management 1-2-3 (Cronemyr and Danielsson, 2013) as a method was functioning as predicted, and in line with other contexts where it has been applied.

Another challenge to the implementation of improvement processes was found to be top management's engagement and commitment vs. the contributions from employees. Evangelista et al. (2017) state that environmental initiatives are often managed mainly by top management, and this was confirmed at these case companies. However, from our findings, we proved that the more established the processes, the more initiatives came from employees, and not only from top management.

The implementation of improvement processes was found to be considered as an attractive solution for the business per se. However, we found a fear among employees about following the formal demands and not being able to follow the instructions properly. This was the third challenge found in the paper. We suggest that the essence of this challenge is to identify a suitable level of formalisation that is well adapted to the particular case, while maintaining a dynamic attitude to the processes that is acceptable and realistic for the company.

\subsubsection{Theoretical contributions}

This paper provides confirmation of some of the models, especially maturity models, within process management methodology. It also provides evidence of the practical requirements for the implementation of improvement processes.

\subsubsection{Managerial contributions}

The paper can be considered as an introduction for management at freight transport companies that are interested in the implementation of the process management methodology, specifically for the phase of improvement processes.

\subsubsection{Contribution to the thesis}

The main contribution of this paper to the thesis was in answering RQ2 and RQ3. For RQ2 it provided data, both empirical and from the literature, and an analysis that allowed me to identify the challenges and benefits that freight transport companies may encounter when implementing process management to enhance environmental sustainability. With the challenges as a departure point, I was able to identify the changes needed for process management to be implemented in companies within the road freight transport sector.

\subsubsection{My contribution}

In this paper, I contributed to the data collection, the analysis and discussion sections. My contribution was $33 \%$ of the paper. 


\section{ANALYSIS AND DISCUSSION}

Throughout this chapter, I present the most relevant findings and, with help from the frame of reference, analyse their connection to providing an answer to the research questions and achieving the purpose of this thesis. First, I present the analysis for each case and, later on, the overall case study. 
To aid in visualising the connection between this analysis and discussion, and the conceptual model presented in Figure 3, an extended version was created and is presented in Figure 17. The discussion is based on this extended conceptual model.

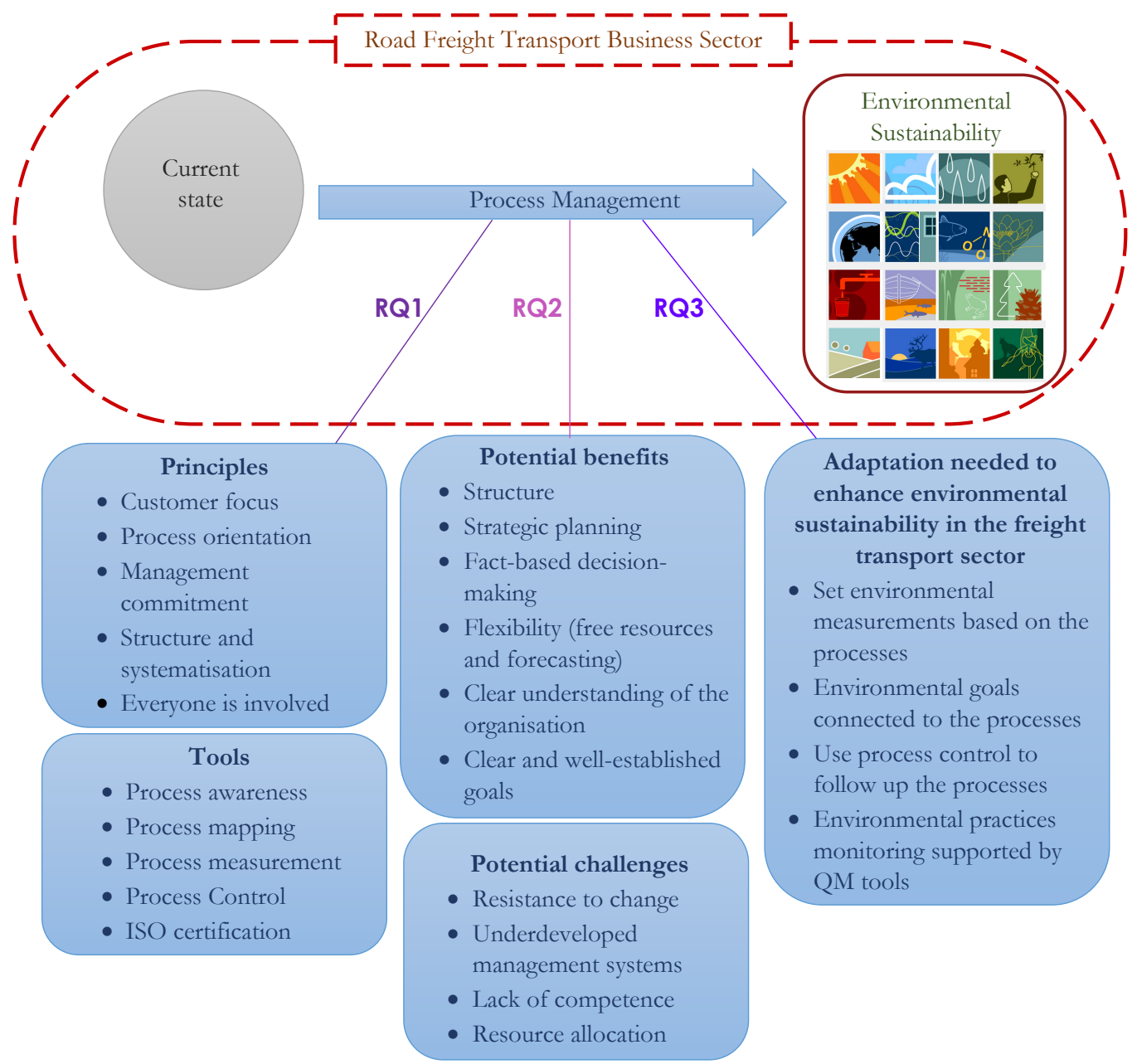

Figure 17. Developed conceptual model

The analysis is structured for each independent case according to the implementation steps of the process management maturity model. This is followed by an analysis of the interactions between the two cases. The final sections of this chapter present an analysis and discussion for each of the topics included in the research questions.

\subsection{Analysis and discussion of the findings at the Haulier case}

Prior to the implementation of process management, Haulier's top management had shown interest and made proactive efforts to enhance the company's environmental sustainability (Navarro et al., 2018a; Navarro et al., 2018b). Additionally, they had contacted an expert on process management, who had explained the basics of process management. Therefore, the $\mathrm{CEO}$ of the company was aware of the methodology but had no previous experience of 
working with it. In line with Kohlbacker and Gruenwald (2011), the CEO took a leadership role to advance the implementation. In contrast to these authors, the CEO did not have a deep understanding of the concept of the process approach.

Haulier has the reputation of being a high-quality transport company in the area in which it operates. The company's focus on customers' requirements, such as delivery time and accuracy in the delivery of goods, allows it to perform its services in a way that satisfies the customers. Furthermore, we found that management's interest in enhancing the company's environmental sustainability has moved them towards developing solutions with reduced environmental impact, such as aerodynamically modified vehicles (Navarro et al., 2018a). This demonstrates an interest in designing new solutions for the latent needs of both customers and society (SIQ, 2018). However, this customer focus connected to environmental aspects could only be identified in the company's management. Furthermore, the goals of the company involve economic results. These confirm two of the findings revealed by Evangelista et al. (2017). Firstly, environmental sustainability is not clearly stated in the company's strategy; and secondly, the environmental initiatives are mostly embraced by top management and there is no uniform awareness of this subject among the general workforce.

\subsubsection{The process awareness step at Haulier}

During the first step of the maturity model, process awareness, the management seminars provided a platform for discussing the administration of the company and its strategy in terms of environmental sustainability. The seminars also increased the process awareness and management commitment in terms of the implementation of process management. This was expected and is in line with Bergman and Klefsjö (2010) and Cronemyr and Danielsson (2013). As a new factor in the management seminars for the implementation of process management, the topic of environmental sustainability was included. These seminars proved to be a useful tool for introducing the subject to the key actors who attended the seminars and enabled the design of environmentally related goals. Additionally, we found they provided a space where understanding of the processes was enhanced with a more structured and systematic view of the company (Navarro et al., 2018a).

The management seminars for the process awareness step at Haulier involved the CEO and some administrative employees who were considered key actors for the implementation of process management. As a result, during these seminars, the different processes of the company were identified and process owners were appointed, including the employees involved in the management seminars. The discussions mentioned above are in line with the activities belonging to the process design task group presented by Paim et al. (2008). As they explain, understanding the internal and external environments and setting strategies, goals and approaches is critical for the implementation of process management. In this company, it allowed the identification of the different processes necessary to satisfy customers' needs.

\subsubsection{The process development step at Haulier}

The group involved in the management seminars continued to be a key actor during the process development step. In this step, the process teams and owners were appointed, and preliminary process maps were designed in cooperation with us, the researchers (Navarro et al., 2018a). These maps were developed based on our interviews with the employees, which is in line with the approach suggested by Rohloff (2011). Involving these employees, whom management considered to be key actors, gave them a sense of belonging and ownership of the implementation of process management. For the preliminary process maps, environmental goals were selected, connected to the strategy determined during the process awareness step. There was management commitment to the implementation of the methodology, but there was no clear designation of time and human resources for the establishment of the processes nor a clear timeframe for the implementation. These ambiguities represent an inhibitor for 
the implementation of process management because employees become immersed in their everyday activities and process development is not prioritised.

The outcome of the process development step was not in line with the outcomes of this step in the literature (Paim et al., 2008; Bergman and Klefsjö, 2010; Cronemyr and Danielsson, 2013). The process owners and teams did not have meetings or workshops and the preliminary process maps were not developed further. Process mapping is a tool that, when applied correctly, can facilitate both internal and external communication (Paim et al. 2008). This facilitation of communication was still achieved to an extent by the preliminary process maps. Internally, for the employees involved in the seminars, this tool provided a visualisation of the tasks and activities performed by the company to achieve customer satisfaction and connection. However, I consider that this visualisation and internal awareness of the processes based on the preliminary process maps was ephemeral because the employees did not use the process maps outside of their project-related activities. Externally, the process maps were used for marketing as a visualisation of the processes in the company. Haulier's management system is not certified, and the preliminary process maps provided the means to illustrate a structure for the company that could fulfil customers' requirements and interest potential customers. This is in line with Paim et al. (2008), who state that process maps can create trust in the company from external parties. Additionally, the inclusion of environmental goals on the process maps provided a means for visualising the company's interest in improving its environmental sustainability. From an internal point of view, the inclusion of these environmental goals increased the awareness of environmental aspects among the employees who were involved in the seminars. However, since the process maps were neither launched nor communicated to the rest of the employees, process awareness was not possible for them.

In the Haulier case, there was a limited but pre-existing process orientation at the beginning of the study. This process view and orientation is in line with Mangan and Christoffer (2005). Employees were each responsible for the activities concerning their specific functional areas in the company, but they would work together to find solutions if there were customer complaints. The process orientation principle of process management was enhanced to a certain extent when introducing the methodology to the company. Process maps allow a visualisation of the different processes, their placement within the main process and their connections with other processes. This makes the process structure visible to employees, who were previously only aware of the functional structure. Nonetheless, for Haulier, this applied only to employees with knowledge of the implementation of process management. I conclude that Haulier acquired a process view but did not reach higher levels of process orientation (e.g. Hellsten and Klefsjö, 2000; Hellström and Eriksson, 2008). For the employees involved in the management seminars, there was a process awareness to the extent that they could visualise the barriers to the processes and the connections between processes. They could also see the placement of each process within the main process of the company.

\subsubsection{The process improvement step at Haulier}

We developed a form to collect suggestions for improvements from the employees of Haulier, which the company later applied (Navarro et al., 2018b). However, the efforts within the process improvement step were inhibited by the outcomes of the process development. Processes should be communicated to all employees and the process view should be used across the entire company if process management is to be successful (e.g. Paim et al., 2008; Palmberg, 2009; Bergman and Klefsjö, 2010; Rohloff, 2011; Cronemyr and Danielsson, 2013; SIQ, 2018). The underdevelopment of the process maps and the involvement of just some of the employees were barriers to the process improvement efforts (Navarro et al., 2018c). We determined that it was not possible to establish a connection between the suggestions for improvement that were received and environmental sustainability (Navarro et al., 2018b). Haulier employees believed that there was a prioritisation of time and quality results, and they 
did not consider environmental sustainability or the targets associated with the processes due to that prioritisation. Seuring and Wolf (2010) argue that customers tend to prioritise operational and financial results over environmentally friendly ones. This prioritisation coincides with the priorities that the employees have for their tasks.

The results of the implementation of process management at Haulier confirmed the conclusions of Cronemyr and Danielsson (2013) and Rohloff (2011). They concluded that process management should be implemented in a stepwise manner in order to be successful. Haulier directed efforts towards underdeveloped processes, leading to an unsuccessful implementation of the process management methodology. However, the implementation of the principles of process management, such as management commitment, systematisation, process orientation and customer focus, had the potential to support environmental practices and initiatives. Nevertheless, I consider that environmental and process awareness should be present across the entire company for those principles to become a support for its operations and the enhancement of its environmental sustainability. Likewise, tools such as process mapping, management seminars and workshops functioned to increase both process awareness and environmental awareness. However, this improvement was only temporary. Therefore, I consider that these tools require strong management commitment, including a continuous following of the development, in order to provide benefits to companies and support the enhancement of environmental sustainability.

The findings from Haulier are summarised in Table 9, Table 10 and Table 11.

Table 9. Principles found at Haulier

\begin{tabular}{|c|c|c|}
\hline Principles & Before process management & After process management \\
\hline Customer focus & $\begin{array}{l}\text {-Focus on delivery time and accuracy } \\
\text {-Top management interested in } \\
\text { environmental thinking }\end{array}$ & $\begin{array}{l}\text { Focus on delivery time, accuracy and } \\
\text { environmental impact. }\end{array}$ \\
\hline Process orientation & $\begin{array}{l}\text { No process awareness and limited } \\
\text { process orientation }\end{array}$ & $\begin{array}{l}\text {-Process awareness } \\
\text {-Identification of processes } \\
\text {-Process owners and teams assigned } \\
\text {-Preliminary processes designed but } \\
\text { not used }\end{array}$ \\
\hline Management commitment & $\begin{array}{l}\text { Management was committed to high } \\
\text { quality and was environmentally } \\
\text { ambitious } \\
\text { No deep understanding of the } \\
\text { process approach }\end{array}$ & $\begin{array}{l}\text { Management has process awareness } \\
\text { and is committed to the } \\
\text { implementation of process } \\
\text { management but no clear goals or } \\
\text { guidelines have been given to } \\
\text { employees }\end{array}$ \\
\hline Structure and systematisation & $\begin{array}{l}\text {-Functional structure } \\
\text {-No processes documented nor used }\end{array}$ & $\begin{array}{l}\text {-More horizontal structure } \\
\text {-Preliminary processes documented }\end{array}$ \\
\hline Everyone involved & $\begin{array}{l}\text {-Each employee is only responsible } \\
\text { for their own tasks }\end{array}$ & $\begin{array}{l}\text {-Each employee is responsible for } \\
\text { their own process, but the employees } \\
\text { involved in the process management } \\
\text { implementation are aware of other } \\
\text { processes in the company and how } \\
\text { they intereact with each other } \\
\text {-Environmental thinking present on } \\
\text { the employees involved in the } \\
\text { process management implementation }\end{array}$ \\
\hline
\end{tabular}


Table 10. Tools applied at Haulier and results

\begin{tabular}{|c|c|c|}
\hline $\begin{array}{l}\text { Process management } \\
\text { implementation step }\end{array}$ & Tool & Results \\
\hline \multirow[t]{2}{*}{ Process awareness } & Management seminars & $\begin{array}{l}\text {-Platform for strategic discussions and } \\
\text { reflections for environmental } \\
\text { sustainability } \\
\text {-Increased process awareness } \\
\text {-Increased management commitment } \\
\text { - Environmental awareness } \\
\text {-Processes identified } \\
\text {-Process owners and teams designated }\end{array}$ \\
\hline & Management workshops & $\begin{array}{l}\text {-Deeper understanding of the processes } \\
\text {-Sense of belonging for the employees } \\
\text { involved }\end{array}$ \\
\hline Process development & Process mapping & $\begin{array}{l}\text {-Deeper understanding of the processes } \\
\text {-Clearer structure } \\
\text {-Clearer interaction between processes } \\
\text {-Visualisation of the structure and } \\
\text { interactions } \\
\text {-Process maps were useful for marketing } \\
\text { purposes } \\
\text {-Environmental goals linked to activities } \\
\text { and processes } \\
\text {-Facilitated communication for internal } \\
\text { and external parties }\end{array}$ \\
\hline Process improvement & $\begin{array}{l}\text {-Employee improvement } \\
\text { suggestions } \\
\text {-Customer feedback }\end{array}$ & $\begin{array}{l}\text {-No benefits registered } \\
\text {-Low involvement from management, } \\
\text { unclear instructions } \\
\text {-Customers not informed } \\
\text {-Administrative employees not involved }\end{array}$ \\
\hline
\end{tabular}

Table 11. Challenges faced by Haulier

\begin{tabular}{|c|c|}
\hline Challenges & Explanation \\
\hline $\begin{array}{l}\text {-Environmental awareness present only in top } \\
\text { management }\end{array}$ & $\begin{array}{l}\text { Top management is interested in enhancing } \\
\text { environmental sustainability but does not state } \\
\text { explicit guidelines or goals }\end{array}$ \\
\hline $\begin{array}{l}\text {-Lack of management and employees } \\
\text { competences }\end{array}$ & $\begin{array}{l}\text { Employees and management have no training nor } \\
\text { previous experiences in process management }\end{array}$ \\
\hline -Underdeveloped management systems & $\begin{array}{l}\text { Processes not established before the process } \\
\text { improvement step is implemented }\end{array}$ \\
\hline -Resistance to change & $\begin{array}{l}\text { Employees and management have no training or } \\
\text { previous experience in process management }\end{array}$ \\
\hline -Resource allocation & $\begin{array}{l}\text { No time or personnel assigned for the process } \\
\text { management implementation }\end{array}$ \\
\hline
\end{tabular}




\subsection{Analysis and discussion of the findings at the Forwarder case}

Forwarder, as explained in Chapter 3, is a cooperative of hauliers. This means that the company focuses on the coordination and management of a group of hauliers and their operations. The CEO of the company had previous experience in organisations that used process management. Consequently, he was aware of the methodology and its potential benefits. Additionally, the quality manager, who was involved in the implementation from the start, is interested in implementing a more horizontal structure within the company. Both $\mathrm{CEO}$ and quality manager shared responsibility for the advancement of process management and had a deep understanding of the concept of the process approach (Kohlbacher and Gruenwald, 2011).

\subsubsection{The process awareness step at Forwarder}

The management at Forwarder had previously identified the business's need for this horizontal structure and to enhance its environmental sustainability. They had previously implemented some environmental practices to enhance the company's environmental sustainability (Navarro et al., 2018a). As at Haulier, these practices confirm an interest in designing new solutions to the latent needs of both customers and society (SIQ, 2018). The identification of a need and the interest of top management as a first step in the implementation of process management are mentioned by Cronemyr and Danielsson (2013).

Forwarder is customer focused; the company maintains constant contact with its customers and monitors certain performance indicators that are of interest to its customers. The sales department usually makes the first contact with customers, when the customer's requirements are determined, and the conditions of service are established. Then the transport agents usually take over communication with both the customers and the hauliers. Among the performance indicators that Forwarder monitors are the accuracy of the delivery and on-time deliveries. They undertake this monitoring daily, supported by an IT system that registers the transports and provides statistical diagrams of the data, as well as the statistics for each day. This information is available to all the company's employees and the hauliers. The monitoring of performance, together with the regular customer contact, allows Forwarder to determine and monitor the fulfilment of customers' requirements. This is in line with Näslund (2002), since the creation of processes enables the establishment of units for which the measurement can be taken to monitor the efficiency and effectiveness of Forwarder.

The management system at Forwarder was more sophisticated than that of Haulier. The company had established process flow maps, IT systems, routines, manuals and documentation for its operations and management. This can be explained by the difference in size of the companies and the fact that Forwarder is ISO certified. The ISO certification provided them with a greater process orientation (e.g. Poksinska et al., 2003; Hellström and Eriksson, 2008; Kohlbacher and Gruenwald, 2011; Navarro and Cronemyr, 2018). The management system at Forwarder included basic process maps, which confirmed the process view level (Hellström and Eriksson, 2008).

During the process awareness step of the implementation Forwarder, like Haulier, developed introductory management seminars. During these seminars, the different processes within the company were identified, and preliminary process maps were developed based on the existing process maps and interviews (e.g. Rohloff, 2011). Additionally, preliminary environmental goals were set on the processes of the company as an example of potentials goals per process. One example of the goals established for the core processes was connected to the direct environmental effect of the fuels used in the company.

\subsubsection{The process development step at Forwarder}

During this step, process owners and teams were assigned to each process. In contrast to Haulier, management assigned responsibility for the development of the processes to each process 
owner. Forwarder's management also developed process owners' meetings, at which an introductory seminar about process management methodology was given by an expert on the subject. This seminar provided the process owners with a greater understanding of process management methodology and process mapping tools. Additionally, an expert on green logistics presented environmental practices for road freight transport companies and explained how they could be associated with the different processes.

Furthermore, process owners and teams had separate meetings to discuss and develop the process maps. The ambition of management was to establish and launch the new and improved process maps before the next audit for the ISO 9000 certification. This provided a timeframe for the development phase. Forwarder thus had clearer instructions and explicit goals for the process owners and their teams. The management seminars, process team meetings and workshops provided a platform for the implementation of process management. The introductory seminar addressed the lack of knowledge, and the assigning of process owners gave a sense of belonging and ownership to the employees involved (e.g. Paim et al., 2008; Bergman and Klefsjö, 2010; Cronemyr and Danielsson, 2013). The workshops specifically enabled reflections by management on the need to apply requirements for employees in order to enhance environmental sustainability (Navarro et al., 2018a). As a result, from these reflections, new policies were developed to decrease the company's environmental impact. As in the Haulier case, the management seminars and workshops enabled a more systematic view of the company and the connections between the processes through the development of the process maps (Navarro et al., 2018a). Additionally, the process development for each of the processes allowed a deeper understanding of both the processes and the involvement of other employees (Paim et al., 2008).

This company has a clear environmental policy which is available to all employees and customers. Furthermore, the environmental management system of the company is certified by ISO 14000. This proves the affirmation by Cassells, Lewis and Findlater (2012) to be wrong. While the authors state that process management is a key factor for the implementation of ISO 14000 , Forwarder proves that it is possible to achieve the certification without employing the methodology. Nonetheless, a process orientation was present in the company. During the development of the preliminary process maps, potential process indicators were designed for some of the processes, which were in line with the company's environmental policy. However, management was not as clear about the importance of these aspects when communicating tasks to the process owners. As with Haulier, this confirms that the responsibility for environmental sustainability usually remains with top management (Evangelista et al., 2017). Some of the environmental performance indicators set at Forwarder were percentage of vehicles allowed in environmental zones and percentage of vehicles which are at least classified as Euro5. These two indicators were connected to the goal for usage of environmentally friendly fuels.

For Forwarder, most of the outcomes of the process development step were in line with the literature on process management maturity (Paim et al., 2008; Bergman and Klefsjö, 2010; Cronemyr and Danielsson, 2013). However, the processes had not been launched and were not entirely established due to time constraints, the prioritising of everyday tasks and time pressure. Consequently, the processes were used but not the process maps. Therefore, it was not possible during the study to determine whether the process maps had any effect on internal communication within the company. However, externally, the company received positive feedback on the changes during an ISO 9000 audit. Furthermore, the addition of environmental aspects to the process maps allowed the visualisation, both internally and externally, of potential measurements for the company's environmental performance. As a confirmation of Cosimato and Troisi (2015), the use of ISO 9000 and ISO 14000 supports green initiatives and increases competitiveness. During the use of ISO 9000, process orientation and the process maps enabled the establishment of explicit goals and measurements for the different processes, while ISO 14000 allowed the incorporation of an environmental policy and environmental practices by Forwarder. 


\subsubsection{The process improvement step at Forwarder}

During the improvement step in the implementation of process management, Forwarder obtained improvement suggestions from employees connected to the processes. As found by Navarro et al. (2018b), employees did not associate the improvements with environmental aspects. Nonetheless, the researchers found that their suggestions were indirectly connected to enhancing environmental sustainability. This confirms the affirmation by Azevedo et al. (2012) that quality management methodologies, in this case process management, enable programmes for environmental sustainability. Moreover, in line with Garvare and Isaksson (2001) and Isaksson and Garvare (2003), process management provides a systemic overview of environmental sustainability and allows the measurement of environmental aspects. Similar to Ghose et al. (2009), process orientation enabled these measurements to be assigned to specific activities within the processes (Navarro et al., 2018a). Moreover, the improvement step was strengthened by the principle of management commitment. The CEO and the quality manager motivated and reminded employees of the possibility of making suggestions for improvements and actively participated in collecting these suggestions. Like the Haulier employees, Forwarder employees mentioned time constraints and the prioritisation of other activities, which they believed resulted in few suggestions for improvement. However, the management commitment within this company enabled more employees to participate in the improvement suggestions. This is in line with Deming (1986), Flynn et al. (1995) and Krajcsák (2019). Nonetheless, there was resistance to change identified among some employees, including members of the management team. They stated that their ad-hoc approach to solving problems allowed them to react rapidly when facing issues. However, this reactive way of solving issues, together with a lack of documentation and facts upon which to base decision-making, resulted in recurring issues and solutions applying only to the symptoms of a problem, instead of its root cause (Doggett, 2005).

The implementation of process management at Forwarder was more in line with the stepwise maturity model than at Haulier. After the improvement phase from the study, Forwarder had reached a process mapping level and had ambitions towards achieving the process management level. This, according to Cronemyr and Danielsson (2013) and Rohloff (2011), could explain the difference in the degree of success between the companies. A summary of the findings at Forwarder is presented in Table 12, Table 13 and Table 14.

\subsection{Interaction of the cases}

The joint workshops for each of the implementation steps of process management methodology proved to be a good tool for the sharing of knowledge (Navarro et al., 2018a; Navarro et al., 2018b). The workshops enabled reflections on the implementation of the methodology in each company and provided the means for developing mutual knowledge (Navarro et al., 2018a). The interactions between the management of Haulier and Forwarder allowed reflections on the managerial styles used for the implementation. Forwarder used a more authoritarian and clear delimitation of the results expected of their employees, while the management at Haulier did not establish either guidelines or targets.

During the process development workshops, both management groups expressed interest in implementing the methodology with a connection to environmental aspects and measurements. After the process improvement workshops, that interest was still present. However, there was a different degree of management commitment between the companies. At Haulier, management commitment was limited to participation in the study while, at Forwarder, management commitment included a closer proximity to the implementation of the process management methodology. This closer proximity included setting targets, drawing up policies and offering introductory seminars on process management and environmental sustainability. 
The workshops provided a moment for reflection on the work that had been undertaken for the implementation of process management for each of the companies. It also enabled a space for comparison of the results obtained, based on the decisions made about the implementation.

Table 12. Principles found at Forwarder

\begin{tabular}{|c|c|c|}
\hline Principles & Before process management & After process management \\
\hline Customer focus & $\begin{array}{l}\text { Focus on delivery time and accuracy, } \\
\text { innovation and environmental } \\
\text { thinking for the entire company }\end{array}$ & $\begin{array}{l}\text { Focus on delivery time and accuracy, } \\
\text { innovation and environmental } \\
\text { thinking. Environmental information } \\
\text { about services is given to the } \\
\text { customers. }\end{array}$ \\
\hline Process orientation & $\begin{array}{l}\text {-Documented basic process maps } \\
\text {-ISO } 9000 \text { and ISO } 14000 \text { certified }\end{array}$ & $\begin{array}{l}\text {-Designated process owners and } \\
\text { teams } \\
\text {-Processes established }\end{array}$ \\
\hline Management commitment & $\begin{array}{l}\text {-Strong management committment } \\
\text { and involvement } \\
\text {-Management interested in } \\
\text { improvements } \\
\text {-Management was committed to high } \\
\text { quality and was environmentally } \\
\text { ambitious }\end{array}$ & $\begin{array}{l}\text {-Management has deep } \\
\text { understanding of the process } \\
\text { approach } \\
\text {-Management is committed to the } \\
\text { implementation of process } \\
\text { management and explicit goals and } \\
\text { guidelines have been given to the } \\
\text { employees } \\
\text {-Process management work and } \\
\text { implementation communicated to all } \\
\text { administrative employees }\end{array}$ \\
\hline Structure and systematisation & \begin{tabular}{|l|}
-Functional structure \\
-Processes documented but not used
\end{tabular} & $\begin{array}{l}\text {-More horizontal structure, teams } \\
\text { and process owners responsible for } \\
\text { the maintenance of each process } \\
\text {-Processes documented and partially } \\
\text { used }\end{array}$ \\
\hline Everyone involved & $\begin{array}{l}\text {-Each employee is only responsible } \\
\text { for their own tasks }\end{array}$ & $\begin{array}{l}\text {-Each employee is part of one or } \\
\text { more process teams } \\
\text {-Most of the employees involved in } \\
\text { the process management } \\
\text { implementation are aware of other } \\
\text { processes in the company and how } \\
\text { they intereact with each other } \\
\text {-Sense of belonging and ownership } \\
\text { of the processes } \\
\text {-Environmental thinking from all } \\
\text { employees but not environmental } \\
\text { awareness }\end{array}$ \\
\hline
\end{tabular}


Table 13. Tools applied at Forwarder and results

\begin{tabular}{|c|c|c|}
\hline $\begin{array}{l}\text { Process management } \\
\text { implementation step }\end{array}$ & Tool & Results \\
\hline \multirow{4}{*}{ Process awareness } & Management seminars & $\begin{array}{l}\text {-Platform for strategic discussions and } \\
\text { reflections for environmental sustainability } \\
\text {-Increased process awareness } \\
\text {-Increased management commitment } \\
\text {-Environmental performance indicators } \\
\text { designed for each process } \\
\text {-Environmental awareness (B) } \\
\text {-Processes identified } \\
\text {-Process owners and teams designated }\end{array}$ \\
\hline & Management workshops & $\begin{array}{l}\text {-Deeper understanding of the processes (B) } \\
\text {-Sense of belonging among the involved } \\
\text { employees involved } \\
\text {-Design of requirements for environmental } \\
\text { aspects }\end{array}$ \\
\hline & $\begin{array}{l}\text { Introductory seminar to } \\
\text { process management }\end{array}$ & $\begin{array}{l}\text {-Increased knowledge and understanding of } \\
\text { process management }\end{array}$ \\
\hline & ISO certification & $\begin{array}{l}\text {-ISO } 9000 \text { provided a higher process } \\
\text { orientation and ISO } 14000 \text { established } \\
\text { environmental policies (B) }\end{array}$ \\
\hline Process development & Process mapping & $\begin{array}{l}\text {-Deeper understanding of the processes (B) } \\
\text {-Clearer structure (B) } \\
\text {-Clearer interaction between processes (B) } \\
\text {-Visualisation of the structure and } \\
\text { interactions (B) } \\
\text {-Process maps were useful for marketing } \\
\text { purposes (B) } \\
\text {-Environmental measurements linked to } \\
\text { activities and processes (B) } \\
\text {-Facilitated communication for internal and } \\
\text { external parties (B) } \\
\text {-Higher involvement from employees (B) } \\
\text {-Process maps not used } \\
\text {-Process maps not completely developed } \\
\text { due to resource constraints }\end{array}$ \\
\hline Process improvement & $\begin{array}{l}\text {-Employee improvement } \\
\text { suggestions } \\
\text {-Customer feedback }\end{array}$ & $\begin{array}{l}\text {-High involvement from management, clear } \\
\text { instructions } \\
\text {-Customer feedback actively collected } \\
\text {-Administrative employees informed } \\
\text {-Environmental aspects embedded in } \\
\text { improvement suggestions and feedback (B) }\end{array}$ \\
\hline
\end{tabular}


Table 14. Challenges faced by Forwarder

\begin{tabular}{|l|l|}
\hline \multicolumn{1}{|c|}{ Challenges } & \multicolumn{1}{c|}{ Explanation } \\
\hline -Processes maps not used & $\begin{array}{l}\text { The processes were used but not the process } \\
\text { maps. }\end{array}$ \\
\hline $\begin{array}{l}\text {-Lack of management and employees } \\
\text { competences }\end{array}$ & $\begin{array}{l}\text { Employees and management have no training } \\
\text { nor previous experience in process } \\
\text { management }\end{array}$ \\
\hline -Resistance to change & $\begin{array}{l}\text { Some employeesprefer the ad-hoc approach to } \\
\text { solving problems and consider that process } \\
\text { management requires documentation and time }\end{array}$ \\
\hline -Resource allocation & $\begin{array}{l}\text { Limited time and personel assigned for the } \\
\text { process management implementation }\end{array}$ \\
\hline
\end{tabular}

\subsection{Principles of process management for freight transport companies}

Process orientation is relevant when using process management to enhance environmental sustainability in freight transport companies. The principle of process orientation means that an organisation adopts a process view (Hellström and Eriksson, 2008; Bergman and Klefsjö, 2010; Kohlbacher and Gruenwald, 2011). This was confirmed in the case study, especially in the Forwarder case. The companies obtained a clearer view of their operations once process management was introduced. Process orientation promoted stronger integration by delimitating the different activities within the companies using processes and determining the appropriate outputs for each process. There was stronger coordination when the processes were viewed as a sequence and when the companies had determined how each process was positioned within its main process and how it was connected to the rest of the processes. I also found a more systemic view of the organisations; both employees and management started seeing the companies as a whole, instead of referring to their functional structures. The Forwarder case confirmed that process orientation can be enhanced by the use of ISO 9000 (e.g. Poksinska et al., 2003), while both cases confirmed that it can be enhanced by the use of process management (Navarro and Cronemyr, 2018a).

Another principle of relevance to freight transport companies interested in implementing process management to enhance environmental sustainability is customer focus. Process management bases the development of processes on customers' requirements and the activities needed to satisfy those customers. Consequently, the measurements and goals for these processes are closely connected to customer satisfaction. Customer satisfaction should be achieved by taking into consideration both current and latent customer needs. The wider society should also be considered when determining a customer's needs, because it can influence their latent needs. Today's customers do not always require freight transport companies to offer services that are more environmentally sustainable, but this is a latent need. It has been proven that environmental aspects have become societal needs and that companies should strive to identify and fulfil these needs (SIQ, 2018). Therefore, companies need to make efforts to improve their operations from an environmental point of view. Including the principle of customer focus when using process management in these companies would then imply the consideration of environmental aspects and the requirements of both external customers and society. Hence, this principle enables the enhancement of environmental sustainability in freight transport companies. In the case study, it was confirmed that environmental sustainability is still not a "must have" requirement for customers. Nonetheless, it is a "more is better" or "delighter" for some (Kano, 2001).

A third principle that I consider relevant to enhancing sustainability in the freight transport sector is management commitment. Process management requires a strong management 
commitment to ensure the success of its implementation (Cronemyr, 2007; Cronemyr and Danielsson, 2013). This does not change when incorporating the environmental element into the equation, which was proven in the case study.

The freight transport sector is a fast-moving sector involving highly competitive pressures (Evangelista and Sweeney, 2014). New techniques and technologies that the freight transport sector can use are continually emerging. These new elements that the business sector needs to consider might mean that there are benefits in targeting environmental sustainability, both as a customer requirement and at a strategic level. Therefore, the principle of customer focus within process management resonates with dealing with and fulfilling the new demands and opportunities that environmental sustainability represents.

Another principle from process management methodology that could support the enhancement of environmental sustainability in this business sector is the structure and systematisation that is involved when implementing the methodology (e.g. Lee and Dale, 1998; Biazzo and Bernardi, 2003; Palmberg, 2009). In the case study, it was confirmed that this methodology can provide a systemic view of the environmental aspects of sustainable development (Garvare and Isaksson, 201; Isaksson and Garvare, 2003). Process management involves all parts of an organisation and everyone in it, even external parties such as suppliers and customers. This holistic view of an organisation allows better coordination and a clearer structure, enabling both internal and external communication. Process management also allows organisations to develop a more horizontal structure, focusing on the activities that add value for the customer. Most organisations have a clear vertical structure, meaning that they are structured in a functional way. Process management provides them with a structure based on the activities that are supported by the functional structure (Benner and Tushman, 2003; Hellström, 2008; Paim et al., 2008). This allows organisations to strive for customer focus while retaining entities responsible for resource allocation and development, the functional structures.

The final, but by no means least, principle is the involvement of all the parties involved. I previously mentioned that, in process management, it is not only all the employees and management who are involved, but even suppliers and customers. This principle allows for the design, establishment, monitoring, control and improvement of the processes, involving all parties who might be affected by or affect the outcome of the process. The involvement of everybody allows a better design, easier monitoring and greater improvement for each of the processes of an organisation (Paim et al., 2008; Cronemyr and Danielsson, 2013). From an environmental perspective, the involvement of all parties may allow a greater awareness of environmental sustainability and more suggestions for improvements connected to environmental sustainability (Navarro et al., 2018).

\subsection{Potential tools of process management for freight transport companies}

The process management methodology makes use of different tools. I found the following to be the most useful for enhancing the environmental sustainability of freight transport companies. Process mapping is the first tool; it provides an overall picture of the processes required to satisfy a company's customers. In the case companies, it proved to enable a better understanding of each company's purpose. Additionally, these seminars proved to be a useful tool for management to reflect upon their operations, their results and the range of services they offer to customers from an environmental perspective. These reflections resulted in clearer paths for the companies' environmental development, clearer goals for their operations and environmental effects, and new services with reduced environmental impact being offered to customers. The process maps also proved to be a good communication tool by describing the ways of working of the different processes. Additionally, they proved to be a good communication tool for external parties, such as external customers. From an environmental sustainability perspective, process mapping proved to be a useful tool for communicating environmental practices to both internal and external parties 
in a clearer way. In both case studies, it was observed that, by having a clear way of incorporating environmental practices into the management systems, they could attract customers who were interested in obtaining better solutions from an environmental perspective.

Process mapping proved to have potential to be used as a basis for other tools for taking measurements during the process improvement step. The determination of performance indicators for each process suggests that there is potential for setting measurements to monitor environmental development based on the different steps in the processes. This confirms the suggestions made by Ghose et al. (2009). Process mapping provided an overview of the processes within each company and provided a way to determine where it was possible to include environmental efforts and how to measure them. In the Haulier case, process mapping worked to identify areas where environmental aspects could be linked with the practices of the company. In the Forwarder case, process mapping enabled the placement of measurements of environmental aspects within each process. These measurements were designed in line with the environmental goals set by the company's management and provided a basis for determining what aspects needed to be monitored and controlled in order to achieve their goals. However, this monitoring was not actually performed in either case. The difference in the use of these tools was explained by the gap in the degree of implementation achieved in each case. Therefore, it is fair to say that the benefits attainable with this tool depend upon the degree of implementation of process management achieved within an organisation.

Measurements allow organisations to make decisions based on facts (Bergman and Klefsjö, 2010). Consequently, measuring environmental aspects would allow organisations to make more environmentally conscious decisions. When measuring a process, it is important to measure the right things at the right time, and the measurements should provide relevant information about the process. Therefore, it is necessary to determine when and how to perform these measurements in the process.

The next process management tool that could support the enhancement of environmental sustainability is process control. After the setting of goals, targets and measurements, they need to be monitored and controlled. Control tools, such as those included in statistical quality control, have potential for monitoring and controlling environmental aspects. An example is the use of control charts, which provide the ability to monitor a process and identify indicators of potential problems. However, in the case study, it was not possible to confirm this suggestion.

\subsection{Potential benefits of process management in freight transport companies}

Process management provides a means for logistics companies to achieve a systemic view of their operations and a way to measure performance, including environmental sustainability (Garvare and Isaksson, 2001; Isaksson and Garvare, 2003; Näslund, 2002). In other fields, this methodology has enabled performance measurements at different levels by providing indicators and measurements of the different processes within an organisation (e.g. Ghose et al., 2009; Houy et al., 2010; Recker et al., 2010). By measuring performance, it is possible to monitor processes in a more accurate way, control them and make decisions based on facts (Bergman and Klefsjö, 2010). These measurements, together with the systemic view, are a way to increase efficiency and effectiveness at both an operational and economic level and can even provide a way to increase effectiveness and efficiency of the environmental aspects by incorporating environmental parameters, targets and practices into the processes (Navarro and Cronemyr, 2018).

When generating strategy for an organisation, process management can be an ally by establishing measures for each process that allow specific goals to be achieved (e.g. Palmberg, 2009; Cronemyr and Danielsson, 2013). Measurements, goals and strategy can all be connected to environmental aspects when an organisation is interested in enhancing its environmental 
sustainability. Then, process management will enable the monitoring and controlling of environmental performance.

If processes are designed correctly, with teams and process owners assigned to them, it is possible to eliminate activities that do not add value for the customer and do not support other activities that do add such value (Cronemyr, 2007). This results in the liberation of human, time and economic resources. This liberation of resources can enhance the flexibility of an organisation. Furthermore, a process orientation can support the implementation of environmental management systems, such as ISO 14000. However, this process orientation might be created by the use of ISO 9000 and not only by the use of process management (e.g. Poksinska et al., 2003; Casells et al., 2012; Cosimato and Troisi, 2015; Navarro and Cronemyr, 2018). Moreover, the implementation of process management, a methodology that is completely process oriented, could support the implementation of environmental management systems and even facilitate the enhancement of environmental sustainability (Cassels et al., 2012; Navarro and Cronemyr, 2018).

Due to its systematic and structural principle, process management strengthens the structures within organisations (Paim et al., 2008; Palmberg, 2009; Bergman and Klefsjö, 2010). However, this structure manifests not only at a functional level but even at a workflow level. By having this clear structure, it is easier to determine the roles needed to fulfil customers' requirements. While functional managers are responsible for resource development and allocation, process owners and process teams are responsible for the design, development, improvement and control of the processes (DeToro and McCabe, 1997; Lee and Dale, 1998; Biazzo and Bernardi, 2003; Palmberg, 2009; DaSilva et al., 2012). A clear structure and a process view also allow the development of clear and well-established goals. Hence, functional managers do not have to deal with environmental constraints when allocating resources.

\subsection{Potential challenges of process management in freight transport companies}

When process management emerged, one of its main purposes was to create economic benefits for the companies that used it. This is still the case and represents a challenge when process management in employed to enhance environmental sustainability (Houy et al., 2010; Navarro and Cronemyr, 2018). Customers and organisations in general give priority to the economic sustainability of their products and services, instead of to the effects they have on the environment (Houy et al., 2010). This fact creates an obstacle when making decisions that strive to fulfil environmental initiatives.

Another challenge I found was the lack of knowledge and competence necessary for the overall introduction and implementation of process management in the case companies. This lack of knowledge and competence affected the degree to which the companies could use process management and how far up the implementation ladder (Cronemyr and Danielsson, 2013) they could climb. Other researchers have also encountered this challenge when using process management for an environmental purpose (e.g. Houy et al., 2010). I even found this obstacle in literature examining situations where the use of process management to enhance sustainability proved to be a novel area, with limited research and empirical studies that could guide the use of the methodology towards the enhancement of environmental sustainability.

The structure and systematic perspective that process management incorporates into an organisation can also represent a challenge because they might decrease the flexibility of a company (Benner and Tushman, 2003; Benner and Tushman, 2015). Process management might be harmful for some organisations due to affecting their ability to adapt to changing contexts, such as organisations in business sectors that require high levels of innovation (Benner and Tushman, 2003; Benner and Tushman, 2015). The freight transport business 
sector is highly competitive, with technologies and techniques constantly emerging in order to meet customer requirements and even environmental sustainability. Therefore, the use of process management could affect the ability of companies in this business sector to adapt to the new technologies and techniques.

Resistance to change is another challenge that is present when incorporating process management into an organisation. However, it is not uncommon to face this challenge when dealing with organisational changes, and implementing changes to enhance sustainability is not an exception (Lozano, 2013). Process management requires a change in how we view an organisation in order to include a process orientation and not an exclusive focus on the functions.

When implementing process management, there is a risk of having underdeveloped management systems when the implementation is not carried out in a stepwise matter and in the right order (Cronemyr and Danielsson, 2013). This was confirmed in the Haulier case study, where the company's underdeveloped processes represented a hurdle to achieving the successful implementation of the higher steps in the maturity model.

\subsection{Process management adaptations for enhancing environmental sustainability}

In order to talk about the adaptation of process management methodology to enhance environmental sustainability for road freight transport companies, I consider it appropriate to refer to each of the current challenges.

Resistance to change might be targeted by ensuring strong management commitment. Management should communicate the decision to incorporate process management into the organisation and clearly express the need for this change. Managers should also motivate employees to engage in the change and designate roles for each process. The implementation of process roles, specifically process teams, might give employees a sense of belonging and even ownership. When implementing process management, the process teams are responsible for the design, management, monitoring, control and improvement of their process. However, all employees and even external parties should be able to identify problems and suggest the development of improvements (Cronemyr and Danielsson, 2013). This involvement of all parties can reduce the resistance to change. Furthermore, resistance to change can stem from insecurity due to a lack of competence for its implementation. Therefore, management and functional managers within an organisation should ensure that training is given to those who need it, and especially process owners and process teams.

This training should even reduce the lack of knowledge and competence that might affect the implementation of process management. Furthermore, the use of workshops led by topical experts in the areas of process management and green logistics proved to be effective in facilitating the introduction of process management into the freight transport companies.

Another adaptation to consider relates to the measurements performed within the processes. The principles of process orientation and customer focus in process management can support the striving towards achieving environmental requirements. Houy et al. (2014) mention that, since process management enables the different activities of a company to be catalogued within different processes, it could be possible to include environmental goals and measurements for each process step. This would allow the monitoring and controlling of performance from an environmental perspective (Ghose et al., 2009). These measurements would be based on previously established goals connected to the strategic targets for the companies' environmental practices. The development of these types of goals was achieved in both case companies and proved to have potential to become a way of monitoring the performance of each company from an environmental perspective. 
In terms of the relevance of the information provided by the measurements to an organisation, it is important to use the principle of customer focus in process management methodology. Customers might not be actively asking for an enhancement of the environmental sustainability of a company, but society is. A way to determine the right measurements could be to base an organisation's environmental strategy upon the environmental scenario where the company wants to be. In Sweden, for example, a company could base its environmental strategy on the environmental goals set by the government. They could translate them into what they imply for the organisation and its customers and develop targets that help the organisation to move towards those goals. The targets would then be translated into results for each process, and measurements could be set in place to monitor the attainment of those results. This was particularly observed at Forwarder, where environment-related measurements could be based on the company's environmental goal, which in turn was designed by considering the need for the company to adapt to market goals.

One of the main obstacles to generating solutions with better environmental performance observed in the case study is that transport companies are not always involved in the relationship with the final customer. Instead, they provide a service as a third party to the seller of the products. This represents a difficulty when designing services according to the wishes of the company. As an example, if it would like to connect environmental aspects to the services it offers. This is especially difficult when the seller of goods, customer to the transport company, prioritises cost savings against environmental effects. Having this prioritisation does not necessarily mean that the final customer would not be interested in more environmentally friendly services. This was evidenced by the acquisition of new customers for both Forwarder and Haulier, for whom environmental practices were of interest. When process management is implemented, customer demands and requirements become clearer and are better communicated throughout the organisation by making them the focus of the processes and ensuring that their outputs satisfy customers (e.g. Paim, 2008; Palmberg, 2009; Bergman and Klefsjö, 2010; Cronemyr and Danielsson, 2013). Furthermore, road freight transport companies should consider not only the requirements of customers but also those of society. In the case of Sweden, environmental objectives should be considered when offering services and improving an organisation.

As a way to summarise each of the efforts needed for each step in the implementation of process management to enhance environmental sustainability, I present Table 15. In this table, the process control column is left blank due to the scope of this thesis. 


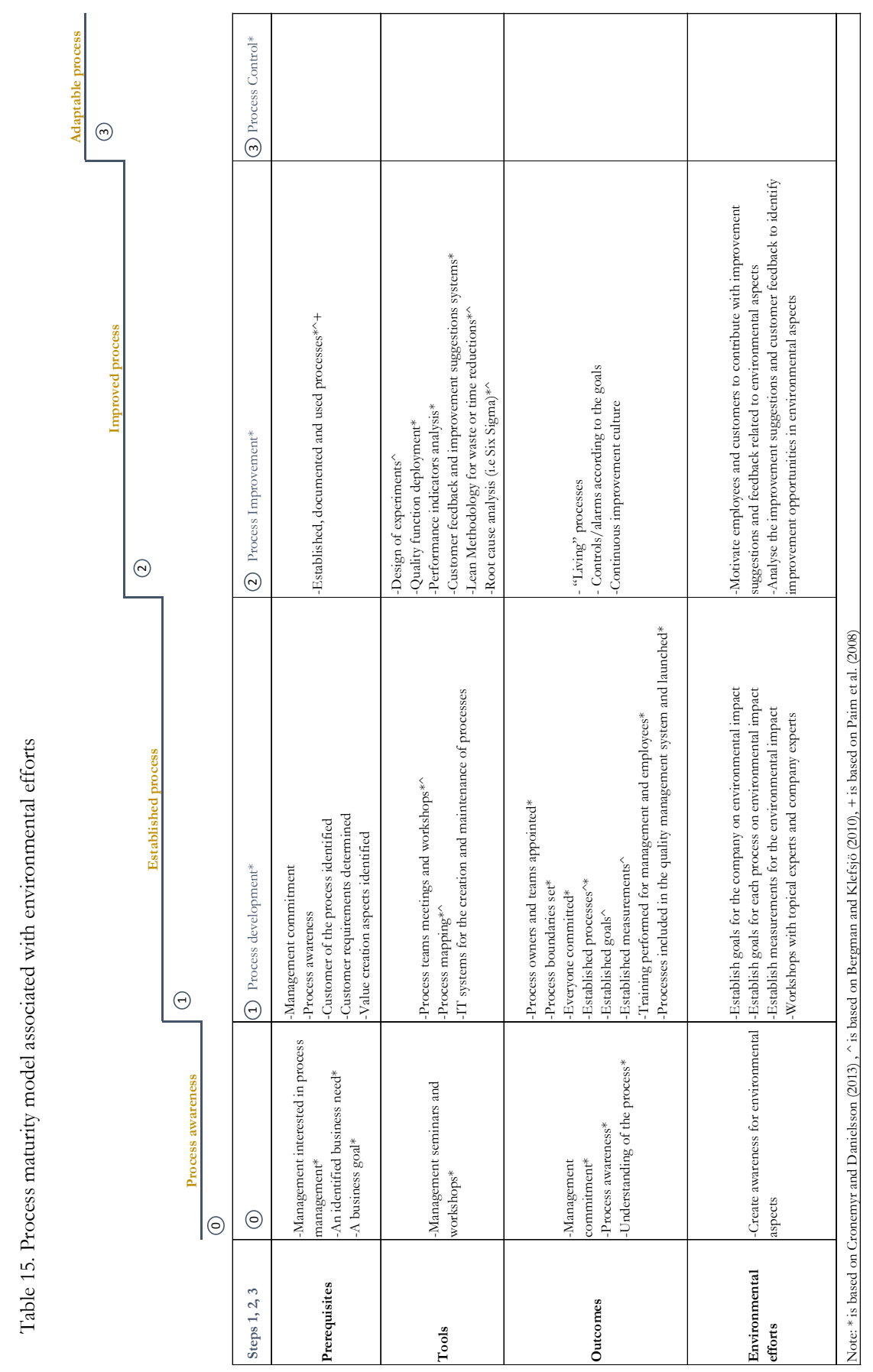




\section{CONCLUSIONS}

This final chapter presents the conclusions of the current study. In it, I answer each of the research questions posed in the Introduction. This chapter also includes a section relating the results of this thesis to existing research in the field. Additionally, I present a section outlining the opportunities for the managerial contributions of this thesis, future research and a brief description of the next steps in my own research. 
I started this thesis with three research questions, which were designed to explore the possibilities of using process management to support the greening of small and medium-sized companies of the road freight transport sector. Therefore, it is only fair to conclude my thesis by referring to each of those questions.

\subsection{Research question 1 \\ Which principles and tools of process management are potentially useful for freight transport companies to enhance environmental sustainability?}

\subsubsection{Principles}

The principles of process orientation, management commitment, standardisation and the involvement of all parties are potentially useful for freight transport companies to enhance their environmental sustainability.

Companies can benefit from using certain principles of process management. Principles such as process orientation and systematisation provide them with a clearer view of their operations. Additionally, the sequence of processes and the connections between them are better understood by everyone in the company when these principles are present. The structure provided by process orientation allows greater coordination between the processes when they can be visualised in a clear and structured way. I also found that, by taking a more systemic view of their organisations, employees and management started to see them as a whole, instead of referring to the functional structures. My conclusion for this principle is that process orientation generates a basis for greater integration between the different processes of a company. It also creates a systemic view for all parties involved.

The focus of freight transport companies needs to continue be on time and costs, since that is where the interest of customers lies. However, I conclude that the customer focus for this business sector needs to expand to include environmental aspects, which are a latent need of both customers and society. This can be supported by the principle of customer focus. In the case companies, current customers do not always require services that are more environmentally sustainable, but this is a latent need. I confirmed that there is an emerging trend of seeing environmental sustainability as a customer requirement from society which impels freight transport companies to adapt their services to be more environmentally sustainable.

I also conclude that management commitment is needed for the implementation of process management and for the enhancement of environmental sustainability. Management should be a guide and motivator before, during and after the methodology is implemented. Management commitment is also required to create a culture within companies in which environmental aspects are relevant and to create awareness of environmental sustainability. It was particularly evident during the improvement phase that management commitment is needed in order to obtain suggestions for improvement that involve environmental aspects.

The principles of structure and systematisation of process management can also support the enhancement of environmental sustainability in the freight transport sector. The holistic view that results from these principles allows better coordination and a clearer structure for the case companies to facilitate their everyday operations and the prioritisation of their work. Additionally, it facilitated both internal and external communication. I found that greater structure and systematisation enables the measurement of environmental and performance aspects.

The final, and by no means least important, principle that I found to be relevant to enhancing sustainability in the freight transport business sector is the involvement of everybody. This principle allows the design of processes based on the ways of working with which employees were most comfortable, while retaining a customer focus. The involvement of everybody also enabled an easier way to design the measures and goals for each process. Overall, involving everyone proved 
to facilitate the implementation of process management methodology. From an environmental perspective, the involvement of all parties facilitated a greater awareness of environmental sustainability and more improvement suggestions connected to it.

\subsubsection{Tools}

Management seminars and workshops, process mapping and root-cause analysis are some of the tools that are useful for the freight transport sector to enhance environmental

Management seminars proved to be an accurate tool for creating awareness of the methodology of process management and the companies' environmental interests. They allowed the designation of suitable processes for each company and the allocation of process owners and teams, which was expected. Another expected result from the management seminars that was confirmed was that they enabled reflections which led to the establishment of environmental, operational and strategic goals for the company. Additionally, and as an unexpected result, the seminars enabled reflections that led to the development of new solutions for customers, and internal policies with reduced environmental impact.

Workshops with management run by topical experts in the areas of process management and green logistics enabled the development of each process and the design of goals and measurements related to environmental aspects for each one. Process mapping was confirmed to be an accurate visualisation tool that facilitated communication with both internal and external parties. From an environmental sustainability perspective, process mapping also proved to be a useful tool for communicating environmental practices to both internal and external parties in a clearer way. This tool increased the satisfaction of current customers and attracted new customers to both companies, by demonstrating that the structure of the company included environmental practices.

I conclude that measuring environmental aspects using performance indicators would allow organisations to make more environmentally conscious decisions; additionally, linking these measurements to specific processes enables the setting of responsibilities that facilitate the monitoring of performance. Additionally, the implementation of customer feedback and improvement suggestions systems would provide the process teams and owners with the necessary data to identify problems and develop solutions. Additionally, I conclude that the gathering of customer feedback using a proactive approach increases the amount of feedback that companies can obtain.

The goals, targets and measurements set during the previous steps could be monitored and controlled by using control tools similar to those included in statistical quality control. Specifically, the Forwarder case confirmed that the use of control charts provided the ability to monitor company activities and identify indicators of potential problems. This suggested potential of using control charts for the measurements is related to environmental sustainability. However, neither of the companies actually applied these tools due to resource constraints.

In the overall implementation of process management at Forwarder, the use of IT systems proved able to support the availability, communication and registry of the process maps. In this case, it was also confirmed that IT systems can support the monitoring of processes through the use of performance indicators. 


\section{2. $\quad$ Research question 2}

\section{What benefits and challenges might freight transport companies face when using process management to enhance environmental sustainability?}

\subsubsection{Benefits}

Companies in the freight transport sector can benefit from process management methodology. Some of the possible benefits are better communication, clearer structure and increased customer focus.

My research confirmed that process management provides the means for logistics companies to achieve a systemic view, strengthen their structure and measure their performance, including environmental sustainability. Companies that use process management can develop a clearer and more robust structure. A clear structure and a process view also allow the development of clear and well-established goals.

This methodology proved to have the potential to measure the performance of a company at different levels to monitor its process. This monitoring, together with the systemic view, has the potential to increase efficiency and effectiveness at both an operational and an economic level and can even provide a way to increase the effectiveness and efficiency of the environmental aspects by incorporating environmental parameters, targets and practices into the processes.

My findings confirm that the measurements, goals and strategies of companies can all be connected to environmental aspects when an organisation is interested in enhancing environmental sustainability. In this way, process management enables the monitoring and controlling of environmental performance.

I confirmed that companies can achieve better results in the implementation of process management when the implementation is undertaken in a stepwise matter and with high commitment from management. Companies in the freight transport sector can develop a clearer structure that enables communication both internally and with external parties. By using process management, the liberation of resources can be achieved by reducing or eliminating non-value-adding activities. Furthermore, the use of process management can support the implementation of management systems, such as ISO 9000 and ISO 14000.

\subsubsection{Challenges}

I conclude that companies in the freight transport sector can face certain challenges when implementing process management to enhance environmental sustainability. Some of these challenges are resistance to change and lack of knowledge and competences.

I confirmed that both customers and companies give higher priority to the economic sustainability of their services, instead of the effect they have on the environment. This fact creates an obstacle when making decisions that strive towards implementing environmental initiatives. However, I found that there is potential for economic and environmental aspects to go hand in hand. In both companies, environmental initiatives were useful for enhancing customer satisfaction among existing customers and as a marketing tool for attracting new customers.

Another challenge that I found was a lack of knowledge and competence to enable the overall introduction and implementation of process management in the case companies. This lack of knowledge and competence affected the degree to which the companies could use process management and how far up the implementation ladder they could climb. I confirmed that companies not following the implementation steps in a sequential manner can end up with underdeveloped management systems. 
The structure and systematic view that process management incorporated into the companies had beneficial results, but also represented a challenge. There was a certain limitation in the flexibility of the companies to offer custom-made solutions to their customers. I identified the possibility that process management might affect the ability of companies in the freight transport business sector to adapt to new technologies and techniques.

Resistance to change is another potential challenge to incorporating process management into companies in the freight transport sector. Employees might initially consider the focus on processes to be time consuming and the documentation unnecessary and annoying. This can represent a challenge for management and requires them to make more effort to motivate employees to use process management.

The allocation of resources is another challenge identified during the study. Resources such as time, employees and money are limited in freight transport companies, which affects their allocation for the implementation of process management.

I also conclude that it is challenging for freight transport companies to generate a culture in which the processes are living and used. The designation of process teams consisting of employees who know the processes facilitates the development of processes based on established working routines, as well as the identification of connections that a given process may have with other processes. However, once the processes were established and launched, the majority of employees did not use the developed process maps, nor did they submit suggestions for improvement.

The challenges described here represent a need for the adaptation of process management

\subsection{Research question 3}

\section{How could process management be adapted to enhance environmental sustainability in freight transport companies?}

The identification of the principles of process management in the case study and the results from the implementation confirm many of the existent literature related to process management. Albeit, some adaptations are needed to include the environmental aspects.

To name the required adaptations, I consider it appropriate to refer to each of the identified challenges. Resistance to change might be targeted by ensuring strong commitment from management. Enabling clear communication within the process teams, between process teams and with management might decrease the effects of resistance to change. The implementation of process roles, specifically process teams, gives the involved employees a sense of belonging and even ownership of each of the processes and the overall implementation of the process management methodology, which reduces their resistance to change. During the implementation of process management, it is important to enable the involvement of all employees. For the improvement step of the implementation, the involvement of customers is recommended. This involvement of all parties can also reduce resistance to change.

Furthermore, resistance to change can stem from insecurity due to a lack of the necessary competence for its implementation. Therefore, management and the functional managers within an organisation should ensure that training is given to those that need it, especially process owners and process teams. Training can increase knowledge and competence, and thus facilitate the implementation of process management. Furthermore, my observations and analysis indicate that the use of workshops run by topical experts in the areas of process management and green logistics can be an effective way to facilitate the introduction of process management into freight transport companies.

I mentioned previously that it is challenging for the companies in this business sector to develop processes that are used and living. The support of IT systems with integrated functions for process management might facilitate the collection of suggestions for improvement, the identification of problems and the continual improvement of the processes. 
It can bring employees closer to the processes by enabling a platform where they can visualise the processes and identify opportunities for improvement.

The implementation of process management can be achieved without a complete adaptation of the methodology. However, some adaptations are necessary in order to include the environmental factor. I conclude that this environmental factor can be included in the process maturity model, where the implementation of environmental aspects can be added to each step. The suggested adaptations to the maturity model include ensuring environmental awareness among all employees and the design of environmental goals and measurements. The adaptations for each step can be seen in Table 15 .

\subsection{Theoretical contributions}

From a theoretical perspective, the aim of my thesis was to contribute to two well-established academic disciplines. Firstly, it contributes to logistics by providing a study on the use of a potential methodology enabling freight transport to become more environmentally sustainable. Additionally, I confirmed that environmental sustainability is not a priority for customers in this business sector. However, it is a latent need, and customers are increasingly becoming interested in such aspects when choosing their transport services.

My research constitutes a case study at two medium-sized transport companies which implemented the methodology of process management to different extents. In this case study, I have identified several benefits and challenges that freight transport companies may face when using this methodology. Additionally, I presented findings from the implementation that are worthy of consideration by companies interested in applying this methodology; for example, I confirmed the need to implement the methodology in a stepwise manner.

Secondly, I aim to contribute to quality management by presenting a study on the implementation of process management in a context where its application has not been registered in the literature, the road freight transport sector. Additionally, I contribute to research on process management by providing potential adaptations that enable the methodology to enhance environmental sustainability. The results of my research include the potential challenges that companies in the freight transport sector may face when implementing this methodology. Furthermore, I have presented some of the adaptations that are required for the methodology to enhance environmental sustainability. An example of this adaptations can be seen in Table 15, where I linked each of the steps in the process management maturity model to the efforts required for it to enhance environmental sustainability.

My intention with this thesis is also to reposition process management as a methodology that can provide benefits not only to individual companies but also to society by enabling solutions with enhanced environmental performance. I have confirmed that, in the freight transport sector, customers can be interested in environmental aspects even when the need is not explicitly presented. Moreover, this thesis contributes to a mapping of the existing literature on the intersections between the three domains presented in Figure 2, and to fill the gap at the centre of the figure.

\subsection{Managerial impact and implications}

The managerial impact of this research lies in the implementation of process management adapted to each of the two case companies. It included the design of process maps and the necessary documents for the process improvement steps. As mentioned in the Analysis and Discussion, these tools provided better communication, clearer structure and a visualisation instrument for both internal and external parties related to the companies. 
The managerial implication of my thesis is the set of tools and principles that SMEs in the freight transport sector can use to enhance both their environmental sustainability and their structure and systematisation.

\subsection{Future research}

My study demonstrated that process management requires certain adaptations to be useful for companies in the road freight transport sector. Challenges such as the lack of knowledge suggest a need for a simplification of this methodology. Companies of the road freight transport business sector experience limited time, human and financial resources. Therefore, a simpler adaptation of the methodology would be more viable for these companies.

Process management is a methodology that looks at organisations as a system. However, organisations are not hermetic and there are other parties that also affect them. Suppliers and customers play important roles in the performance of an organisation. Cooperation with these two parties has been proved beneficial for companies in this business sector (e.g. Martinsen, 2014). Innovation and flexibility are two aspects that tend to improve when an organisation has good relations and collaboration with both suppliers and customers. Companies and customers prioritise economic results over the environmental effects of services and products. By cooperating with their customers, freight transport companies could develop solutions that are still profitable but have reduced environmental impact. Research and practice reveal that, for an initiative to become embedded in a company, it has to be an outspoken customer requirement. Therefore, from a societal perspective, it would be interesting to research how environmental sustainability could turn into a customer requirement, as well as the conditions necessary for customers to appreciate companies with proactive environmental initiatives. This could increase the level of prioritisation that environmental initiatives have in these companies.

Research on process management in combination with various other research disciplines might strengthen the methodology and provide the adaptations required for its success in enhancing environmental sustainability. Principles such as management commitment and the involvement of everyone are strongly connected to organisational theory. This theory has also previously targeted challenges such as resistance to change (e.g. Lozano, 2013). Therefore, research on the purpose of this thesis, connected to organisational theory, might provide suggestions for more accurate adaptations to process management enabling it to enhance environmental sustainability. As mentioned in the conclusions for RQ3, the risk of a decrease in flexibility and adaptability within organisations that apply process management could be diminished through the support of other theories, such as dynamic capabilities. This suggestion is particularly interesting because research on the freight transport sector is familiar with the concept of dynamic capabilities (e.g. Bekalo et al., 2013; Chen et al., 2019), which has been used for improving alliances between supply chain entities and increased performance results.

Moreover, the focus of my study is on SMEs of the road freight transport sector. The implementation of process management on big companies from the business sector should be tested to be able to generalize the conclusions to the business sector.

\subsection{The next step in my research}

$$
\text { "There is no real ending. It's just the place where you stop the story." }
$$

The purpose of my thesis was to explore the possibilities of using process management to support the greening of the freight transport sector. This means that this concluding chapter is a basis for future research on the use of process management to enhance environmental sustainability in the freight transport sector. It is the end of this exploratory story, but the beginning of a new one. 
After developing this thesis, I conclude that there is potential for process management to reposition itself as a methodology within quality management. Additionally, this methodology is useful for the road freight transport sector and can be adapted to enhance environmental methodology. Process management strives for customer satisfaction, and nowadays we should leave behind the idea of the customer being only an external organisation or an internal party. The concept of the customer should also include the dimension of society and, hence, process management should strive towards societal satisfaction. Among the customer requirements of society, I can mention the need to continually enhance environmental sustainability.

Process management has been deeply criticised for its standardisation and systematic approach. The critics refer to the possible rigidity of this methodology when attempting to adapt it to new needs or for achieving innovation. On the other hand, the theory of dynamic capabilities mentions the need for a systematic approach when adapting processes to new needs. Therefore, I consider that the use of process management with the support of dynamic capability theory could provide the methodology with a way to rapidly adapt to changes. This union could increase the flexibility of process management, enabling it to be used in a rapidly changing environment. Hence, the freight transport sector could benefit from using this methodology, since the new technologies that are emerging every day in the business sector require managerial support to ensure their successful implementation. Process management has potential, but the methodology needs to adapt to new requirements and to the needs of the business sector. The requirement for flexibility, fast adaptation and innovation is paramount.

Therefore, the next step in my research is to explore the potential for merging dynamic capabilities and process management in order to give the methodology greater flexibility and adaptability.

\subsection{Final reflections}

Based on my observations and the findings of this study, I suggest that proactive and environmentally ambitious companies, such as Haulier and Forwarder can have a faster environmental development by testing new methods for their managerial approaches, such as process management. These two companies are willing to be pioneers even when there is an associated cost, they could be leading a path for other companies to follow in the efforts towards becoming more environmentally sustainable. In my research, these two companies have been crucial for developing change. 
REFERENCES

This chapter lists the references used in the thesis. 
Aagaard Nielsen, K. and Svensson, L. 2006. Action and interactive research-Beyond practice and theory. Shaker Publishing. The Netherlands

Ahire, S.L and Dreyfus, P. 2000. The impact of design management and process management on quality: An empirical investigation. Journal of Operations Management. 18, pp.549-575.

Ammenberg, J. 2018. Environmental management: environmental and sustainability work on companies and other organisations (In Swedish: Miljömanagement: miljö- och hållbarhetsarbete i företag och andra organisationer). Studentlitteratur AB. Lund.

Andersson, D.; Dubois, A.; Eriksson, V.; Hulthén, K. and Holma, A.M. 2019. The transport service triad: A key unit of analysis. Journal of Business \& Industrial Marketing. 34(1), pp. 253-266.

Anderson, J.C.; Rungtusanatham, M. and Schroeder, R.G. 1994. A theory of quality management underlying the Deming Management Method. The Academy of Management Review. 19, pp. 472-509.

Aronsson, H., and Brodin, M. H. 2006. The environmental impact of changing logistics structures. International Journal of Logistics Management 17 (3) pp. 394-415.

Azevedo, S.G., H. Carvalho, S. Duarte, and V. Cruz-Machado. 2012. Influence of green and lean upstream supply chain management practices on business sustainability. IEEE Transactions on Engineering Management. 59 (4), pp. 753765.

Bawden, R. and Zuber-Skerritt, O. 2002. The concept of process management. The Learning Organisation. 9(3), pp. 132138.

Bellah, J., P.J. Zelbst, and K.W. Green. 2013. Unique TQM practices and logistics performance. International Journal of Productivity and Quality Management. 12 (1), pp. 61-76.

Benner, M.J. and Tushman, M.L. 2003. Exploitation, exploration, and process management: The productivity dilemma revisited. Academy of Management Review. 28 (2), pp. 238-256.

Bergman, B. and Klefsjö, B. 2010. Quality from customer needs to customer satisfaction. Studentlitteratur AB. Lund.

Björklund, M.; Abrahamsson, M. and Johansson, H. 2017. Critical factors for viable business models for urban consolidation centers. Research in Transportation Economics.64, pp. 36-47.

Bou-Llusar J.C.; Escrig-Tena, A.B.; Roca-Puig, V. and Beltrán-Martín, I. 2009. An empirical assessment of the EFQM Excellence Model: Evaluation as a TQM framework relative to the MBNQA Model. Journal of Operations Management. 27(1), pp. 1-22.

Božić, D.; Stanković, R. and Rogić, K. 2014. Possibility of applying business process management methodology in logistic processes optimization. Transport Logistics Review. 26 (6), pp. 507-516.

Brah, S.A., and H.Y. Lim. 2006. The effects of technology and TQM on the performance of logistics companies." International Journal of Physical Distribution \& Logistics Management. 36 (3), 192-209.

Brekalo, L.; Albers, S.; and Delfmann, W. 2013. Logistics alliance management capabilities: Where are they? International Journal of Physical Distribution and Logistics Management. 43 (7), 529-543.

Brundtland, H. 1987. Our common future: The world commission on environment and development. United Nations. Oxford University Press.

Bryman, A. and Bell, E. 2011. Business research methods. $3^{\text {rd }}$ ed. Oxford University Press. New York, USA.

Carvalho, H., Duarte, S., and Machado, V.C. 2011. "Lean, agile, resilient and green: divergencies and synergies". International Journal of Lean Six Sigma. 2 (2), pp.151-179.

Cassells, S., K.V. Lewis, and A. Findlater. 2012. An exploration of ISO14001 uptake by New Zealand firms. International Journal of Law and Management. 54 (5), 345-363.

Chang, J.F. (2006). Business process management systems: Strategy and implementation. Auerbach Publications. New York, USA

Chen, I.S.N.; Fung, P.K.O. and Yuen, S.S.M. 2019. Dynamic capabilities of logistics service providers: Antecedents and performance implications. Asia Pacific Journal of Marketing and Logistics. 31 (4), pp. 1058-1075.

Colicchia, C., G. Marchet, M. Melacini and S. Perotti. 2013. Building environmental sustainability: Empirical evidence from logistics service providers. Journal of Cleaner Production. 59, 197-209.

Commission of the European Communities. 2001. White Paper: European transport policy for 2010: Time to decide. Brussels.

Cosimato, S. and O. Troisi. 2015. Green supply chain management.” Journal of Manufacturing Technology Management. 27 (2), 256-276.

CSCMP. 2019. Council of Supply Chain Management Professionals: Supply chain management definitions and glossary. Available at:

https://cscmp.org/CSCMP/Educate/SCM_Definitions_and_Glossary_of_Terms/CSCMP/Educate/SCM_Defin itions_and_Glossary_of_Terms.aspx?hkey=60879588-f65f-4ab5-8c4b-6878815ef921 (Accessed:12 August 2019)

Crosby, P.B. 1979. Quality is free: The art of making quality certain. New York: New American Library.

Cronemyr, P. 2007. Six Sigma Management: Action research with some contributions to theories and methods. Division of Quality Sciences. Chalmers University of Technology. Gothenburg, Sweden. 
Cronemyr, P. and Danielsson, M. 2013 "Process Management 1-2-3 - A Maturity Model and Diagnostics Tool”, Total Quality Management \& Business Excellence, 24 (7-8), pp. 933-944.

da Silva, L.A.; Damian, I.P.M. and de Pádua, S.I.D. 2012. Process management tasks and barriers: Functional to processes approach. Business Process Management Journal. 18 (5), pp.762-776.

Dahlgaard-Park, S.M. 2011. The quality movement: Where are you going? Total Quality Management and Business Excellence. 22 (5), 493-516.

Davenport, T.H. 1993. Process innovation: Reengineering work through information technology. Harvard Business School Press [for] Ernst \& Young, Center for Information Technology and Strategy. Boston.

de Bruin T., Doebeli G. 2015. An organizational approach to BPM: The experience of an Australian transport provider. In: vom Brocke J., Rosemann M. (eds) Handbook on business process management 2. International Handbooks on Information Systems. Springer, Berlin, Heidelberg.

Deleryd M. and Fundin A. 2015. The fifth generation of quality concept: From customer to societal satisfaction. Presented at The World Quality Forum of International Academy for Quality (LAQ), Budapest. 2015-10-27.

Deming, W.E. 1986. Out of the crisis. Massachusetts Institute of Technology, Center for Advanced Engineering Study, Cambridge MA.

Deming, W.E. 1993. The new economics for industry, government, education. Massachusetts Institute of Technology, Centre for Advanced Engineering Study, Cambridge, MA.

De'Toro, I. and McCabe, T. 1997. How to stay flexible and elude fads. Quality Progress. 30

(3), pp. 55-60.

Doggett. A.M. 2005. Root cause analysis: A framework for tool selection. Quality Management Journal. 12 (4), pp. 34-45.

Ellström, P. 2008. Knowledge creation through interactive research: A learning perspective. In The proceedings from: The European Conference on Educational Research (ECER), Gothenburg, September 10-12-2008.

European Commission. 2014. A policy framework for climate and energy in the period from 2020 to 2030. Brussels.

Evangelista, P., Huge-Brodin, M., Isaksson, K. and Sweeney, E. 2013. Purchasing green transport and logistics services: Implications from the environmental sustainability attitude of 3PLs. In Information Resources Management Association (ed.), Sustainable practices: Concepts, methodologies, tools, and applications. Vol. 1, IGI Global, pp. 86-102.

Evangelista, P. and Sweeney, E. 2014. Information and communication technology adoption in the Italian road freight haulage industry. International Journal of Logistics Systems and Management. 19 (3), pp. 261-282.

Evangelista, P.; Colicchia, C. and Creazza, A. 2017. Is environmental sustainability a strategic priority for logistics service providers? Journal of Environmental Management. 198, pp. 353-362.

Flynn, B.B.; Schroeder, R.G. and Sakakibara, S. 1995. The impact of quality management practices on performance and competitive advantage. Decision Sciences. 26, pp. 659-691.

Fossil Free Sweden 2018. Roadmap for fossil free competitiveness: A summary of roadmaps from Swedish Business Sectors. http:// fossilfritt-sverige.se/wp-content/uploads/2018/02/roadmap_for_fossil_free_competitiveness_klar .pdf. Accessed: 26 September 2019.

Foster, M. 1972. An introduction to the theory and practice of action research in work organisations. Human Relations. 25 (6), pp. 529-556.

Foy, G. 1990. Economic sustainability and the preservation of environmental assets. Environmental Management. 14 (6), pp. $771-778$.

Garvare, R., and R. Isaksson. 2001. Sustainable development: Extending the scope of business excellence models. Measuring Business Excellence. 5 (3), pp. 11-15.

Ghose, A., K. Hoesch-Klohe, L. Hinsche, and L. Le. 2009. Green business process management: A research agenda. Australaisian Journal of Information Systems. 16 (2), pp.103-117.

Goodland, R. 1995. The concept of environmental sustainability. Annual Review of Ecology and Systematics. 26, pp. 1-24.

Green, K.W.; Inman, R.A.; Sower, V.E and Zelbst, P.J. 2019. Impact of JIT, TQM and green supply chain practices on environmental sustainability. Journal of Manufacturing Technology Management. 30(1), pp. 26-47.

Guba, E.G. and Lincoln, Y.S. 1994. "The Context of Emergent Paradigm Research”, in Y.S. Lincoln (ed.), Organisation Theory and Inquiry: The Paradigm Revolution. Beverly Hills, CA: Sage.

Gummesson, E. 2000. Qualitative methods in management research. 2nd ed. Newbury Park: Sage. (1st ed. 1991).

Hall, J. and Wagner, M. 2012. Integrating sustainability into firms' processes: Performance effects and the moderating role of business models and innovation. Business Strategy and the Environment. 25, pp. 183-196.

Halldórsson, A. and Kovács, G. 2010. The sustainable agenda and energy efficiency: Logistics solutions and supply chains in times of climate change. International Journal of Physical Distribution and Logistics Management. 40 (1), pp. 5-13.

Hammer, M. 2007. The process audit. Harvard Business Review. 85 (4), pp. 111-123.

Hammer, M. and Champy, J. 1993. Reengineering the corporation: A manifesto for business revolution. New York: Harper Business. 
Hansson, A. 2003. Praktiskt taget. Aktionsforskning som teori och praktik I spåren efter LOM. Doctoral Thesis., Halmstad: Halmstad högskola.

Harrington, H. 1991. Business process improvement: The breakthrough strategy for total quality, productivity, and competitiveness. McGraw-Hill. New York.

Hellsten, U. \& Klefsjö, B. 2000. TQM as a management system consisting of values, techniques and tools. The TQM Magazine. 12(4), pp. 238-244.

Hellström, A.; Lifvergren, S. and Quist, J. 2010. Process management in healthcare: Investigating why it's easier said than done. Journal of Manufacturing Technology Management. 21 (4), pp. 499-511.

Hellström, A. and Eriksson, H. 2008. Are you viewing, mapping or managing your processes? The TQM Journal. 20 (2), pp. 166-174.

Hellström, A. and Eriksson, H. 2013. Among fumblers, talkers, mappers and organisers: Four applications of process orientation. Total Quality Management \& Business Excellence. 24 (5-6), pp. 733-751.

Herr, K.G. and Andersson, G. 2015. The action research dissertation: A guide for students and faculty. 2nd Ed. Sage. Los Angeles, California.

Hervani, A.A., M.M. Helms, and J. Sarkis. 2005. Performance measurement for green supply chain management. Benchmarking: An International Journal. 12 (4), pp. 330-353.

Hinterhuber, H.H. 1995. Business process management: The European approach. Business Change \& Re-engineering. 2 (4), pp. 63-73.

Houy, C., Reiter, M., Fettke, P. and Loos, P. 2010. Towards green BPM: Sustainability and resource efficiency through business process management. In: zur Muehlen, M., Su, J. (eds.) Business process management workshops, BPM 2010 International Workshops and Education Track. Hoboken, NJ, USA, September 2010, Revised Selected Papers, Springer, Heidelberg, Germany, pp. 511-520.

Huge-Brodin, M. and Cronemyr, P. 2019. Co-creation knowledge for more sustainable freight transports. Presented at $6^{\text {th }}$ International EUROMA Sustainable Operations and Supply Chains Forum, Gothenburg 2019.

Isaksson, K. 2012. Logistics service providers going green: Insights from the Swedish market. PhD diss., Linköping University.

Isaksson, R. 2006. Total quality management for sustainable development: Process based system models. Business Process Management Journal. 12 (5), pp. 632-645.

Isaksson, R. and R. Garvare. 2003. Measuring sustainable development using process models." Managerial Auditing Journal. 18 (8), 649.

Johansson, H. 2018. Trafikverket. Minskade utsläpp men snabbare takt krävs för att nå klimatmål (In Swedish). Available at: https://www.trafikverket.se/contentassets/07f80f01d92144eebf1a01fcb60ac923/ pm_vagtrafikens_utslapp_180225.pdf. (Accessed: 15 May 2018)

Kano, N. 2001. Life cycle and creation of attractive quality. 4th International QMOD Conference Quality Management and Organisational Development Proceedings, Linköpings Universitet, Sweden.

Klefsjö, B.; Bergquist, B. and Edgeman, R. 2006. Six sigma and Total Quality Management: Different day, same soup? International Journal of Six Sigma and Competitive Advantage. 2 (2), pp. 162-178.

Kohlbacher, M. and Gruenwald, S. 2011. Process orientation: Conceptualization and measurement. Business Process Management Journal. 17 (2), pp. 267-283.

Kohn, C. and Huge-Brodin, M. 2008. Centralised distribution systems and the environment: How increased transport work can decrease the environmental impact of logistics. International Journal of Logistics. 11 (3), pp. 229-245.

Krajcsák, Z. 2019. Leadership strategies for enhancing employee commitment in TQM. Journal of Management Development. 38 (6), pp. 455-463.

Kroslid, D. 1999. In search for quality management: Rethinking and reinterpreting. Division of Quality Technology and Management. Linköping University. Linköping, Sweden.

Lee, R.G. and Dale, B.G. 1998. Business process management: A review and evaluation. Business Process Management Journal. 4 (3), pp. 214-225.

Lewin, K. 1946. Action research and minority problems. Journal of Social Issues. 2 (4), 34-46

Lewin, K. 1947. Group decisions and social change. In Reading in social psychology, edited by T. M. Newcomb and E. L. Hartley. New York: Henry Holt and Company. 1(2), pp. 143-153.

Lieb, K.J., Lieb, R.C., 2010. Environmental sustainability in the third-party logistics (3PL) industry. International Journal of Physical Distribution \& Logistics. Management. 40 (7), 524-533.

Lockamy III, A. \& McCormack, K. 2004. The development of a supply chain management process maturity model using the concepts of business process orientation. Supply Chain Management: An international Journal. 9 (4), pp. 272278.

Maack, C. 2012. Logistics service providers' environmental management. Department of Management and Engineering. Linköpings University. 
Mangan, J., and M. Christopher. 2005. Management development and the supply chain manager of the future. International Journal of Logistics Management. 16 (2): 178-191.

Márquez-Ramos, L. 2015. "The relationship between trade and sustainable transport: A quantitative assessment with indicators of the importance of environmental performance and agglomeration externalities”, Ecological Indicators. Elsevier Ltd, Vol.52, pp. 170-183.

Martinsen, U. and Huge-Brodin, M. 2014. "Environmental practices as offerings and requirements on the logistics market", Logistics Research, 7:115.

McCormack, K. and Johnson, W.C. 2001. Business process orientation: gaining the e-business competitive advantage. CRC Press LLC. Washington D.C.

McCormack, K. 2007. Business Process Maturity. BookSurge. Lexington, KY.

McKinnon, A. 2010. Green logistics: Improving the environmental sustainability of logistics. Kogan Page. London; Philadelphia

McKinnon, A.C. 2015. Environmental sustainability: A new priority for logistics managers. In Green logistics: Improving the environmental sustainability of logistics, edited by A. McKinnon, M. Browne, A. Whiteing, and M. Piecyk, 3-30. London: Kogan Page.

McKinnon, A., Browne, M., Whiteing, A. and Piecyk, M. 2015. Green logistics: Improving the environmental sustainability of logistics. London: Kogan Page.

McKinnon, A. C. and M. I. Piecyk. 2009. Measurement of $\mathrm{CO}_{2}$ emissions from road freight transport: A review of UK experience. Energy Policy. 37 (10), 3733-3742.

Merriam, S.B. 1988. Case study research in education: A qualitative approach. JosseyBass:, San Francisco, CA.

Mi Dahlgaard- Park, S. and Zink, K. 2007. From total quality management to corporate sustainability based on a stakeholder management. Journal of Management History. 13 (4), pp. 394-401.

Miles, M.B. and Huberman, A.M. 1994. An Expanded Sourcebook: Qualitative Data Analysis. Second Edition. Sage. California.

Mitra, S. 2014. A framework for research on green supply chain management. Supply Chain Forum: An International Journal. 15 (1), pp. 34-51.

Mulhall, A. (2003). In the field: Notes on observation in qualitative research. Journal of Advanced Nursing. 41, pp. 306313.

Navarro, P. and Cronemyr, P. 2018. Applying quality methods for achieving environmental sustainability in the freight transport sector: Reviewing Process Management and Lean. Presented at 21 $1^{\text {st }}$ QMOD Conference, Cardiff 2018.

Navarro, P.; Cronemyr, P. and Huge-Brodin, M. 2018a. Greening logistics by introducing process management: A viable tool for freight transport companies going green. Supply Chain Forum: An International Journal. July 2018 Doi: 10.1080/16258312.2018.1486141

Navarro, P.; Cronemyr, P.; Huge-Brodin, M. 2018b. How to implement green logistics: Using improvement processes for increasing environmental initiatives in freight transport companies. 21st International Conference in Excellence in Services. Paris, France.

Nilsson, L. 1999. Process orientation in product development. PhD diss. Division of Quality Technology and Management. Linköpings University. Thesis No. 772. Linköping, Sweden

Näslund, D. 2002. Logistics for managing and improving processes. Supply Chain Forum: An International Journal. 3 (2), 48-57.

Oakland, J.S. 1998. Total Quality Management: Text with Cases. 4th edn. New York: McGraw-Hill.

Oskarsson, B.; Aronsson, H. and Ekdahl, B. (2003). Modern Logistik- för ökad lönsamhet, 4th edn. Stockholm: Liber.

Paim, R., Caulliraux, H.M., Cardoso, R. (2008). Process management tasks: A conceptual and practical view. Business Process Management Journal. 14 (5), 694-723.

Palmberg, K. 2010. Experiences of implementing process management: A multiple-case study. Business Process Management Journal. 16 (1), pp. 98-113.

Palmberg, K. 2009. Exploring process management: Are there any widespread models and definitions? The TQM Journal. 21 (2), pp. 203-215.

Poksinska, B., J.J. Dahlgaard, and J.A. Eklund. 2003. Implementing ISO 14000 in Sweden: Motives, benefits and comparisons with ISO 9000. International Journal of Quality \& Reliability Management. 20 (5), pp. 585-606.

Piecyk, M. 2015. Green logistics, sustainable development and corporate social responsibility. In: Green logistics: Improving the environmental sustainability of logistics. edited by A. McKinnon, S. Cullinane, A. Whiteing and M. Browne. Kogan Page, $3^{\text {rd }}$ Ed., pp. 107-122. London

Rapoport, R. 1970. Three dilemmas in action research. Human Relations. 23 (6), pp. 499-513.

Recker, J., Rosemann, M. and Gohar, E.R. 2010. Towards green BPM: Sustainability and resource efficiency through business process management. In: zur Muehlen, M., Su, J. (eds.) Business process management workshops, BPM 2010 International Workshops and Education Track. Hoboken, NJ, USA, September 2010, Revised Selected Papers, Springer, Heidelberg, Germany, pp. 511-520. 
Richardson, B.C. 2005. Sustainable transport: Analysis frameworks. Journal of Transport Geography. 13 (1 SPEC. ISS.), 29-39.

Rohloff, M. 2009. An approach to assess the implementation of business process management in enterprises. Conference: 17th European Conference on Information Systems, ECIS 2009. Verona, Italy.

Rohloff, M. 2011. Advances in business process management implementation based on a maturity assessment and best practice exchange. Information Systems and e-Business Management. 9 (3), pp. 383-403.

Sallnäs, U. 2016. Coordination to manage dependencies between logistics service providers and shippers: An environmental perspective. International Journal of Physical Distribution \& Logistics Management. 46 (3), 316-340. doi:10.1108/IJPDLM-06-2014-0143.

Sanford, N. 1970. Whatever happened to action? Journal of Social Issues. 26 (4), pp. 3-23.

Sarkis, J., Meade, L.M. and Talluri, S. 2004. E-logistics and the natural environment. Supply Chain Management. 9 (4), 303-312.

Savino, M. M. and Mazza, A. 2016. Assessing product sustainability measurement within quality management systems: a case study in automotive industry. International Journal of Productivity and Quality Management. 18(2), pp.258-278.

Sawhney, R., Teparakul, P. Bagchi, A. and Li, X. 2007. "En-Lean: a framework to align lean and green manufacturing in the metal cutting supply chain," International Journal Enterprise Network. Management. 1(3), pp. 238-260.

SCB. 2018. Emissions of greenhouse gases from international transport by greenhouse gas and activity. Year 1990-2017. Autumn 2018. Responsible Authority: Swedish Environmental Protection Agency. Sweden.

Shewhart, W.A. 1931. Economic control of quality and manufactured product. Van Nostrand, New York.

Shewhart, W.A. 1939. Statistical method from the viewpoint of quality control. Graduate School of the Department of Agriculture, Washington D.C.

SIQ. 2018. Swedish Institute for Quality Management Model Manual. 2018:1. Gothenburg/Stockholm, Sweden.

Siva, V. Gremyr, I and Halldórsson, A. 2018. Organising Sustainability Competencies through Quality Management: Integration or Specialisation. Sustainability. 10(5), pp. 1-14.

Smart Freight Centre. 2016. Barriers for carriers to adopt fuel-saving technologies and measures: Mapping barriers relevant to road freight carriers. Available at: https://www.smartfreightcentre.org/pdf/Barriers-for-Carriers-SFC-2016-FINAL.pdf (Accessed: 19 August 2019)

Smith, K.H. 2012. Reviews: From systematic to narrative LHL Guides at UAB Lister Hill Library of the Health Sciences. Available at: http:/ libguides.lhl.uab.edu/sysrev (Accessed: 20 December 2016).

Soltani, E.; Lai, P; Javadeen, S.R.S. and Gholipour, T.H. 2008. A review of the theory and practice of managing TQM: An integrative framework. Total Quality Management. 19(5), pp. 461-469.

Srivastava, S.K. 2007. Green supply-chain management: A state-of-the-art literature review. International Journal of Management Reviews. 9 (1), 53-80.

Sveriges Åkeriföretag. 2016. Facts about the transport industry (In Swedish. Fakta om Åkerinäringen. https://www.akeri.se/sites/default/files/2018-06/fakta_om_akerinaringen.pdf. (Accessed: 21 September 2019).

Sveriges Åkeriföretag. 2019. About the Swedish Association for Road Transport Companies (In Swedish: om Sveriges åkeriföretag). https://www.akeri.se/sv/sveriges-akeriforetag. (Accessed: 13 September 2019).

Swedish Environmental Protection Agency (2018). Sweden's environmental objectives - An introduction. Available at: http://www.swedishepa.se/Documents/publikationer6400/978-91-620-8820-0.pdf?pid=23427 (Accessed: 18 September 2019).

Trafikanalys. 2016. Godstransporter i Sverige. en nulägeanalys Rapport 2016:7. Stockholm.

Trafikanalys. 2019a. Tunga och lätta lastbilars transporter - fokus urbana miljöer. Rapport 2019:4. Stockholm.

Trafikanalys. 2019b. Styrmedel för tunga miljövänliga lastbilar. Rapport 2019:2. Stockholm.

Tranfield, D., Denyer, D. and Smart, P. 2003. Towards a methodology for developing evidence-informed management knowledge by means of systematic review. British Journal of Management. 14, pp. 207-222.

Triantafyllou, M; Cherrett, T. and Browne, M. 2014. Urban freight consolidation centers: -Case study in the UK retail sector. Transportation Research Record: Journal of the Transportation Research Board. 2411. Doi: 10.3141/2411-05

Vakulenko, Y., Hellström, D. and Hjort, K. 2018. What's in the parcel locker? Exploring customer value in e-commerce last mile delivery. Journal of Business Research. 88, pp. 421-427.

Wehner, J. 2018. Energy efficiency in logistics: An interactive approach to capacity utilisation. Sustainability. 10(6), 1727. DOI: $10.3390 /$ su10061727

Weijers, S., Glöckner, H.-H. and Pieters, R. 2012. Logistic service providers and sustainable physical distribution. Scientific Journal of Logistics. 8 (2), 157-165.

Westlander, G. 1999. Forskarroller $i$ varianter av aktionsforskning. Research report TRITA 1999:24. Royal Institute of Technology. Stockholm.

Westlander, G. 2006. Researcher roles in action research. In: Action and interactive research: Beyond practice and theory, edited by L. Svensson and K. Aagaard-Nielsen, pp. 45-61. Maastricht: Shaker Publishing BV. 
Wheeler, D. 1997. The four possibilities for any process. Quality Digest. Available at: https://www.qualitydigest.com/dec $97 / \mathrm{html} /$ spctool.html. (Accessed: 18 September 2017)

Wolf, C., and Seuring, S. 2010. Environmental impacts as buying criteria for third party logistical services. International Journal of Physical Distribution and Logistics Management. 40 (1), 84-102.

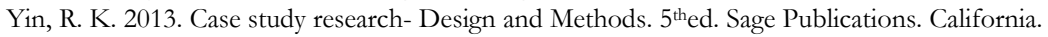

Zink, K. 2007. From total quality management to corporate sustainability based on a stakeholder management.

Journal of Management History. 13 (4), pp. 394-401 
APPENDICES 

INTERVIEW GUIDES 



\section{Interview guides Phase I}

\section{a. Process Management Interview Guide (translated from Swedish)}

Purpose: To gather information for developing a case study in which we can compare the findings in the existing literature with the reality at the case company. This case study is part of a research project based at Linköping University. The case company is a partner in the project. This interview guide was developed based on a previously conducted literature review. Therefore, the purpose of the interviews is to compare the results found in the literature with the reality of the company.

The information provided during this interview will be handled with anonymity. We will analyse all the data gathered from the interviews and presented during the workshop for the company and the joint workshop.

After the interview, you will receive a summary of the information provided by you to be evaluated by you. Changes will be made where necessary; for example, if there are any misunderstandings between what the interviewee said and what the researcher noted.

1. What is your position in the company? What are your work responsibilities?

2. Can you describe your way of working (process) after a customer contacts you for a job? What does the process or activities flow look like? Who performs the activities and who is responsible for them?

3. Is the process documented somewhere/somehow? (Process Map, Manual, Routines, etc.)

4. What input (information / resources) do you need to perform your work?

5. What is the output (result) of your work?

6. Who is/are your customers (internal and external)? What are their needs or requirements?

7. How do you measure and follow up what you do? Do you have performance metrics?

8. When you want to improve something, for example service or process or a way of working, how do you do it?

9. Do you use any improvement tools for your processes? For example: Lean, Six sigma, KPI, VSM.

10. Do you consider that process maps help, in any way, to achieve more sustainable freight transport?

11. Do you have any suggestions for how your processes or process maps could be improved and developed? What would you like your processes to look like in one year's time? 


\section{b. Green Logistics interview guide (translated from Swedish)}

Purpose: To gather information for developing a case study in which we can compare the findings in the existing literature with the reality at the case company. This case study is part of a research project based at Linköping University. The case company is a partner in the project. This interview guide was developed based on a previously conducted literature review. Therefore, the purpose of the interviews is to compare the results found in the literature with the reality of the company.

The information provided during this interview will be handled with anonymity. We will analyse all the data gathered from the interviews and presented during the workshop for the company and the joint workshop.

After the interview, you will receive a summary of the information you have provided to be evaluated by you. Changes will be made where necessary; for example, if there are any misunderstandings between what the interviewee said and what the researcher noted.

1. What is your position in the company? What are your work responsibilities?

2. Can you describe what environmental efforts mean for your work?

3. What demands or requirements do you get from the company and its customers, related to the environment?

4. What do you consider to be the most important aspect for the customer? Is there a relationship between this requirement and the environment?

5. Do you have norms or instructions related to the environment that must be followed?

6. Are there any controls to review environmental impact within the company?

7. Do you have any system for providing services according to the level of environmental impact? (e.g. prices, different cars, intermodal transport, etc.)

8. Does the company cooperate with other companies to offer services to customers and/or reduce environmental impact?

9. Does the customer receive any kind of information about how much the service could affect the environment?

10. How can the company take advantage of involving environmental aspects in its operations?

11. What effects for the company do you think would stem from having greater standardisation? Could standardisation help to achieve sustainable transport from an environmental point of view?

12. Please fill in the following table, which refers to different environmental practices common in transport companies. (The interviewer explains each environmental practice.)

\begin{tabular}{|l|l|l|}
\hline Environmental practice & $\begin{array}{l}\text { Does the company use } \\
\text { it? }\end{array}$ & Reason (environmental/other) \\
\hline Intermodal transport & & \\
\hline Logistics system design & & \\
\hline Transport management & & \\
\hline Vehicle technology & & \\
\hline Behavioural/eco-driving & & \\
\hline Alternative fuel & & \\
\hline $\begin{array}{l}\text { Environmental } \\
\text { Management System }\end{array}$ & & \\
\hline $\begin{array}{l}\text { Choice of } \\
\text { supplier/customer }\end{array}$ & & \\
\hline Emissions data & & \\
\hline
\end{tabular}




\section{Interview guide Phase II (translated from Swedish)}

This interview concerns the second phase of the research project, Improvement processes. At the beginning of the interview, the interviewer gives a reminder of what the project is about and the purpose of it. The analysis and improvement of processes are parts of process management. The following questions concern these issues.

1. How do you usually get information about what the customers think of the company?

2. Does the company do surveys, interviews, focus groups or other activities to collect information about what the customers think about the company?

3. How do you handle customer complains? What do you do when/if you get a customer complain? Do you document them and what you do?

4. How fast do customers get a reply for their complaints?

5. Is it clear who is responsible for handling the complaints?

6. How fast do you solve problems?

7. Is it clear who is responsible for solving the problems?

8. Are the solutions to the problems connected in some way to the processes that concern them? Do you include the solutions in the processes?

9. When there are problems, complaints, suggestions, etc, who is involved in handling them?

10. When the company has faced a problem and solved it, is it communicated to the employees? If so, how?

11. Have you given improvement suggestions for the company?

- Yes: How did you give the suggestion and what happened? Did the company(management) listened to your suggestion? Were there any changes as a product of the suggestion? If you got a response, how fast was it?

- No: Do you know how to give an improvement suggestion?

12. Do you have a procedure for handling problems and improvements? Are they described somewhere?

13. Do you have information/data registered on how the processes/results look are? For example, in:

- Invoicing: how many invoices are paid on time?

- Transports management: how many transports are done on time?

- Services: how satisfied are your customers?

14. Does the company use diagrams, pictures, comparisons, targets, goals, measurements to monitor the results of the company? For example, something that helps the company notice when there is a problem or something that does not go as expected. Which?

15. If there are any improvements to be made, how does the company prioritize which should be fixed first?

16. Does the company conduct surveys, interviews, workshops or other options to gather information about what employees think?

17. Have you carried out improvement projects with root cause analysis at the company (find the problem not the symptoms)? Who? Internal / external help? How has it been documented?

18. Are environmental improvement proposals handled in the same way as other improvement proposals or are they handled in their own way?

19. Where can you see the improvements that have been made? Are they documented in any way? 


\section{Papers}

The papers associated with this thesis have been removed for copyright reasons. For more details about these see:

http://urn.kb.se/resolve?urn=urn:nbn:se:liu:diva-162027 

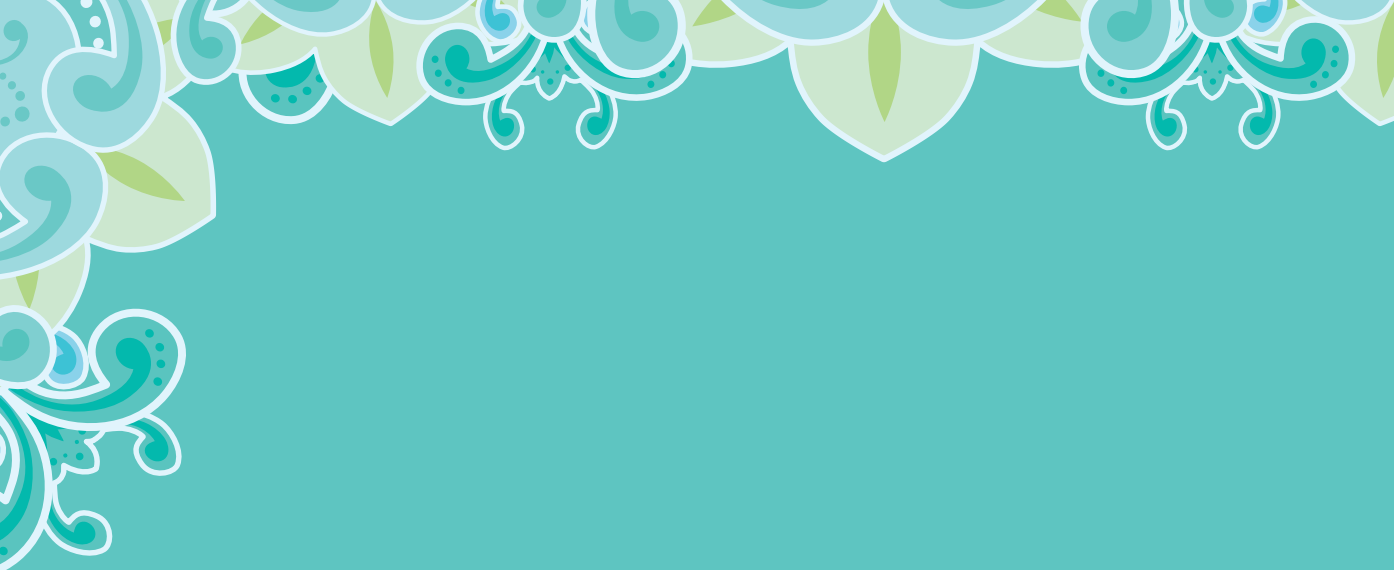

\section{FACULTY OF SCIENCE AND ENGINEERING}

Linköping Studies in Science and Technology, Licentiate thesis No. 1857, 2019 Department of Managemet and Engineering

Linköping University

SE-581 83 Linköping, Sweden

www.liu.se

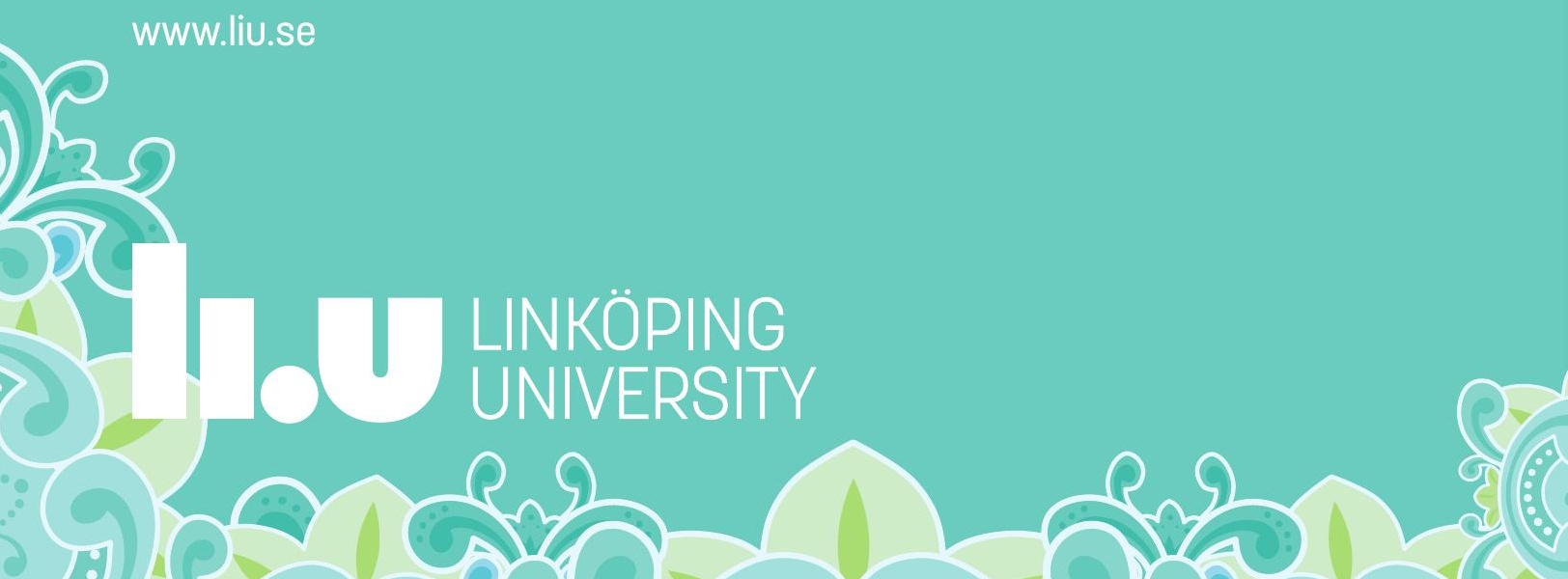

